\author{
UNIVERSIDADE DE SÃO PAULO \\ FFCLRP - DEPARTAMENTO DE BIOLOGIA \\ PROGRAMA DE PÓS-GRADUAÇÃO EM BIOLOGIA COMPARADA
}

Efeitos da condição trófica ambiental na ecologia reprodutiva e desempenho larval em cracas do entremarés

PAULA KASTEN

Tese apresentada à Faculdade de Filosofia, Ciências e Letras de Ribeirão Preto-USP, como parte das exigências para obtenção do título de Doutor em Ciências - Área: Biologia Comparada

RIBEIRÃO PRETO / SP 
UNIVERSIDADE DE SÃO PAULO

FFCLRP - DEPARTAMENTO DE BIOLOGIA

PROGRAMA DE PÓS-GRADUAÇÃO EM BIOLOGIA COMPARADA

\title{
Efeitos da condição trófica ambiental na ecologia reprodutiva e desempenho larval em cracas do entremarés
}

Trophic status effects on the reproductive ecology and larval traits of an intertidal barnacle

\author{
PAULA KASTEN \\ Orientador: Prof. Dr. Augusto Alberto Valero Flores \\ Co-orientador: Prof. Dr. Réjean Tremblay
}

Tese apresentada à Faculdade de Filosofia, Ciências e Letras de Ribeirão Preto-USP, como parte das exigências para obtenção do título de Doutor em Ciências - Área: Biologia Comparada

RIBEIRÃO PRETO / SP 
Autorizo a reprodução e divulgação total ou parcial deste trabalho, por qualquer meio convencional ou eletrônico, para fins de estudo e pesquisa, desde que citada a fonte.

Kasten, Paula

Efeitos da condição trófica ambiental na ecologia reprodutiva e desempenho larval em cracas do entremarés. Ribeirão Preto, 2016.

p. : il. ; cm

Tese de Doutorado, apresentada à Faculdade de Filosofia, Ciências e Letras de Ribeirão Preto/USP. Área de concentração: Biologia Comparada.

Orientador: Flores, Augusto Alberto Valero.

Co-orientador: Tremblay, Réjean

1. efeitos maternos,2. efeitos latentes,3. Chthamalus bisinuatus,4. alimentação,5. qualidade larval 
Nome: Kasten, Paula

Título: Efeitos da condição trófica ambiental na ecologia reprodutiva e desempenho larval em cracas do entremarés.

Tese apresentada à Faculdade de Filosofia, Ciências e Letras de Ribeirão Preto, Universidade de São Paulo para obtenção do título de Doutor em Biologia Comparada

Aprovado em:

Banca Examinadora

Prof. Dr.

Julgamento:

Prof. Dr.

Julgamento:

Prof. Dr.

Julgamento:

Prof. Dr.

Julgamento:

Prof. Dr.

Julgamento:
Instituição:

Assinatura:

Instituição:

Assinatura:

Instituição:

Assinatura:

Instituição:

Assinatura:

Instituição:

Assinatura 
" A sabedoria é a meta da alma humana; mas a pessoa, à medida que em seus conhecimentos avança, vê o horizonte do desconhecido cada vez mais longe" Heráclito de Éfeso 


\section{AGRADECIMENTOS}

À CAPES pela concessão de bolsa nos primeiros meses de doutorado e à Fundação de Amparo à Pesquisa do Estado de São Paulo (FAPESP) pela bolsa de doutorado e de estágio no exterior (Processos \#2012/17380-8 e \#2015/10327-2) concedidos.

Ao meu orientador Prof. Dr. Augusto Flores por mais uma vez depositar confiança em meu trabalho e permitir o desenvolvimento do projeto de forma harmoniosa e tranquila e também meu co-orientador, Prof. Dr. Réjean Tremblay, por me receber em seu laboratório e me dar a oportunidade de aprender novas técnicas de laboratório.

Aos professores Dr. Stuart Jenkins, Dr. Luis Gimenez e Dra Renata Guimarães Moreira, por me auxiliarem de diferentes formas durante a execução do meu projeto e permitirem o uso de seus laboratórios sem qualquer empecilho.

À minha família Paul, Elaine e Bruno, por sempre me apoiarem nas minhas escolhas e me incentivarem a não desistir nos momentos mais difíceis. À minha segunda família, aquela que se forma ao longo da vida sem quaisquer pretensões: Fernanda Giannini, Mariana Frias de Campos, Kátia Capel e Deborah Gallo, sem o apoio de vocês, companheirismo e amizade com certeza meus caminhos teriam sido diferentes e mais difíceis! Obrigada por entrarem na minha vida e sei que não sairão mais!

Aos colegas de CEBIMar que foram fundamentais para a execução do projeto e também por tornarem a rotina mais leve: Amábile Ferreira, Bianca Tocci, Jaqueline Siquitelli, Rafael Campos Duarte, Bruno Sayão, Pedro Guerra, Karine Nascimento, Camilla Bellini, Alexandre Castagna, Andreia Barbosa, Ana Carolina Mazzuco, Ludmila Ciolfi, Mariana Biscardi, Felipe Pi, Pedro Serrao, Soledad e Sérginho. Agradeço também aos amigos que, mesmo não envolvidos diretamente no meu trabalho, foram fundamentais para não me deixar desistir e me deram força durante o doutorado: Luciana Bachega, Jaqueline Perjessy, Mauro Oróstica e Bruno Maldonado.

Finalmente, mas não menos importante, agradeço à toda equipe de técnicos, administração, biblioteca, refeitório, limpeza e manutenção do CEBIMar. Sem a presença e trabalho de vocês pouco seria possível de se realizar com tranquilidade no CEBIMar. Um agradecimento em especial para o "Seu" Elso e Joseilto, que me 
acompanharam em diversas, se não em todas as coletas e sempre me ajudaram a manter os animais vivos e bem alimentados para todos os experimentos! 


\section{RESUMO}

A variabilidade espacial e temporal do suprimento larval pode influenciar fortemente as taxas de recrutamento em populações de invertebrados marinhos do entre marés, e, assim, determinar os padrões de abundância e distribuição de adultos. No entanto, o comportamento de larvas antes do assentamento, e a sua condição fisiológica, podem também desempenhar um papel importante. Há vários fatores que influenciam a qualidade fisiológica de uma larva, sendo um deles o efeito materno, ou seja, a forma como os recursos são manipulados pelas mães para produzir sua prole, especialmente como afeta a fecundidade. Outro fator importante é o estado trófico do ambiente onde estágios iniciais se desenvolvem em estágios finais pré-competentes. No entanto, pouco se sabe sobre a relação entre esses dois processos e se a variabilidade natural das condições da costa realmente provoca uma pior qualidade no desempenho juvenil e nas taxas de recrutamento. Neste estudo nós analisamos se os processos que afetam a qualidade embrionária e larval são independentes ou interativas, e também se as condições ambientais ao longo de uma costa subtropical pode mediar tendências de qualidade de larvas à mesoescala e também determinar padrões de distribuição de invertebrados sésseis do entre marés. Usamos a craca Chthamalus bisinuatus como modelo biológico, e experimentos de laboratório e de campo foram realizados para explorar a relação de diversas variáveis ambientais nos padrões de distribuição destes cirripédios. Testamos também se as oscilações naturais na disponibilidade de alimento determinam padrões espaciais e temporais da qualidade da larva produzida e os efeitos da disponibilidade de alimento para as mães e para os seus descendentes na qualidade do estágio larval final deste organismo. Os resultados obtidos nessa tese apontam para a importância da disponibilidade de alimento na coluna d'água em determinar padrões de abundância e tamanho dos organismos adultos, bem como a relação com o grau de exposição à ação de ondas na manutenção de populações adultas. Concluímos também que mudanças sazonais na produtividade primária tem um efeito na fecundidade e qualidade da larva produzida ao longo do ano por esses cirripédios. Finalmente pudemos demonstrar que pequenas alterações na quantidade de alimento fornecida à mães e larvas de Chthamalus são suficiente para provocar 
plasticidade de alguns tratos larvais importantes para os processos e sucesso do recrutamento destes organismos.

Palavras-chave: efeitos maternos, efeitos latentes, Chthamalus bisinuatus, alimentação, qualidade larval. 


\begin{abstract}
Spatial and temporal variability of larval supply can strongly influence the recruitment rates in populations of marine intertidal invertebrates, and thus determine the abundance and distribution patterns of adults. However, the behavior of larvae prior to settlement, and its physiological condition, may also play an important role. There are several factors that influence the physiological quality of a larva, one of them being maternal effects, that is, the way resources are allocated by mothers to produce their offspring, especially the way it affects fecundity. Another important factor is the trophic state of the environment where early stages develop into competent pre-final stages. However, little is known about the relationship between these two processes and if the natural variability of coastal conditions actually causes poorer quality in young performance and recruitment rates. In this study we analyzed the processes affecting embryonic and larval quality and if they are independent or interactive, and also if the environmental conditions along a subtropical coast can mediate trends in quality larvae to mesoscale and also determine sessile intertidal invertebrates distribution patterns. We used the barnacle Chthamalus bisinuatus as a biological model, and laboratory and field experiments were conducted to explore the relationship of various environmental variables in the patterns of distribution of these barnacles. We tested also if natural fluctuations in food availability determine spatial and temporal patterns of larvae quality produced and the effects of food availability for mothers and their descendants in the quality of the final larval stage of this organisms. The results obtained in this thesis point to the importance of the food availability in the water column in determining patterns of abundance and size of adult organisms, and the relationship with the degree of exposure to wave action in the maintenance of adult populations. We also conclude that seasonal changes in primary productivity has an effect on fecundity and quality of the larvae produced throughout the year by those barnacles. Finally we were able to demonstrate that small changes in the amount of food provided to mothers and larvae Chthamalus are enough to cause plasticity of some important larval traits which impacts the processes and success of recruitment in these organisms.
\end{abstract}

Keywords: maternal effects, latent effects, Chthamalus bisinuatus, food availability, larval quality. 


\section{SUMARY}

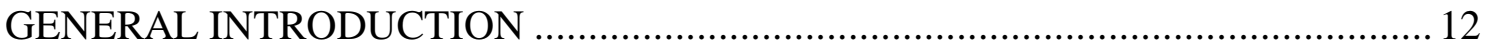

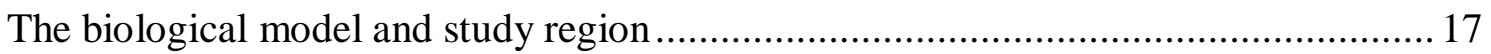

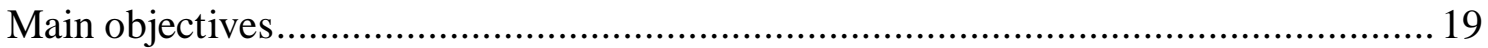

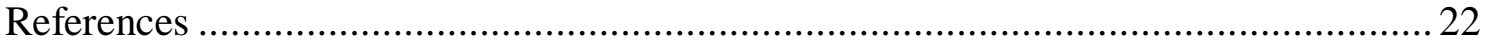

CHAPTER 01 - Biological and environmental factors linked to demography and reproductive effort of chthamalid barnacles along the southeastern coast of Brazil.....27

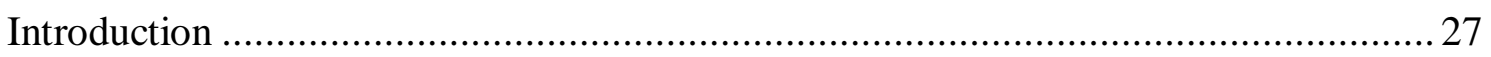

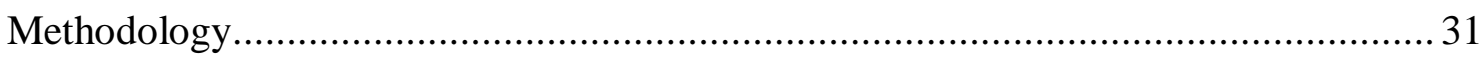

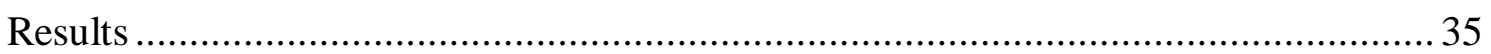

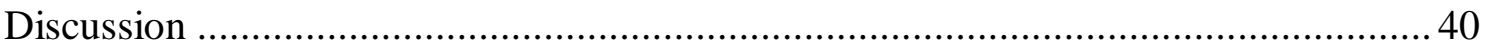

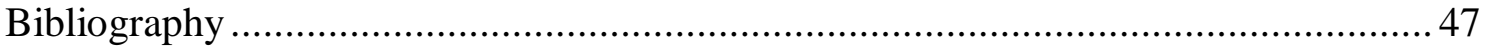

CHAPTER 02 - Seasonal patterns of larval production and quality in subtropical barnacle populations along a coastal trophic gradient ...............................................58

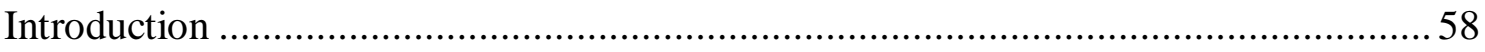

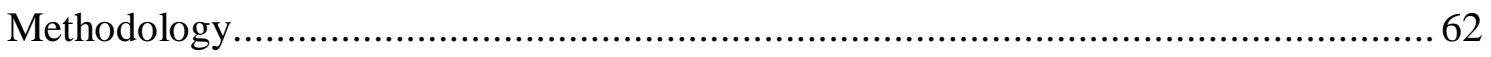

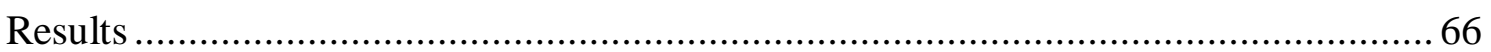

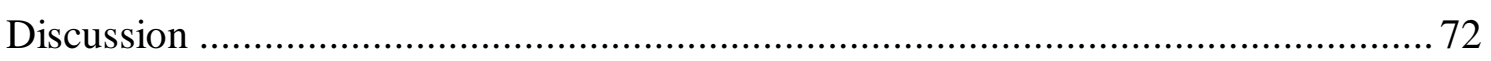

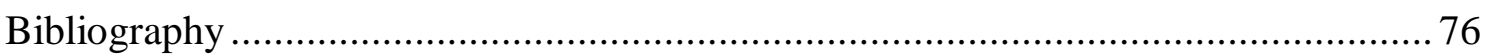

CHAPTER 03 - Maternal and pelagic resource allocation shape plastic larval responses affecting recruitment in a tropical barnacle ................................................ 89

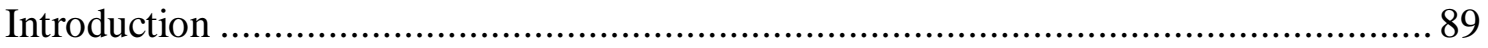

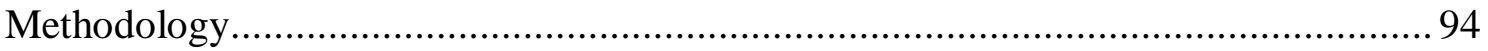

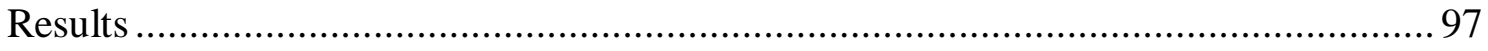

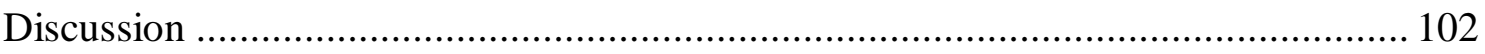

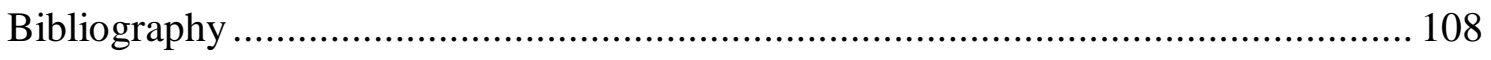

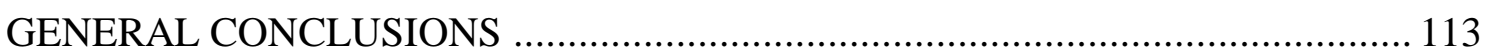

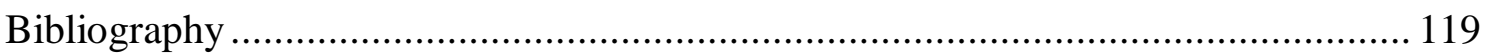




\section{GENERAL INTRODUCTION}

In marine ecology, one of the leading themes of research is how benthic populations and communities are controlled and how they respond to biological and physical factors. Majority of intertidal marine populations are generally composed by organisms presenting complex life cycles, which include one or more pelagic larval phases (Wilbur 1980; Roughgarden et al. 1988; Pechenik et al. 1998). These populations are considered as demographically open, i.e, there is an interchange among discrete populations via larval dispersal. (Roughgarden et al. 1985). In this scenario, reproduction, larval development history and recruitment, that is, the successful settlement from the plankton and survival to adulthood of new individuals into a local population becomes greatly important, as these processes are linked through an organisms life cycle and will be responsible for that population replenishment (Young 1987; Underwood and Fairweather 1989).

During the last years the idea that metamorphosis of recently settled larvae into the benthic environment is not a new beginning for that individual has grown considerably, as many authors demonstrated how different life stages of an organism are linked through different mechanisms (Diss et al. 1996; Reznick et al. 1996; Pechenik et al. 1998; Pechenik 2006). Considering the benthic adult life stage, environmental conditions experienced can alter the reproductive output of the organism (Ramirez Llodra 2002). The amount of energy available will directly influence the number and quality of the offspring produced, which in turn, could benefit or jeopardize the later recruitment of populations. The quality of recently spawned larvae depends on the amount of energy and essential nutrients that mothers can provide to offspring. This capacity, in turn, is limited by environmental resources available in adult benthic habitats, and may vary 
according to strategies of maternal resource manipulation. This latter process relies on sensorial perception skills of mothers to surrounding environmental variables signaling the trophic quality of near shore waters (an assessment of resource supply to offspring, Marshall and Uller 2007), or benthic risk cues indicating physical stress or predator presence (an assessment of the odds for future reproductive output) (Gagliano and McCormick 2009; Coslovsky and Richner 2011). This information would then underlie contrasting reproductive responses of mothers, either by preferentially allocating resources for their own and producing low quality offspring, or by transferring large portions of energetic reserves to offspring at the expense of maternal reduced performance (Bernardo 1996; Marshall and Uller 2007).

For species producing lecithotrophic larvae, i.e. propagules that do not depend on external food resources, but exclusively on endogenous energy resources, it is common for larvae to settle close to their parental population (Knowlton and Jackson 1993). In this case, the environment experienced by parental populations can be an indicator of conditions under which their progeny will develop, and so, mothers can adjust investment per propagule and maximize the combined fitness of their own and their offspring's (Qian and Chia 1991; Marshall and Uller 2007). On the other hand, when larvae enrolls a planktotrophic development, i.e., its survival depends on external food items, the maternal environment will probably not be the same experienced by larvae, because larvae with this type of development commonly remains longer in the water column and are thus subjected to greater dispersion potential (Levin 2006). In this case, any cues perceived by maternal populations may not be interpreted as the conditions their progeny will experience. Under this scenario, mothers can distribute 
resources to their offspring unevenly, producing larvae of variable quality even within the same batch, which would ensure survival of at least a small fraction of their larvae (a bet-hedging strategy; Marshall et al. 2008).

Once in the water column, larvae are submitted to different physical conditions and biological interactions which can modify its survival until settlement. The so called pre-settlement processes (Pineda et al. 2009) include larval yield, larval traits and behavior, such as the amount of larvae available for settlement in the near shore habitat (larval supply), their energetic composition to develop competence (larval quality), to explore benthic habitat and to metamorphose successfully. While in the plankton, larval pools may be substantially reduced by predation (Bailey and Houde 1989; Leggett and Deblois 1994) and by dietary deficiency, affecting larval supply. Also, they may be lost by dispersal, as near shore currents (Cowen and Sponaugle 2009) and other oceanographic processes (Largier 2003; Gawarkiewicz et al. 2007) can drift larvae away from appropriate benthic habitat adult populations (Levin 2006). Temporal and spatial variations on larval supply can strongly influence recruitment patterns and thus determine adult abundance and distribution (Hughes et al. 2000; Jonsson et al. 2004). Not only that, studies have demonstrated that selective larval behavior upon contact with settlement surfaces may also determine recruitment patterns (Jenkins 2005). Field and laboratory evidence suggests that those factors influencing larval supply might also influence the physiological quality of larvae, consequently affecting the individual performance during its juvenile and adult phases (Jarrett and Pechenik 1997; Miron et al. 1999).

Different factors can influence larval quality, like the length of the pelagic phase (Pechenik et al. 1998), exposure to pollutants (Pechenik et al. 2001), food 
availability and quality (Toupoint et al. 2012; Pechenik and Tyrell 2015) and temperature (Fukazawa et al. 2005). From this it becomes clear that spatial and temporal variability on oceanographic conditions might directly influence on larval quality, or indirectly, considering that distinct adult populations can show phenotypic variability in response to environmental conditions which they are submitted to and thus modify the quality of the offspring produced (Bertness et al. 1991; Jenkins et al. 2001; Brind'Amour et al. 2002).

Determinants of larval quality, either over embryogenesis and dictated by maternal allocation, or over larval development and mainly controlled by pelagic food resources, will affect not only larval yield to benthic populations, but also the odds for per capita settlement success and later benthic performance (Bertram and Strathmann 1998; Emlet and Sadro 2006; Ezeakacha 2015). For instance, increased temperature can accelerate larval development (Anil and Kurian 1996; Anil et al. 2001), which reduces the time spent in the plankton and, in turn, decreases predation and dispersion risk (O'Connor et al. 2007). At the same time, elevated temperatures enhance the metabolism of larvae (Brockington and Clarke 2001), making the encounter of adequate food supply a crucial factor for their survival. Also, food limitation during the larval planktonic stage is known to strongly and negatively affect the juvenile development of some benthic invertebrates, as demonstrated by Emlet and Sadro (2006).

After developing in the plankton and gathering energy, larvae become competent and are able to settle, returning to the benthic habitat. At this life stage, organisms are submitted to post-settlement processes, which can lead to early juvenile mortality. In fact, early juvenile mortality of benthic organisms is extremely high and can produce critical implications on population parameters 
(Gosselin and Qian 1997). Sources of early juvenile mortality can be either biotic, like predation (Fernandez et al. 1993), competition for space (Denley and Underwood 1979) or food (Gosselin and Chia 1994) and the amount of energetic reserves left after metamorphosis, or abiotic, being desiccation and thermal stress (Jenewein and Gosselin 2013) the most studied sources of juvenile mortality on a variety of intertidal organisms. It become clear that, due to high mortality rates of early juveniles, settlement and recruitment are not necessarily linearly related, as observed by Pineda and colleagues (2006). The former authors have shown a favorable recruitment window for benthic intertidal organisms which, if missed by larvae, could result in low survival to adult phase, altering the population dynamics. Thus, the recruitment window, which can be the result of combined effects of both biotic and abiotic factors, impacts the larval and early juvenile phases of organisms, stressing the importance of identifying key processes that occur before and after the larvae settles and its consequences to population dynamics.

Due to the aggregated distribution of phytoplankton and the dynamics of near shore circulation, both larvae and maternal populations of filter feeding invertebrates are subjected to great fluctuations of both the quality and the quantity of pelagic food resources. Whatever is the pelagic environment, parents need to build up energy reserves and allocate them for both their own metabolic needs and reproduction. In turn, larvae need to store energetic resources and essential elements ensuring their development and metamorphosis to the juvenile benthic stage. Through maternal effects, the conditions experienced by maternal populations will have an effect on the offspring produced (Freuchet et al. 2015) and can be carried-over until later ontogenetic stages (Solemdal 1997; Vigliola and 
Meekan 2002; Raventos and Macpherson 2005; Gagliano and McCormick 2007; Plaistow and Benton 2009).

Understanding the importance of maternal population experience and the natural dynamics of the environment where intertidal animals inhabit has to their reproductive and larval traits is crucial for predicting and better explaining how intertidal populations will respond to stochastic environmental fluctuations. Exploring the possible relation between different life cycle phases becomes greatly important for better understanding how these populations maintain itself through time and space.

In this study we proposed three different approaches (chapters) to elucidate some of these questions. We used the chthamalid barnacle Chthamalus bisinuatus (Pilsbry 1916), a very common species along the Brazilian coastline, as a model species to better understand (i) how environmental factors can influence demographic and reproductive parameters in natural populations of this barnacle, (ii) how food availability affect both the quantity and quality of barnacle larval production and (iii) how maternal allocation and pelagic food supply affect important key components of barnacle early recruitment.

\section{The biological model and study region}

The barnacle Chthamalus bisinuatus is present in dense aggregations on the upper intertidal zone of rocky shores along the Brazilian coast. These filter feeding animals reproduce through crossed fertilization - although some cases of selffertilization have been reported for this genus (Barnes and Crisp 1956; Anderson 1994) - and the fertilized eggs are carried in the mantle cavity until the first larval stage, the nauplii, is fully developed. Once in the plankton, nauplii feed and moult 
into 6 different stages until they metamorphose into the late larval phase, the cyprid, a non-feeding stage. Thus, the energy accumulated until the cyprid phase will directly influence the exploration capacity to find an adequate settlement surface, and to metamorphose successfully into the first juvenile stage (for exemple Thiyagarajan et al. 2002b; Thiyagarajan et al. 2002a; Jarrett 2003; Tremblay et al. 2007) . Chthamalus bisinuatus presents a spawning behavior that likely favors larval retention near the coast (Bueno et al. 2010; Kasten and Flores 2013), and therefore the maternal environment during immersion may accurately cue the trophic pelagic status that larvae will face when released. For this matter, this species is a good biological model for scientific work aiming a better understating of ways in which local oceanographic conditions modulate reproductive strategies, including reproductive effort in terms of overall output and larval quality. As a species distributed over a generally nutrient-poor coastline, trophic inputs through embryogenesis and early larval stages are likely to endure through benthic stages as carry-over effects still not fully understood.

Because these cirripedes are widely distributed along the South American coast, being present from the Uruguayan coast until the Northeast of Brazil (Dando and Southward 1980; Young 1993), these invertebrates face different local oceanographic regimes within a general oligotrophic regime. However, urban development had significantly altered this situation. In the Southern coast of São Paulo State, the Baixada Santista is a large urban cluster encompassing the cities of Praia Grande, São Vicente, Santos and Guarujá with over 1.5 million inhabitants, and the adjacent estuarine system and coastal ocean are heavily polluted and nutrient-enriched by large loads industrial sewage from the pole of Cubatão and domestic urban discharge (Braga et al. 2000; Aguiar and Braga 2007). On the 
contrary, the north coast of the State, including the counties of São Sebastião, Ilhabela, Caraguatatuba and Ubatuba is a much less impacted area, with much lower primary production and dissolved organic matter contents (Gaeta et al. 1999; Gianesella et al. 1999). Natural enrichment of the water column at less disturbed coastlines depend on very restricted upwelling mostly during summer (Guenther et al. 2008) or the passage of cold fronts, chiefly during winter (Ciotti et al. 2010), owing to remote meteorological forcing. At present, it is virtually unknown how corridors of nutrient-enriched water and episodic vertical mixing contribute to population stability through bottom-up effects on adult reproductive output and larval connectivity.

The existing studies regarding chthamalid barnacles along the Brazilian coast have focused on larval recruitment (Dube et al. 1981; Tanaka and Duarte 1998; Nery et al. 2008; Skinner and Coutinho 2010; de Guimaraens et al. 2011; Mazzuco et al. 2015; Barbosa et al. 2016), spawning rhythms (Bueno et al. 2010; Kasten and Flores 2013), zonation patterns (Masi and Zalmon 2008) a check list of shallow water species (Farrapeira 2010), a note on the first observation of a new species (Oliveira 1940) and maternal effects on larval quality (Freuchet et al. 2015). So far, no attempts have been undertaken to examine effects of environmental drivers that may determine the distribution and reproductive potential of natural populations. The present study is a first step to fulfill this gap.

\section{Main objectives}

In this work, we aimed to better understand how different environmental factors act on different phases of the life cycle of Chthamalus bisinuatus and how their effects can be translated into larval quality, recruitment patterns and other 
benthic population parameters. First (Chapter 1) we used satellite images and in situ quantification of several parameters to evaluate relationships between key environmental variables and population features indicating reproductive potential along nearly $600 \mathrm{~km}$ of coastline, including the states of São Paulo and Rio de Janeiro. This part of the thesis is mostly a descriptive study, with no hypothesis testing. Results should be regarded as a first glance of mechanisms that might determine the distribution and maintenance of chthamalid barnacle populations along a subtropical coast. Relationships were tested through standard correlation and regression techniques and attempted the identification of environmental variables associated to $C$. bisinuatus population traits. Our findings supports the critical role of pelagic food supply to sustain dense population of this filter feeding invertebrate in the intertidal zone along the subtropical coast surveyed.

Second (Chapter 2), we addressed the possible influence of natural variation of food availability for parental populations of $C$. bisinuatus over some reproductive aspects and consequences in larval traits. With a large scale field sampling covering different chthamalid populations under different trophic regimes we expected to understand how the environment where adults inhabit might affect their fecundity and nauplii quality along the coastline of São Paulo state. The hypothesis tested was that seasonal differences in natural food availability for parental populations could interfere on larval quality through maternal effects and that, depending on the amount of food available, mothers could adopt different reproductive strategies. Using satellite images we could detect both seasonal and spatial differences in chlorophyll- $a$ and particulate organic carbon content in the water column along the sampled coastline. Also, we observed a seasonal shift between fecundity and larval quality, being more larvae 
produced during summer months, but with lower quality then the larvae produced during winter months, which in turn were produced in a lower number. Although it is known that this chthamalid barnacle reproduces year round, this was the first observation of higher quality nauplii being produced out of the main reproductive season, which could lead to a discrete recruitment pulse offseason.

Finally (Chapter 3), we focused on sources of variation in cyprid quality, as this final stage does not feed and depends on the amount of energy gathered during oogenesis and larval development to reach competence, search for an adequate substratum and settle. As shown previously, cyprid quality can be influenced by both the maternal and pelagic environment, so we manipulated in a factorial design the food supply to adults and larvae of the barnacle Chthamalus bisinuatus and measured (i) naupliar development rate, and both (ii) the total yield and (iii) the quality of late stage larvae. We aimed to test how much of the cyprids final quality is dictated by maternal effects and by larval experiences in the plankton. The hypothesis tested was that cyprid final quality is influenced by either maternal or pelagic effects a combined effect of both. Food supply and temperature were the factors manipulated to create different environmental conditions for both mothers and larvae. Depending on the kind of interaction displayed between this two effects, energy allocation strategies could vary drastically, so this study provided better understanding of the reproductive ecology of these animals. Our results showed substantial plasticity on maternal allocation and larval development. Adults fed with a restrained diet released two times more larvae than adults given a high food supply, compatible to an anticipatory maternal effect (AME). In spite of equal mortality rates up to the cyprid stage, such surplus larval production rendered sub standard development 
rate under low pelagic food supply. Regardless of pelagic allocation, this AME strategy also rendered lower cyprid size. When fed a non-restrained diet, mothers producing larger cyprids may increase survival of recruits; a strategy compatible to a bet-hedging maternal effect.

\section{References}

Aguiar V, Braga E (2007) Seasonal and tidal variability of phosphorus along a salinity gradient in the heavily polluted estuarine system of Santos/São Vicente - São Paulo, Brazil. Mar Pollut Bull 54:464-471. doi: 10.1016/j.marpolbul.2006.11.001

Anderson D (1994) Barnacles - Structure, function, development and evolution.

Anil A, Desai D, Khandeparker L (2001) Larval development and metamorphosis in Balanus amphitrite Darwin (Cirripedia; Thoracica): significance of food concentration, temperature and nucleic acids. J Exp Mar Bio Ecol 263:125-141. doi: 10.1016/S0022-0981(01)00280-5

Anil A, Kurian J (1996) Influence of food concentration, temperature and salinity on the larval development of Balanus amphitrite. Mar Biol 127:115-124. doi: 10.1007/BF00993651

Bailey K, Houde E (1989) Predation on Eggs and Larvae of Marine Fishes and the Recruitment Problem. Adv Mar Biol 25:1-83. doi: 10.1016/S00652881(08)60187-X

Barbosa A, Gomes C, Pereira G, et al (2016) Local biological drivers, not remote forcing, predict settlement rate to a subtropical barnacle population. Mar Ecol Prog Ser. doi: $10.3354 /$ meps 11589

Barnes H, Crisp D (1956) Evidence of self-fertilization in certain species of barnacles. J Mar Biol Assoc UK 35:631-639.

Bernardo J (1996) Maternal effects in animal ecology. Am Zool 36:83-105.

Bertness M, Gaines S, Bermudez D, Sanford E (1991) Extreme spatial variation in the growth and reproductive output of the acorn barnacle Semibalanus balanoides. Mar Ecol Prog Ser 75:91-100. doi: 10.3354/meps075091

Bertram D, Strathmann R (1998) Effects of maternal and larval nutrition on growth and form of planktotrophic larvae. Ecology 79:315-327.

Braga E, Bonetti C, Burone L, Bonetti Filho J (2000) Eutrophication and Bacterial Pollution Caused by Industrial and Domestic Wastes at the Baixada Santista Estuarine System - Brazil. Mar Pollut Bull 40:165-173. doi: 10.1016/S0025326X(99)00199-X

Brind'Amour A, Bourget E, Tremblay R (2002) Fecundity, growth rate and survivorship at the interface between two contiguous genetically distinct groups of Semibalanus balanoides. Mar Ecol Prog Ser 229:173-184. doi: 10.3354/meps 229173

Brockington S, Clarke a (2001) The relative influence of temperature and food on the metabolism of a marine invertebrate. J Exp Mar Bio Ecol 258:87-99. doi: 10.1016/S0022-0981(00)00347-6

Bueno M, Moser G, Tocci B, Flores A (2010) Retention-favorable timing of propagule release in barnacles and periwinkles. Mar Ecol Prog Ser 414:155-165. doi: 
10.3354/meps08715

Ciotti Á, Garcia C, Jorge D (2010) Temporal and meridional variability of Satelliteestimates of surface chlorophyll concentration over the Brazilian continental shelf. Pan-American J ... 5:236-253.

Coslovsky M, Richner H (2011) Predation risk affects offspring growth via maternal effects. Funct Ecol 25:878-888. doi: 10.1111/j.1365-2435.2011.01834.x

Cowen R, Sponaugle S (2009) Larval Dispersal and Marine Population Connectivity. Ann Rev Mar Sci 1:443-466. doi: 10.1146/annurev.marine.010908.163757

Dando P, Southward A (1980) A new species of Chthamalus (Crustacea: Cirripedia) characterized by enzyme electrophoresis and shell morphology: with a revision of other species of Chthamalus from the western shores of the atlantic ocean. J Mar Biol Assoc United Kingdom 60:787. doi: 10.1017/S0025315400040455

de Guimaraens M, de Araújo Luz B, Carneiro J, da Silva J (2011) Modeling the succession of barnacles and mussels on a sandstone reef in Pernambuco State, Brazil. Hydrobiologia 658:365-372. doi: 10.1007/s10750-010-0506-2

Denley E, Underwood A (1979) Experiments on factors influencing settlement, survival, and growth of two species of barnacles in New South Wales. J Exp Mar Bio Ecol 36:269-293.

Diss A, Kunkel J, Montgomery M, Leonard D (1996) Effects of maternal nutrition and egg provisioning on parameters of larval hatch, survival and dispersal in the gypsy moth, Lymantria dispar L. Oecologia 106:470-477. doi: 10.1007/BF00329704

Dube V, Nunes T, Almeida V (1981) Registros e considerações sobre inibição da colonização de ostras e cracas no estuário do Rio Jacuruna e Canal de Itaparica (Bahia). Memoriais do Inst Oswaldo Cruz 76:121-129.

Emlet R, Sadro S (2006) Linking stages of life history: How larval quality translates into juvenile performance for an intertidal barnacle (Balanus glandula). Integr Comp Biol 46:334-346. doi: 10.1093/icb/icj023

Ezeakacha N (2015) Environmental impacts and carry-over effects in complex life cycles: the role of different life histories stages.

Farrapeira C (2010) Shallow water Cirripedia of the northeastern coast of Brazil: The impact of life history and invasion on biogeography. J Exp Mar Bio Ecol 392:210 219. doi: 10.1016/j.jembe.2010.04.021

Fernandez M, Iribarne O, Armstrong D (1993) Habitat Selection By Young-of-the-Year Dungeness Crab Cancer-Magister and Predation Risk in Intertidal Habitats. Mar Ecol Prog Ser 92:171-177. doi: 10.3354/meps092171

Freuchet F, Tremblay R, Flores A (2015) Interacting environmental stressors modulate reproductive output and larval performance in a tropical intertidal barnacle. Mar Ecol Prog Ser 532:161-175. doi: 10.3354/meps11377

Fukazawa H, Takami H, Kawamura T, Watanabe Y (2005) The effect of egg quality on larval period and postlarval survival of an abalone Haliotis discus hannai. J Shellfish Res 24:1141-1147.

Gaeta S, Ribeiro S, Metzler P, et al (1999) Environmental forcing on phytoplankton biomass and primary productivity of the coastal ecosystem in Ubatuba region, southern Brazil. Rev Bras Oceanogr 47:11-27.

Gagliano M, McCormick M (2009) Hormonally mediated maternal effects shape offspring survival potential in stressful environments. Oecologia 160:657-665. doi: 10.1007/s00442-009-1335-8

Gagliano M, McCormick M (2007) Maternal condition influences phenotypic selection on offspring. J Anim Ecol 76:174-182. doi: 10.1111/j.1365-2656.2006.01187.x

Gawarkiewicz G, Monismith S, Largier J (2007) Observing Larval Transport Processes 
Affecting Population Connectivity: Progress and Challenges. Oceanography 20:40 - 53. doi: 10.5670/oceanog.2007.28

Gianesella S, Kutner M, Saldanha-Corrêa F, Pompeu M (1999) Assessment of plankton community and environmental conditions in São Sebastião Channel prior to the construction of a produced water outfall. Rev Bras Oceanogr 47:29-46.

Gosselin L, Chia F (1994) Feeding habits of newly hatched juveniles of an intertidal predatory gastropod, Nucella emarginata (Deshayes). J Exp Mar Bio Ecol 176:113. doi: 10.1016/0022-0981(94)90193-7

Gosselin L, Qian P (1997) Juvenile mortality in benthic marine invertebrates. Mar Ecol Prog Ser 146:265-282. doi: 10.3354/meps146265

Guenther M, Gonzalez-Rodriguez E, Carvalho W, et al (2008) Plankton trophic structure and particulate organic carbon production during a coastal downwellingupwelling cycle. Mar Ecol Prog Ser 363:109-119. doi: 10.3354/meps07458

Hughes T, Baird A, Dinsdale E, et al (2000) Supply-Side Ecology Works Both Ways: The Link between Benthic Adults, Fecundity, and Larval Recruits. Ecology 81:2241-2249. doi: 10.2307/177111

Jarrett J (2003) Seasonal Variation in Larval Condition and Postsettlement Performance of the Barnacle Semibalanus Balanoides. Ecology 84:384-390. doi: 10.1890/00129658(2003)084[0384:SVILCA]2.0.CO;2

Jarrett J, Pechenik J (1997) Temporal Variation in Cyprid Quality and Juvenile Growth Capacity for an Intertidal Barnacle. Ecology 78:1262-1265. doi: 10.1890/00129658(1997)078[1262:TVICQA]2.0.CO;2

Jenewein B, Gosselin L (2013) Ontogenetic shift in stress tolerance thresholds of Mytilus trossulus: Effects of desiccation and heat on juvenile mortality. Mar Ecol Prog Ser 481:147-159. doi: 10.3354/meps10221

Jenkins S, Aberg P, Cervin G, et al (2001) Population dynamics of the intertidal barnacle Semibalanus balanoides at three European locations: Spatial scales of variability. Mar Ecol Prog Ser 217:207-217. doi: 10.3354/meps217207

Jenkins SR (2005) Larval habitat selection, not larval supply, determines settlement patterns and adult distribution in two chthamalid barnacles. J Anim Ecol 74:893904. doi: 10.1111/j.1365-2656.2005.00985.x

Jonsson P, Berntsson K, Larsson A (2004) Linking Larval Supply To Recruitment: Flow-Mediated Control of Initial Adhesion of Barnacle Larvae. Ecology 85:28502859. doi: 10.1890/03-0565

Kasten P, Flores A (2013) Disruption of endogenous tidal rhythms of larval release linked to food supply and heat stress in an intertidal barnacle. Mar Ecol Prog Ser 472:185-198. doi: 10.3354/meps10005

Knowlton N, Jackson J (1993) Inbreeding and outbreeding in marine invertebrates. The natural history of inbreeding and outbreeding. pp 200-249

Largier J (2003) Considerations in Estimating Larval Dispersal Distances from Oceanographic Data. Ecol Appl 13:71-89.

Leggett W, Deblois E (1994) Recruitment in marine fishes: Is it regulated by starvation and predation in the egg and larval stages? Netherlands J Sea Res 32:119-134. doi: 10.1016/0077-7579(94)90036-1

Levin L a (2006) Recent progress in understanding larval dispersal: new directions and digressions. Integr Comp Biol 46:282-97. doi: 10.1093/icb/icj024

Marshall D, Bonduriansky R, Bussière L (2008) Offspring size variation within broods as a bet-hedging strategy in unpredictable environments. Ecology 89:2506-2517.

Marshall J, Uller T (2007) When is a maternal effect adaptive? Oikos 116:1957-1963. doi: 10.1111/j.2007.0030-1299.16203.x 
Masi B, Zalmon I (2008) Zonação de comunidade bêntica do entremarés em molhes sob diferente hidrodinamismo na costa norte do estado do Rio de Janeiro, Brasil. Rev Bras Zool 25:662-673. doi: 10.1590/S0101-81752008000400011

Mazzuco A, Christofoletti R, Pineda J, et al (2015) Temporal variation in intertidal community recruitment and its relationships to physical forcings, chlorophyll-a concentration and sea surface temperature. Mar Biol. doi: 10.1007/s00227-0152689-6

McCormick M, Gagliano M (2008) Carry-over effects: the importance of a good start. The 11th International Coral Reef Symposium.

Miron G, Boudreau B, Bourget E (1999) Intertidal barnacle distribution:a case study using multiple working hypotheses. Mar Ecol Prog Ser 189:205-219. doi: 10.3354/meps 189205

Nery P, Leitão S, Fernandes M, et al (2008) Recrutamento e sucessão ecológica da macrofauna incrustante em substratos no porto do Recife-PE, Brasil. Rev Bras Eng Pesca 3:51-61.

O’Connor M, Bruno J, Gaines S, et al (2007) Temperature control of larval dispersal and the implications for marine ecology, evolution, and conservation. Proc Natl Acad Sci U S A 104:1266-1271. doi: 10.1073/pnas.0603422104

Oliveira L (1940) Sobre uma nova espécie de crustaceo Chthamalus rhizophorae. Mem Inst Oswaldo Cruz 35:379-381.

Pechenik J (2006) Larval experience and latent effects--metamorphosis is not a new beginning. Integr Comp Biol 46:323-333. doi: 10.1093/icb/icj028

Pechenik J, Gleason T, Daniels D, Champlin D (2001) Influence of larval exposure to salinity and cadmium stress on juvenile performance of two marine invertebrates (Capitella sp. I and Crepidula fornicata). J Exp Mar Bio Ecol 264:101-114. doi: 10.1016/S0022-0981(01)00313-6

Pechenik J, Tyrell A (2015) Larval diet alters larval growth rates and post-metamorphic performance in the marine gastropod Crepidula fornicata. Mar Biol. doi: 10.1007/s00227-015-2696-7

Pechenik J, Wendt D, Jarrett J (1998) Metamorphosis Is Not a New Beginning Larval experience influences juvenile performance. Bioscience 48:901-910.

Pilsbry H (1916) The sessile barnacles (cirripedia) contained in the collections of the U.S. National museum; including a monograph oh the american species.

Pineda J, Reyns N, Starczak V (2009) Complexity and simplification in understanding recruitment in benthic populations. Popul Ecol 51:17-32. doi: 10.1007/s10144008-0118-0

Pineda J, Starczak V, Stueckle T (2006) Timing of successful settlement: Demonstration of a recruitment window in the barnacle Semibalanus balanoides. Mar Ecol Prog Ser 320:233-237. doi: 10.3354/meps320233

Plaistow S, Benton T (2009) The influence of context-dependent maternal effects on population dynamics: an experimental test. Philos Trans R Soc Lond B Biol Sci 364:1049-1058. doi: 10.1098/rstb.2008.0251

Qian P, Chia F (1991) Fecundity and egg size are mediated by food quality in the polychaete worm Capitella sp. J Exp Mar Bio Ecol 148:11-25.

Ramirez Llodra E (2002) Fecundity and life-history strategies in marine invertebrates. Raventos N, Macpherson E (2005) Effect of pelagic larval growth and size-at-hatching on post-settlement survivorship in two temperate labrid fish of the genus Symphodus. Mar Ecol Prog Ser 285:205-211. doi: 10.3354/meps285205

Reznick D, Callahan H, Llauredo R (1996) Maternal Effects on Offspring Quality in Poeciliid Fishes. Am Zool 36:147-156. 
Roughgarden J, Gaines S, Possingham H (1988) Recruitment dynamics in complex life cycles. Science (80- ) 241:1460 - 1466.

Roughgarden J, Iwasa Y, Blaxter C (1985) Demographic theory for an open population with space-limited recruitment. Ecology 66:54-67. doi: 10.2307/1941306

Skinner L, Coutinho R (2010) Preliminary results on settlement of the barnacles Tetraclita stalactifera and Chthamalus bisinuatus on a Brazilian tropical rocky shore under upwelling conditions. Invertebr Reprod Dev 41:151-156. doi: 10.1080/07924259.2002.9652746

Solemdal P (1997) Maternal effects - A link between the past and the future. J Sea Res 37:213-227. doi: 10.1016/S1385-1101(97)00029-4

Tanaka M, Duarte L (1998) Recruitment variation of the barnacle Chthamalus bisinuatus Pilsbry 1916 in an exposed rocky shore in southeast Brazil. Bull Mar Sci 62:285-292.

Thiyagarajan V, Harder T, Qian P (2002b) Effect of the physiological condition of cyprids and laboratory-mimicked seasonal conditions on the metamorphic successes of Balanus amphitrite Darwin (Cirripedia; Thoracica). J Exp Mar Bio Ecol 274:65-74. doi: 10.1016/S0022-0981(02)00182-X

Thiyagarajan V, Harder T, Qian P (2002a) Relationship between cyprid energy reserves and metamorphosis in the barnacle Balanus amphitrite Darwin (Cirripedia; Thoracica). J Exp Mar Bio Ecol 280:79-93. doi: 10.1016/S0022-0981(02)00415-X

Toupoint N, Gilmore-Solomon L, Bourque F, et al (2012) Match/mismatch between the Mytilus edulis larval supply and seston quality: effect on recruitment. Ecology 93:1922-1934. doi: 10.1890/11-1292.1

Tremblay R, Olivier F, Bourget E, Rittschof D (2007) Physiological condition of Balanus amphitrite cyprid larvae determines habitat selection success. Mar Ecol Prog Ser 340:1-8. doi: 10.3354/meps340001

Underwood A, Fairweather P (1989) Supply-side ecology and benthic marine assemblages. Trends Ecol Evol 4:16-20. doi: 10.1016/0169-5347(89)90008-6

Vigliola L, Meekan M (2002) Size at hatching and planktonic growth determine postsettlement survivorship of a coral reef fish. Oecologia 131:89-93. doi: 10.1007/s00442-001-0866-4

Wilbur H (1980) Complex Life Cycles. Annu Rev Ecol Syst 11:67-93. doi: 10.1146/annurev.es.11.110180.000435

Young C (1987) Novelty of "Supply-Side Ecology'. Science (80- ) 235:415-416.

Young P (1993) The Verrucomorpha Chthamaloidea from the Brazilian coast (Crustacea: Cirripedia). Rev Bras Biol 53:255-267. 


\section{CHAPTER 01 - Biological and environmental factors linked to demography and reproductive effort of chthamalid barnacles along the southeastern coast of Brazil.}

\section{Introduction}

Chthamalid barnacles are sessile marine crustaceans spread worldwide, with more than 20 species recognized from temperate to subtropical regions (Dando and Southward 1980; Southward and Newman 2003; Pitombo and Burton 2007). These animals inhabit mainly the higher intertidal zone of rocky shores, and are thus subjected to stressful conditions of desiccation, temperature, wave action and food supply, owing to the reduced immersion time they experience (Lewis 1964; Newell 1970; Anderson 1994; Helmuth and Hofmann 2001). Barnacles undergo a complex life cycle, depending on several factors, like favorable larval transport and suitable pelagic food supply for benthic population replenishment (Pineda et al. 2009). Biological factors play important roles on the survival and reproductive cycles of these animals. Interactions like predation, competition for space and food and facilitation are known for altering the distribution and maintenance of chthamalid barnacles. For these reasons, understanding which factors might regulate the distribution and reproduction output of chthamalid barnacles may help to better understand the dynamics of these populations.

Different factors act on the distribution of chthamalid barnacles at different ontogenetic phases. Processes occurring before settlement such as cyprid supply, substrate selection and attachment behavior are key factors determining settlement and early recruitment rates (Minchinton and Scheibling 1991; Jenkins 2005; López and Coutinho 2008; Pineda et al. 2010). After metamorphosing to the 
juvenile phase, survival and growth until a reproductive size can also largely impact the maintenance of these populations (Connell 1985; Raimondi 1990; Gosselin and Qian 1996; Tanaka and Duarte 1998). Important post-settlement processes affecting population density and size structure may include, competition and facilitation (Foster 1987; O'Riordan et al. 2010).

When competing for space with other barnacles, chthamalids seem to be more adapted to desiccation, thermal stress and food limitation, allowing colonization of the upper shore, differently from balanid barnacles which cannot stand such harsh conditions (Connell 1961a; Foster 1971a; Foster 1971b). Also, foraging strategy apparently benefits smaller chthamalid barnacles provides, since predators on rocky shores tend to pray mainly on balanids rather than chthamalid barnacles (Connell 1961b; Gosselin and Chia 1996). Predation on balanid barnacles can also produce an indirect positive interaction for chthamalids, as the removal of these other barnacles decrease competition (Dungan 1986; BenedettiCecchi 2000; Arrontes et al. 2004; Harley 2006; Zabin and Altieri 2007).

Environmental gradients along shores can also modify the observed distribution patterns of these barnacles at larger scales, by either acting on their survival or on their reproduction. Wave action is one of such factors, and its effects may operate in different ways. First, as barnacles are sessile filter feeders, their amount of food intake will be closely related to the degree of wave action. Increased wave-action might imply on higher delivery of food particles which can result in a positive effect by enhancing growth rate and survival in adult individuals (Southward and Crisp 1956; Lewis 1964; Wethey 1983; Bertness et al. 1991). Second, wave action mitigates thermal stress and reduces desiccation risk by wetting individuals through both water splash and spray (Helmuth et al. 2006). 
Third, enhanced wave action also promotes higher concentrations of near shore larval supply, which can enhance the settlement rate on wave exposed sites (Minchinton and Scheibling 1991). Under high settlement conditions, bare space is rapidly occupied, leaving little space for growth. In such circumstances, barnacle tend to form hummocks, turning that habitat unstable, as this formations are more vulnerable to dislodgment due to wave action (Bertness et al. 1998).

Food supply also plays an important role for the maintenance of barnacle populations. Dense aggregations were observed when food availability was high (Hines 1978; Menge et al. 1997), and larval release rate can be correlated with food supply (Kasten and Flores 2013), suggesting that both growth rate and reproductive output of chthamalid barnacles may frequently be food-limited. Temperature can also affect the distribution and density of these barnacles, both at a large geographical, setting species range limits (Orton 1920; Hutchins 1947), or very locally, causing mass mortality during heat wave events (Garrabou et al. 2009). Also, temperature can influence directly on the physiological constraints for barnacles reproduction, altering the number and quality of larvae spawned by chthamalids (Freuchet et al. 2015).

O'Riordan and colleagues (2010) reviewed the main factors influencing the distribution of chthamalid barnacles, but most of the available information at that time was related to temperate species from Europe and North America. The authors presented data showing that different processes act on chthamalid distribution patterns at different spatial scales. At a micro scale, local factors are more important for chthamalid distribution and biological interactions between facilitation, competition, predation, larval supply and abiotic variables are the main contributors of such distribution. At a regional scale climatic and abiotic factors 
remain as the main influence on chthamalid distribution and, for global scales, the distribution is controlled by tectonic processes, ocean level alteration, oceanographic and climatic processes that happened at a geological time scale (O'Riordan et al. 2010). Information on tropical or subtropical species is relatively scarce and at your knowledge limited to Guiler 1955; Southward and Newman 2003; Pitt et al. 2010; Shahdadi and Sari 2010). Sutherland (1990) pointed out that most barnacle populations from temperate regions are controlled by densitydependent events, while barnacle populations from tropical region would be controlled by settlement variations, with no relation to density-dependent processes. These trends arise mostly from factors acting at a small scale, and so far no general trend has been proposed to better understand large scale distribution and maintenance of barnacles at tropical regions. In this study we show for the first time at large scale which environmental factors are linked to demographic and reproductive traits of Chthamalus populations along a subtropical coast in Southeastern Brazil.

Through satellite images and in situ measurements, we used multiple regression techniques to test relationships among key environmental variables and parameters describing the demography and reproductive potential of Chthamalus bisinuatus populations in a wide transition zone, from subtropical to tropical characteristics (e.g. (Floeter and Soares-Gomes 1999; Benkendorfer and Soares-Gomes 2009) of the Southwestern Atlantic. This more exploratory approach will allow context-based hypothesis testing in future experimental studies. 


\section{Methodology}

Brazilian coast are characterized by two Chthamalid species: Chthamalus bisinuatus (Pilsbry 1916) and Chthamalus proteus (Dando and Southward 1980) being the first a South-Atlantic endemic species, present from the Uruguayan coast until Piauí State in Brazil and the second is an introduced species, present from Florianópolis State in Brazil until the Florida State in the United States (Dando and Southward 1980; Young 1993). Field sampling from Búzios, Rio de Janeiro State

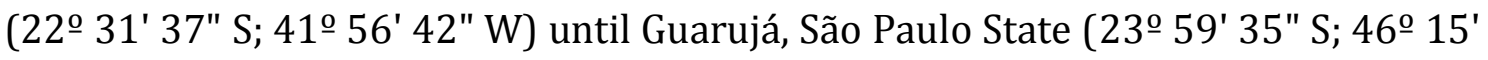
$23 "$ W) was performed during period of the main reproductive 2014 season of chthamalid barnacles in the region (Figure 1). In total, 36 rocky shores along more than $600 \mathrm{~km}$ of coast line were sampled for chthamalid cover, percentage of individuals with developed eggs and individual size. The sampling of all sites were realized from September to December 2014 during the main reproductive season of this barnacles. 


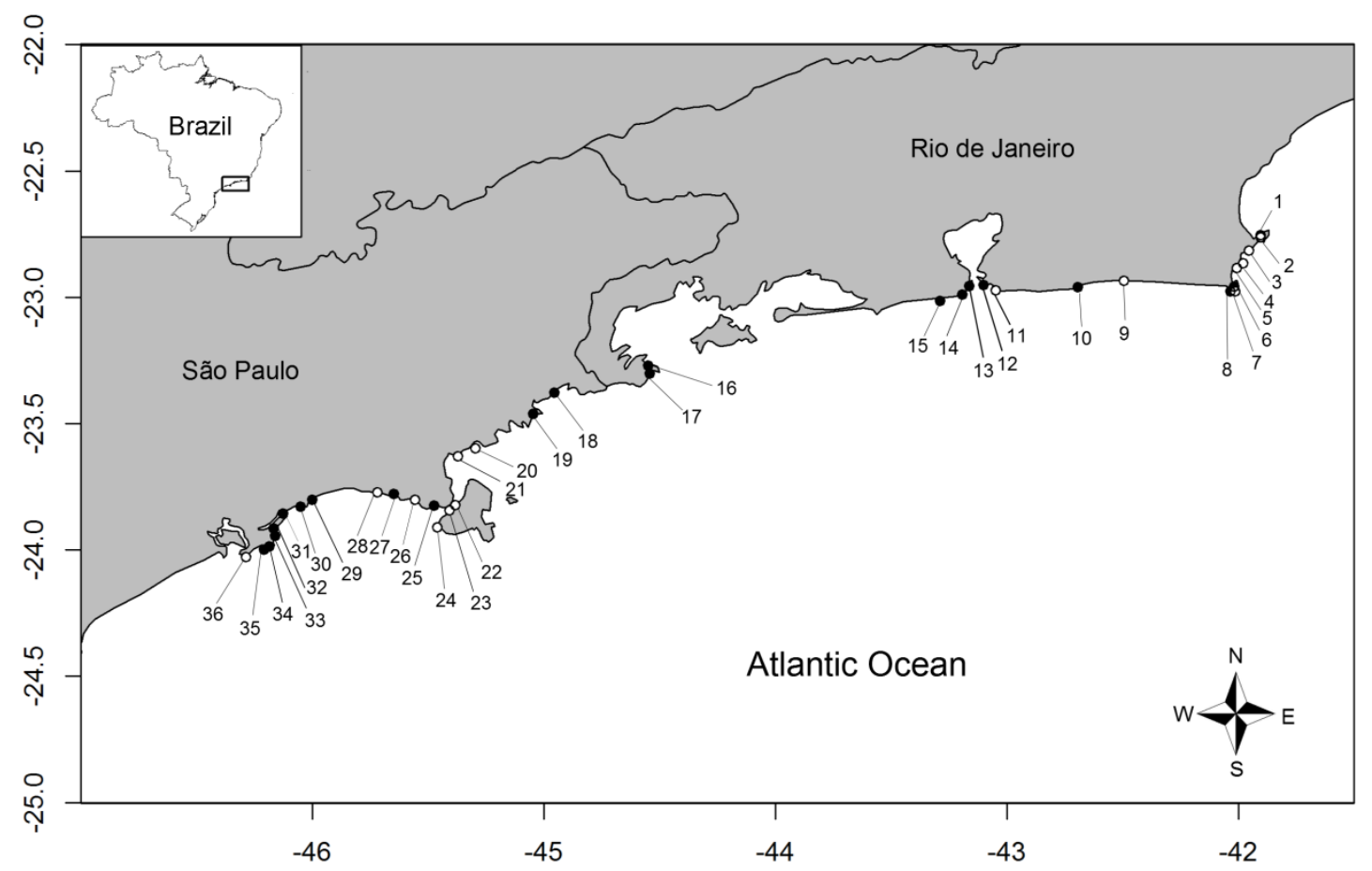

Figure 1. Map of the study region within the Southeastern coast of Brazil, indicating the location of sampled sites. Open circles indicate the sites included in multiple regression analyses. 1- Tartaruga; 2- Forno; 3- Caravelas; 4- Conchas-Perô; 5- Forte; 6- Prainha; 7Anjos; 8- Ponta da Cabeça; 9- Saquarema; 10- Ponta Negra; 11- Itaipu; 12- Piratininga; 13Praia Vermelha (RJ); 14- Arpoador; 15- Joatinga; 16- Pouso; 17- Ponta Rombuda; 18Prumirim; 19- Vermelha do Centro (SP); 20- Tamanduá Island; 21- Martim de Sá; 22Ilhabela Ferry; 23- Feiticeira; 24- Ponta Sul; 25- Guaecá; 26- Paúba; 27- Camburi; 28Juquehy; 29- São Lourenço; 30- Monte Pascoal; 31- Bertioga Channel; 32- Iporanga; 33Ponta do Vigia; 34- Éden, 35- Ponta do Santo Amaro; 36- Ponta do Gaiuba.

A shore stretch of 50-200 m was sampled at each site. Independent variables barnacle cover and average individual size were estimated from digital images (Nikon Coolpix ${ }^{\circledR}$ AW110; images processed using ImageJ software, Schneider et al. 2012) of $20 \mathrm{~cm}$ x $20 \mathrm{~cm} .10$ quadrats were haphazardly placed over the cirripede zone a few to several meters apart. Cover was estimated by overlapping grids over images and counting intersections (1 to 100) lying over living barnacles. Ten random individuals within each quadrat were also selected for estimates of average barnacle size. In order to avoid biased size estimates, individual barnacles were spotted along random gridlines and one out of three individuals was measured (maximum opercular length, $\pm 0.1 \mathrm{~mm}$ ). Reproductive 
effort was recorded in situ by examining macroscopically the development stage of gonads in three barnacle groups of 50 random individuals (within an area of ca. 5 $\mathrm{m}^{2}$ ), evenly spaced as to cover the full sampled stretch (making a total of 150 records per site). Brooding individuals were considered those bearing bright orange ovaries, compatible to stages 2 and 3, as described in 0'Riordan et al. (1995). No distinction between Chthamalus species were attempted, as the objective of this study was to explore possible factors acting on the density and reproductive output of chthamalid barnacles in general. Most of the sampled sites were exposed to fully marine nearshore conditions, but a few sites $(9,10,11,12,13,15,21,27,29$ and 31$)$ were relatively close to small river mouths and thus prone to wider variation of salinity. In Brazil, Chthamalus proteus populations are normally present on estuarine sites (Farrapeira 2008; Farrapeira 2010; Klôh et al. 2013), therefore, the results presented in this study should largely reflect dynamics of Chthamalus bisinuatus populations, but there might be some influence of processes affecting C. proteus, more locally.

The predictive variables measured in situ were the shore slope and the midshore height of the rocky shore (a proxy of insolation level and wave exposure respectively, e.g. Lewis 1964, Connell 1972). Five replicate measurements of these two variables were taken at regular intervals, covering the full sampled shore stretch. Slope was calculated from clinometer readings $\left( \pm 5^{\circ}\right)$. Midshore height, from the upper limit of red algal turfs to the upper limit of the main chthamalid zone, was estimated by adapting the bottle and tube method (Hawkins and Jones 1992), with bottle replaced by a second ruler as described in Flores et al. (2015).

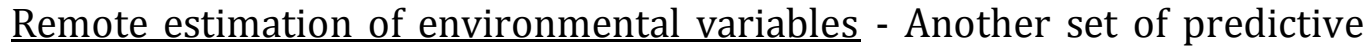
variables was obtained using images from Google Earth ${ }^{\circledR}$. All sampling sites were 
plotted on images of the Southeastern coast of Brazil and the distances from each sampling site to the closest sandy beach (a measure of sedimentation potential), river (a proxy of the influence of freshwater) and large urban areas ( $>20$ thousand inhabitants, a measure of potential human impact through water pollution) were recorded. Those images were also used to measure the extension of rocky shorelines where sampling sites were located, as a metric of habitat extension, which in turn, can be interpreted as a proxy of habitats stability. We assume that shorter habitats are prone to suffer from higher impacts from the surrounding conditions, like sand depositions for example. As these habitats are smaller, any change on the surrounding environment can promote changes over the entire population of such site. On more extent habitat, this changes can be diluted, as the larger size of such site reduces the impact over the populations established there. Also, the habitat extension can be seen as the potential for local recruitment, as larger rocky shores provides more space for settlement.

Data for environmental predictive variables were also obtained from satellite images. We used coincident global monthly Level-3 binned data products from September 2013 to December 2014 provided by the NASA Ocean Biology Processing Group (http://oceancolor.gsfc.nasa.gov), namely, sea surface temperature (SST), particulate organic carbon (POC), and chlorophyll-a (CHL) average concentrations. POC and CHL data are different proxies of food availability for barnacles. While POC provides data of biological detrital particles (Stramski et al. 2007), CHL provides data on the biomass of photosynthetic phytoplankton (Lorenzen 1966). Data were downloaded from the Moderate Resolution Imaging Spectroradiometer (MODIS) aboard the Aqua platform. The MODIS data were downloaded for the bin size about $4.6 \mathrm{~km} \times 4.6 \mathrm{~km}$. Then, MODIS data were 
analyzed using the R software (R Core Team, 2014) with the packages ncdf4 (Pierce, 2015), raster (Hijmans, 2015) and rgdal (Bivand et al., 2015).

Statistical analyses: We conducted multiple regression analyses to investigate probable relationships among each of the three response variables (barnacle density, percentage of individuals with developed eggs and average individual size) to a set of predictive variables. Before testing regression models, we checked collinearity among predictive variables. For that, a Pearson's correlation matrix was created in which all nine variables were correlated against each other. Significant correlation coefficients higher than 0.7 were consider evidence of strong collinearity. Collinear variables were then eliminated before further analyses, following the propositions of Dormann et al (2013). Then, the assumptions necessary to run multiple regression analyses (normality and homoscedasticity) were tested, and data were log transformed to meet these premises when needed.

Because we aimed a more exploratory assessment of possible processes ruling population dynamics and reproductive potential at random sites across a coastline, a linear backward stepwise multiple regression technique was chosen to obtain correlational evidence. Provided a significant $p$ value $(<0.05)$, we retained the model rendering the highest statistical $F$ value.

\section{Results}

After extracting data from satellite images, it was possible to obtain complete sets of CHL, POC and SST data for 21 locations (open circles in Fig. 1), used for further analyses. Before multiple regression analyses were performed, the 
coefficient of variation (CV) of all response and predictive variables were checked.

Table 1 provides the values obtained.

Table 1. Overall average and coefficient of variation (CV) estimates for independent and predictive variables across sampling sites $(n=21)$ used in multiple regression analyses. Units of variables are shown following its name.

\begin{tabular}{lccc}
\hline \multicolumn{1}{c}{ Response Variables } & Mean & Min/Max & CV(\%) \\
\hline $\begin{array}{l}\text { Individuals carrying } \\
\text { developed eggs (\%) }\end{array}$ & 41.3 & $4.6 / 86.6$ & 66.8 \\
Cover (\%) & 39.5 & $5.1 / 69$ & 52.0 \\
Average size & 0.25 & $0.17 / 0.4$ & 22.2 \\
(opercular length) (cm) & & & \\
& & & \\
$\quad$ Predictive Variables & & & \\
Slope (degrees) & 18.8 & $3 / 28$ & 31.3 \\
Height (m) & 1.0 & $0.54 / 2.0$ & 30.9 \\
Distance to large urban areas & & & \\
(m) & 30.8 & $6.2 / 64.9$ & 57.4 \\
Distance to beach (m) & 2.3 & $31.6 / 1850$ & 24.4 \\
Distance to river (m) & 3.4 & $54 / 46000$ & 25.7 \\
Habitat extension (m) & 3.2 & $55 / 18350$ & 21.0 \\
CHL (mg/m ${ }^{3}$ ) & 0.5 & $0.9 / 12.0$ & 57.7 \\
SST $\left({ }^{\circ} \mathrm{C}\right)$ & 22.0 & $17.4 / 24.8$ & 8.0 \\
& & $254.3 /$ & \\
POC (mg/m ${ }^{3}$ ) & 2.7 & 1481.2 & 8.0 \\
\hline
\end{tabular}

Among the response variables, the percentage of individuals carrying developed eggs and cover were the one varying the most, $66.8 \%$ and $52 \%$ respectively. Distance to harbor and CHL were the predictive variables with the highest CV values, $57 \%$ for both. Midshore height was the third most variable factor from the nine analyzed, showing a CV of 30\%. The parameters varying the most along the sampled coastline were also those that mattered the most in regression analyses, as it is shown ahead. 
Relationships between response variables - Results of correlation tests between barnacle variables, sampled across all the 36 sites examined, are summarized in table 2.

Table 2. Correlation coefficients between barnacle demographic and reproductive variables ( $r$ values), using data obtained for all 36 sites sampled. Significant correlations are highlighted in bold $(p<0.05)$.

\begin{tabular}{cccc}
\hline & $\begin{array}{c}\text { Individuals carrying } \\
\text { developed eggs (\%) }\end{array}$ & Cover (\%) & $\begin{array}{c}\text { Average size } \\
\text { (opercular } \\
\text { length) }\end{array}$ \\
\hline $\begin{array}{c}\text { Individuals carrying } \\
\text { developed eggs (\%) } \\
\text { Cover (\%) }\end{array}$ & $\mathrm{x}$ & 0.159 & $\mathbf{0 . 4 8 0}$ \\
Average size & & $\mathrm{x}$ & $\mathbf{0 . 6 5 9}$ \\
(opercular length) & & $\mathrm{x}$ \\
\hline
\end{tabular}

The percentage of individuals carrying developed eggs, here interpreted as a proxy of reproductive effort, was positively correlated with the average size of barnacles, indicating that size variation lies on a range affecting the relative proportion of the breeding population. Barnacle cover is also correlated positively with the average size of individuals, i.e. dense populations are constituted by larger animals.

Multiple regression analyses - Data of some variables needed to be logtransformed to meet homoscedasticity, and pairwise correlation analyses between predictive variables evidenced cases of collinearity, as indicated in Table 3 . 
Table 3. Pairwise correlation coefficients between predictive variables. Values in bold are statically significant $(\mathrm{p}<0.05)$ and indicated cases in which variables should be removed from further analyses.* indicates values that were log transformed.CHL= chlorophyll- $a$, SST= sea surface temperature, POC= particulate organic carbon.

\begin{tabular}{|c|c|c|c|c|c|c|c|c|c|}
\hline & Slope & $\begin{array}{c}\text { Midshore } \\
\text { Height }\end{array}$ & $\begin{array}{c}\text { Distance } \\
\text { to large } \\
\text { urban } \\
\text { areas* }\end{array}$ & $\begin{array}{c}\text { Distance } \\
\text { to } \\
\text { beach* }\end{array}$ & $\begin{array}{l}\text { Distance } \\
\text { to river* }\end{array}$ & $\begin{array}{c}\text { Habitat } \\
\text { extension* }\end{array}$ & $\mathrm{CHL}^{*}$ & SST & POC* \\
\hline Slope & $\mathrm{X}$ & 0.360 & -0.453 & 0.214 & 0.337 & 0.39 & 0.053 & $\begin{array}{c}0.235 \\
-\end{array}$ & 0.148 \\
\hline Height & & $\mathrm{x}$ & -0.067 & 0.047 & -0.079 & 0.294 & 0.304 & 0.052 & 0.372 \\
\hline $\begin{array}{l}\text { Distance to } \\
\text { large urban }\end{array}$ & & & $\mathbf{y}$ & 0043 & -0567 & - 103 & 201 & 0591 & -01 \\
\hline Distance to & & & $X$ & & & & & $\begin{array}{c}0.091 \\
-\end{array}$ & \\
\hline beach* & & & & $\mathrm{x}$ & 0.197 & 0.704 & -0.02 & 0.217 & -0.116 \\
\hline Distance to & & & & & & & & - & \\
\hline river* & & & & & $\mathrm{x}$ & 0.304 & 0.053 & 0.635 & -0.023 \\
\hline Habitat & & & & & & & & - & \\
\hline extension* & & & & & & $\mathrm{x}$ & 0.029 & $\begin{array}{c}0.393 \\
-\end{array}$ & 0.104 \\
\hline $\mathrm{CHL}^{*}$ & & & & & & & $\mathrm{x}$ & 0.337 & 0.866 \\
\hline SST & & & & & & & & $\mathrm{x}$ & -0.234 \\
\hline POC* $^{*}$ & & & & & & & & & $\mathrm{X}$ \\
\hline
\end{tabular}

The predictive variables kept in the final model were (i) rocky shore slope, (ii) midshore height, (iii) distance from large urban areas, (iv) SST, log transformed (v) distance from the closest beach,(vi) river, (vii) habitat extension and (viii) CHL. It was decided to maintain CHL and not POC, because CHL is a usual and most specific proxy for the concentration of phytoplankton (Falkowski et al. 1985; Stramski et al. 2007), which is a known as a main food source for filter feeding animals, such as the chthamalid barnacles (Wisley 1960; Helm et al. 2004).

Stepwise multiple regression analysis could not identify any models explaining the spatial variation of reproductive effort in the sampled barnacle populations, as estimated by the percentage of brooding individuals (Table 4). 
Differently, $42 \%$ of the spatial variability of barnacle cover was explained by a model retaining majority of dependent variables, except midshore height, distance to river and habitat extension (Table 4). Of those variables, distance from large urban areas and CHL concentration were statistically significant and rendered highest absolute $\beta$-coefficients. While a negative relationship in the former case indicates that sites closer large urban areas present higher chthamalid barnacle cover, the positive relationship in the latter case indicates that sites adjacent to coastal waters with higher CHL tend to host denser barnacle populations. $\beta$ coefficients and $p$-values indicate a higher relevance of distance to large urban areas, compared to CHL. Regression analyses also indicated factors affecting average barnacle size. In this case, a model retaining all but three parameters (slope, distance to beach, and SST), explained 38\% of the whole variance (Table 4). As for barnacle cover, CHL was statistically significant, positively correlated to barnacle size. Midshore height (a proxy for wave exposure) was also significant, but in this case negatively correlated to barnacle size, i.e. barnacles tend to be smaller in more exposed shores. For this response variable, $\beta$-coefficients and $p$ values suggest that $\mathrm{CHL}$ is a more important variable affecting barnacle size than wave exposure and/or heat stress. 
Table 4. Backward stepwise multiple regression results for the response variables: animals carrying eggs, animal cover and average size. Missing values indicate those variables which were removed from the final model for each response variable. Data obtained for 21 sites sampled.

\begin{tabular}{|c|c|c|c|c|c|c|}
\hline \multirow[b]{2}{*}{$\begin{array}{c}\text { Independent } \\
\text { Variables }\end{array}$} & \multicolumn{2}{|c|}{$\begin{array}{c}\text { Individuals carrying } \\
\text { eggs (\%) }\end{array}$} & \multicolumn{2}{|c|}{ Cover $(\%)$} & \multicolumn{2}{|c|}{ Average size } \\
\hline & $\begin{array}{c}\beta- \\
\text { coefficient }\end{array}$ & p-value & $\beta$ - coefficient & p-value & $\begin{array}{c}\beta- \\
\text { coefficient }\end{array}$ & p-value \\
\hline Slope & -0.119 & 0.729 & -0.347 & 0.103 & - & - \\
\hline $\begin{array}{l}\text { Midshore } \\
\text { Height }\end{array}$ & -0.047 & 0.881 & - & - & -0.448 & 0.039 \\
\hline $\begin{array}{l}\text { Distance to } \\
\text { large urban } \\
\text { areas }\end{array}$ & 0.287 & 0.466 & -0.750 & 0.007 & -0.457 & 0.055 \\
\hline $\begin{array}{l}\text { Distance to } \\
\text { beach }\end{array}$ & -0341 & 0.379 & 0.354 & 0.07 & - & - \\
\hline $\begin{array}{l}\text { Distance to } \\
\text { river }\end{array}$ & 0.333 & 0.381 & - & - & -0.270 & 0.260 \\
\hline $\begin{array}{l}\text { Habitat } \\
\text { extension }\end{array}$ & 0.285 & 0.523 & - & - & 0.341 & 0.106 \\
\hline CHL & 0.108 & 0.719 & 0.431 & 0.03 & 0.540 & 0.011 \\
\hline SST & -0.209 & 0.623 & 0.247 & 0.306 & - & - \\
\hline & $\begin{array}{l}F(8,12)= \\
0.444\end{array}$ & $\begin{array}{c}\mathrm{p}< \\
0.872\end{array}$ & $\begin{array}{l}R^{2}=0.416 \\
F(5,15)=3.860\end{array}$ & $\begin{array}{l}p= \\
0.018\end{array}$ & $\begin{array}{l}\mathrm{R}^{2}=0.382 \\
\mathrm{~F}(5,15)= \\
3.478\end{array}$ & $\begin{array}{l}p= \\
0.027\end{array}$ \\
\hline
\end{tabular}

\section{Discussion}

Barnacles have long been used as a biological model for understanding coastal ecological processes. The sessile adult form and complex life cycle makes them a good predictor of benthic-pelagic relationships. Among all barnacles, populations of the Chthamalus genus are particularly interesting, due to its worldwide distribution and the fact that these organisms inhabit the highest part of the intertidal, been able to survive and reproduce under harsh environmental conditions. For this matter it becomes important to better understand some key aspects of its population biology, including reproductive and demographic traits and its relationship with coastal oceanographic conditions. This study presents for 
the first time in a subtropical coast exploratory data concerning environmental factors linked to demographic and reproductive traits of chthamalid barnacles. The population traits considered here, i.e, adults average size, cover percentage and individuals carrying developed eggs, were correlated among themselves, with food supply and wave exposure or heat stress as the main environmental variables explaining the demographic traits of chthamalid barnacles in the Southeastern coast of Brazil.

Coastal waters in upwelling regions are often very productive, and characterized by high densities of phytoplanktonic cells (Dugdale 1972; Kokkinakis and Wheeler 1987). Compared to non-upwelling rocky coasts, this additional supply of pelagic resources may sustain larger secondary production of intertidal filter-feeding invertebrates, including barnacles and mussels, and thus profoundly alter general community dynamics in this ecosystem (Gaines et al. 2003; Phillips 2005; Leslie et al. 2005). Among all sites studied here, the few located around Arraial do Cabo, RJ, a well-known upwelling area in the region, contributed for the mesoscale spatial heterogeneity of CHL estimates, which rendered a recognizable signature in barnacle populations. Also, Guanabara and Sepetiba bays at RJ and Santos bay at SP, can enhance primary productivity by discharge of nutrients that leads to the growth of phytoplankton cells, which might also contribute for variations of CHL along the coast (Takanohashi et al. 2014). Not only the previously mentioned bays are a source of nutrient due to its estuarine conditions, these sites present large urban pollution discharge which can act as an unnatural source of nutrient for primary producers (Kjerfve et al. 1997; Schmiegelow et al. 2008; Giordano et al. 2013; Takanohashi et al. 2014). As suspected, we found positive relation of average size and CHL throughout our 
survey, demonstrating the impact of food supply for barnacle growth and maintenance.

Barnacles that inhabit regions with higher temperatures tend to present higher metabolic rates, which results in higher feeding activities to fulfill the energetic requirements (Anderson 1994). Also, elevated food availability provides elevated energetic reserves, as the energy dispended for feeding is reduced, as organisms spend less energy searching for it (Navarro and Thompson 1996). Temperature data obtained for this study showed little variation, which allows the assumption that this is a stable factor across the sampled region and, therefore, barnacles should be subjected to similar thermal stress. Under such scenario, it is plausible to assume that these chthamalid barnacles, which are exposed to elevated temperatures at the study region, can accumulate more energy at sites with higher food concentration and allocate more energy for growth, resulting in larger individual size. Furthermore, although this was not tested directly in our survey, it is generally known that larger animals tend to produce more eggs (Burrows et al. 1992; Leslie 2005). Thus, we could expect to observe a higher reproductive output at sites with higher phytoplankton concentrations, characterizing such places as "hotspots" for chthamalid barnacle reproduction. In our survey adult size was the most important variable affecting overall reproductive output, since this was the only variable significantly correlated to the percentage of animals carrying developed eggs. Positive relationships between adult size and reproductive effort has already been demonstrated for some chthamalid species from temperate regions (Burrows et al. 1992), and our results suggests the same pattern at the sub-tropical region studied. 
In open marine systems, such as barnacle populations, density-dependent processes are known for regulating the stability of adult populations (Hixon et al. 2002). At one side, great densities might enhance overall fitness of adults by different mechanisms, such as dilution of predation, increased availability of partners, collective environmental modifications that reduces physical stress and others (Stephens et al. 1999). These so called "Allee effects" have already been detected in barnacle populations (Wethey 1984; Bertness et al. 1998; Leslie 2005). But at the other side, negative effects on overall fitness can also arise from higher densities, because it increases competition for resources, decreases energy assimilation and growth potential (Wu 1980; Bruno et al. 2003). With this in mind, one could expect to observe more breeding individuals at higher densities through "Allee effects", but this was not the case, as no correlation between these two variables could be observed in our survey. It seems that brooding is mostly driven by stochastic variation affected by parameters not quantified in this study. Also, it could be expected to observe smaller animals at higher densities, as a consequence of lower growth potential due to competition for space. Again, this was not the case, as we observed a strong, positive correlation between barnacle cover percentage and average size. Unlike other species, chthamalid barnacles along the surveyed Brazilian coast can reach larger sizes on population that have higher densities, an opposite pattern of what has already been described for other barnacles (Wu 1980; Leslie 2005). This trend could be explained by the fact that higher densities could alter the surrounding environment of these populations to better survival conditions (Bertness et al. 1998), enhancing growth potential until a threshold size, and thus, maintaining a stable dense population of larger individuals. 
Barnacles average size was not explained only by cover percentage. CHL concentration and midshore height (= wave exposure) explained part of all variance in size. The negative relationship between average size and wave action indicates that at more wave-swept sites, chthamalid barnacles tend to be smaller. Midshore height is a proxy of exposure because fouling assemblages spread vertically as additional spray and splash allow them to stand at places where they would otherwise desiccate. At such conditions, one could expect to observe larger barnacles, as the elevated water flux at these sites would deliver greater food supply for filter-feeders (Sanford et al. 1994; Leonard et al. 1998). But this was not the case of our results. One possible interpretation of our results is that lower average size is a consequence of higher recruitment rates at exposed sites (Bustamante and Branch 1996; Pfaff et al. 2011), leading to habitat saturation, increased competition for space, and stunted growth to a certain size (López and González 2003). Although SST was stable along the sampling sites, leading us to assume that all barnacle populations were under the influence of similar temperature conditions, we could not measure the potential effect of air temperature on such populations, neither the potential heat stress that chthamalid on different rocky shore heights are submitted to.

Barnacle cover was explained by two environmental factors: CHL concentration and the distance from large urban areas. Both factors are related to the same biological information, food supply. Large urban areas considered in this study (presenting over 20 thousand inhabitants) are sites of great eutrophication due to pollution discharge in near shore waters, as in other places around the world (Kjerfve et al. 1997; Bonetti et al. 2000; Braga et al. 2000; Moser et al. 2004; Giordano 2008), where primary productivity is very high, leading to very high 
phytoplankton standing stocks. Nevertheless, we did not observe a strong relationship between distance from large urban areas and CHL or POC content, indicating that these food sources are not abundant in such sites. Although we did not measure it, dissolved organic and inorganic matter could be responsible for the observed relation between barnacle cover and distance from large urban areas. Past studies have demonstrated the role of dissolved matter on marine invertebrate nutrition (Wotton 1988; Wendt and Johnson 2006). The relationship between cover percentage and CHL concentrations was positive, indicating that the more densely populated sites are those with higher phytoplankton concentrations. CHL concentrations has long been used as a proxy of phytoplankton concentrations, a known food source for filter feeding animals (Barnes 1972; Menge et al. 1997; Sanford and Menge 2001). Regarding the distance from large urban areas, the relationship observed was negative, indicating that chthamalid populations further away from these urban areas, and consequently further from high food concentrations, are least dense. So food supply not only benefits barnacle growth but also its establishment at the rocky shore. Knowing the importance of food supply for both larval supply (Pechenik et al. 2002; Toupoint et al. 2012) and recruitment success (Phillips 2004; Cole et al. 2011; Griffith et al. 2011), our hypothesis is that higher food concentrations, for both larvae and benthic juveniles, enhances the settlement and recruitment success in this group of barnacles, leading to higher densities at site with higher food supply, a trend already observed for other barnacles (Sanford et al. 1994).

Although many aspects of chthamalid barnacle populations biology has already been studied, most of the data published so far concerns species from temperate regions, and little is known about the regional distribution and 
maintenance of tropical species. Here we present for the first time evidence of the role of food availability for density and growth of chthamalid barnacles. Our results indicates a possible "bottom-up" control (Menge et al. 1997; Menge et al. 2002; Leslie et al. 2005a) of these populations, with primary producers influencing the abundance and performance of filter feeding animals, such as these barnacles. However, it should be stressed that the evidenced presented here is strictly correlational. Experimental work should follow to more properly and specifically test the mechanisms proposed here. 


\section{Bibliography}

Aguiar V, Braga E (2007) Seasonal and tidal variability of phosphorus along a salinity gradient in the heavily polluted estuarine system of Santos/São Vicente - São Paulo, Brazil. Mar Pollut Bull 54:464-471. doi: 10.1016/j.marpolbul.2006.11.001

Allen R, Buckley Y, Marshall D (2008) Offspring Size Plasticity in Response to Intraspecific Competition: An Adaptive Maternal Effect across Life- History Stages. Am Nat 171:225-237. doi: 10.1086/524952

Anderson D (1994) Barnacles - Structure, function, development and evolution.

Anger K (2001) The biology of decapod crustacean larvae.

Anger K, Dawris R (1981) Influence of starvation on the larval development of Hyras araneus (Decapoda, Majidae). Helgolander Meeresuntersuchungen 34:287-311.

Anil A, Desai D, Khandeparker L (2001) Larval development and metamorphosis in Balanus amphitrite Darwin (Cirripedia; Thoracica): significance of food concentration, temperature and nucleic acids. J Exp Mar Bio Ecol 263:125-141. doi: 10.1016/S0022-0981(01)00280-5

Anil A, Kurian J (1996) Influence of food concentration, temperature and salinity on the larval development of Balanus amphitrite. Mar Biol 127:115-124. doi: 10.1007/BF00993651

Arrontes J, Arenas F, Fernández C, et al (2004) Effect of grazing by limpets on midshore species assemblages in northern Spain. Mar Ecol Prog Ser 277:117-133. doi: $10.3354 /$ meps 277117

Barbosa A, Gomes C, Pereira G, et al (2016) Local biological drivers, not remote forcing, predict settlement rate to a subtropical barnacle population. Mar Ecol Prog Ser. doi: $10.3354 /$ meps 11589

Barnes H (1972) The seasonal changes in body weight and biochemical composition of the warm-temperate cirripede Chthamalus stellatus(Poli). J Exp Mar Bio Ecol 8:89-100.

Barnes H, Barnes M (1965) Egg size, nauplius size, and their variation with local, geographical, and specific factors in some common cirripedes. J Anim Ecol 34:391-402.

Barnes H, Barnes M (1968) Egg numbers, metabolic efficiency of egg production and fecundity; local and regional variations in a number of common cirripedes. J Mar Biol Ecol 2:135-153.

Barnes H, Barnes M (1959) A comparison of the annual growth patterns of Balanus balanoides (L.) with particular reference to the effect of food and temperature. Oikos 10:1-18.

Barnes H, Crisp D (1956) Evidence of self-fertilization in certain species of barnacles. J Mar Biol Assoc UK 35:631-639.

Barnes M (1989) Egg production in cirripedes. Oceanography and Marine Biology: an Annual Review. pp 91-166

Basch L, Pearse J (1995) Consequences of larval feeding environment for settlement and metamorphosis of a temperate echinoderm. Oceanol acta 19:273-285.

Bay L, Buechler K, Gagliano M, Caley M (2006) Intraspecific variation in the pelagic larval duration of tropical reef fishes. J Fish Biol 68:1206-1214. doi: 10.1111/j.0022-1112.2006.01016.x

Beckerman A, Benton T, Lapsley C, Koesters N (2006) How effective are maternal effects at having effects? Proc R Soc B 273:485-93. doi: 10.1098/rspb.2005.3315

Benedetti-Cecchi L (2000) Predicting Direct and Indirect Interactions during Succession in a Mid-Littoral Rocky Shore Assemblage. Ecol Monogr 70:45-72. 
Benkendorfer G, Soares-Gomes A (2009) Biogeography and biodiversity of gastropod molluscs from the eastern Brazilian continental shelf and slope. Lat Am J Aquat Res 37:143-159. doi: 10.3856/vol37-issue2-fulltext-3

Berkeley S, Chapman C, Sogard S (2004) Maternal Age as a Determinant of Larval Growth and Survival in a Marine Fish, Sebastes melanops. Ecology 85:12581264.

Bernardo J (1996) Maternal effects in animal ecology. Am Zool 36:83-105.

Bertness M (1989) INTRASPECIFIC COMPETITION AND FACILITATION IN A NORTHERN ACORN BARNACLE POPULATION '. Ecology 70:257-268.

Bertness M, Gaines S, Bermudez D, Sanford E (1991) Extreme spatial variation in the growth and reproductive output of the acorn barnacle Semibalanus balanoides. Mar Ecol Prog Ser 75:91-100. doi: 10.3354/meps075091

Bertness M, Gaines S, Stephens E, Yund P (1992) Components of recruitment in populations of the acorn barnacle Semibalanus balanoides (Linnaeus). J Exp Mar Bio Ecol 156:199-215. doi: 10.1016/0022-0981(92)90246-7

Bertness M, Gaines S, Yeh S (1998) Making Mountains out of Barnacles : The Dynamics of Acorn Barnacle Hummocking. Ecology 79:1382-1394.

Bertram D, Strathmann R (1998) Effects of maternal and larval nutrition on growth and form of planktotrophic larvae. Ecology 79:315-327.

Bingham B (1992) Life Histories in an Epifaunal Community : Coupling of Adult and Larval Processes. Ecology 73:2244-2259.

Bivand R, Keitt T, Rowlingson B (2015) rgdal: Bindings for the Geospatial Data AbstractionLibrary. R package version 1.1-3.

Boidron-Metairon I (1988) Morphological plasticity in laboratory-reared echinoplutei of Dendraster excentricus (Eschscholtz) and Lytechinus variegatus (Lamarck) in response to food conditions. J Exp Mar Bio Ecol 119:31-41. doi: 10.1016/00220981(88)90150-5

Bolton T, Havenhand J (2005) Physiological acclimation to decreased water temperature and the relative importance of water viscosity in determining the feeding performance of larvae of a serpulid polychaete. J Plankton Res 27:875879. doi: 10.1093/plankt/fbi060

Bonetti C, Bonetti Filho J, Braga E (2000) INTEGRATION OF BIOLOGICAL, RADIOMETRIC AND CHEMICAL-ANALYTIC METHODOLOGIES TO THE ASSESSMENT OF ESTUARINE. Sustainable use of estuaries and mangroves: Challenges and prospects.

Botello G, Krug P (2006) 'Desperate larvae' revisited: age, energy and experience affect sensitivity to settlement cues in larvae of the gastropod Alderia sp. Mar Ecol Prog Ser 312:149-159. doi: 10.3354/meps312149

Braga E, Bonetti C, Burone L, Bonetti Filho J (2000) Eutrophication and Bacterial Pollution Caused by Industrial and Domestic Wastes at the Baixada Santista Estuarine System - Brazil. Mar Pollut Bull 40:165-173. doi: 10.1016/S0025326X(99)00199-X

Bruno J, Stachowicz J, Bertness M (2003) Inclusion of facilitation into ecological theory. Trends Ecol Evol 18:119-125. doi: 10.1016/S0169-5347(02)00045-9

Bueno M, Moser G, Tocci B, Flores A (2010) Retention-favorable timing of propagule release in barnacles and periwinkles. Mar Ecol Prog Ser 414:155-165. doi: 10.3354/meps08715

Burrows M, Hawkins S, Southward A (1992) A comparison of reproduction in cooccurring chthamalid barnacles, Chthamalus stellatus (Poli) and Chthamalus montagui Southward. J Exp Mar Bio Ecol 160:229-249. doi: 10.1016/0022- 
0981(92)90240-B

Bustamante R, Branch G (1996) Large scale patterns and trophic structure of southern African rocky shores: the role of geographic variation and wave exposure. $\mathrm{J}$ Biogeogr 23:339-351. doi: 10.1046/j.1365-2699.1996.00026.x

Caley M, Carr M, Hixon M, et al (1996) Recruitment and the local dynamics of open marine populations. Annu Rev Ecol Evol Syst 27:477-500. doi:

10.1146/annurev.ecolsys.27.1.477

Carpenter S (1988) Complex Interactions in Lake Communities.

Ciotti Á, Garcia C, Jorge D (2010) Temporal and meridional variability of Satelliteestimates of surface chlorophyll concentration over the Brazilian continental shelf. Pan-American J ... 5:236-253.

Cole SW, Scrosati R, Tam J, Sussmann A (2011) Regional decoupling between NW Atlantic barnacle recruit and adult density is related to changes in pelagic food supply and benthic disturbance. J Sea Res 65:33-37. doi: $10.1016 /$ j. seares.2010.06.006

Connell J (1985) The consequences of variation in initial settlement vs. post-settlement mortality in rocky intertidal communities. J Exp Mar Bio Ecol 93:11-45. doi: 10.1016/0022-0981(85)90146-7

Connell J (1961a) The influence of interspecific competition and other factors on the distribution of the barnacle Chthamlaus stellatus. Ecology 42:235-254.

Connell J (1961b) Effects of competition, predation by Thais lapillus, and other factors on natural populations of the barnacle Balanus balanoides. Ecol Monogr 31:61104.

Connell J (1972) Community Interactions on MarineCommunity Interactions on Marine Rocky Intertidal Shores. Annu Rev Ecol Syst 3:169-192.

Crean A, Marshall D (2009) Coping with environmental uncertainty: dynamic bet hedging as a maternal effect. Philos Trans R Soc Lond B Biol Sci 364:1087-1096. doi: $10.1098 /$ rstb.2008.0237

Cushing D (1990) Plankton production and year-class strength in fish populations: an update of the match/mismatch hypothesis. Adv Mar Biol 249-293.

Dando P, Southward A (1980) A new species of Chthamalus (Crustacea: Cirripedia) characterized by enzyme electrophoresis and shell morphology: with a revision of other species of Chthamalus from the western shores of the atlantic ocean. J Mar Biol Assoc United Kingdom 60:787. doi: 10.1017/S0025315400040455

Desai D, Anil A, Venkat K (2006) Reproduction in Balanus amphitrite Darwin (Cirripedia: Thoracica): influence of temperature and food concentration. Mar Biol 149:1431-1441. doi: 10.1007/s00227-006-0315-3

Diss A, Kunkel J, Montgomery M, Leonard D (1996) Effects of maternal nutrition and egg provisioning on parameters of larval hatch, survival and dispersal in the gypsy moth, Lymantria dispar L. Oecologia 106:470-477. doi: 10.1007/BF00329704

Dixon P, Milicich M, Sugihara G (1999) Episodic Fluctuations in Larval Supply. Science (80- ) 283:1528-1530. doi: 10.1126/science.283.5407.1528

Dormann C, Elith J, Bacher S, et al (2013) Collinearity: A review of methods to deal with it and a simulation study evaluating their performance. Ecography (Cop) 36:027-046. doi: 10.1111/j.1600-0587.2012.07348.x

Dugdale R (1972) Chemical Oceanography and Primary Productivity in Upwelling Regions.

Dungan M (1986) Three-Way Interactions: Barnacles, Limpets and Algae in a Sonoran Desert Rocky Intertidal Zone. Am Nat 127:292-316. doi: 10.1086/284486

Falkowski P, Dubinsky Z, Santostefano G (1985) Light-enhanced dark respiration in 
phytoplankton. Verh Internat Verein Limnol 22:2830-2833.

Farrapeira C (2010) Shallow water Cirripedia of the northeastern coast of Brazil: The impact of life history and invasion on biogeography. J Exp Mar Bio Ecol 392:210 219. doi: $10.1016 /$ j.jembe.2010.04.021

Farrapeira C (2008) Cirripedia Balanomorpha del estuario del Río Paripe (Isla de Itamaracá, Pernambuco, Brasil). Biota Neotrop 8:31-39. doi: 10.1590/S167606032008000300002

Fenaux L, Strathmann M, Strathmann R (1994) Five tests of food-limited growth of larvae in coastal waters by comparisons of rates of development and form of echinoplutei. Limnol Oceanogr 39:84-98. doi: 10.4319/lo.1994.39.1.0084

Floeter S, Soares-Gomes A (1999) Biogeographic and Species Richness Patterns of Gastropoda on the Southwestern Atlantic. Rev Bras Biol 59:567-575.

Flores A, Christofoletti R, Peres A, et al (2015) Interactive effects of grazing and environmental stress on macroalgal biomass in subtropical rocky shores: Modulation of bottom-up inputs by wave action. J Exp Mar Bio Ecol 463:39-48. doi: 10.1016/j.jembe.2014.11.001

Foster B (1987) Barnacle ecology and adaptation. Barnacle Biology. pp 113 - 133

Foster B (1971a) Desiccation as a factor in the intertidal zonation of barnacles. Mar Biol 8:12-29. doi: 10.1007/BF00349341

Foster B (1971b) On the determinants of the upper limit of intertidal distribution of barnacles (Crustacea: Cirripedia). J Anim Ecol 40:33-48. doi: 10.2307/3328

Fox C, Thakar M, Mousseau T (1997) The Evolutionary Genetics of an Adaptive Maternal Effect : Egg Size Plasticity in a Seed Beetle. 149:149-163.

Freuchet F, Tremblay R, Flores A (2015) Interacting environmental stressors modulate reproductive output and larval performance in a tropical intertidal barnacle. Mar Ecol Prog Ser 532:161-175. doi: 10.3354/meps11377

Gaeta S, Ribeiro S, Metzler P, et al (1999) Environmental forcing on phytoplankton biomass and primary productivity of the coastal ecosystem in Ubatuba region, southern Brazil. Rev Bras Oceanogr 47:11-27.

Gagliano M, McCormick M (2007) Maternal condition influences phenotypic selection on offspring. J Anim Ecol 76:174-182. doi: 10.1111/j.1365-2656.2006.01187.x

Gaines S, Brown S, Roughgarden J (1985) Spatial variation in larval concentrations as a cause of spatial variation in settlement for the barnacle, Balanus glandula. Oecologia 67:267-272. doi: 10.1007/BF00384297

Gaines S, Hudson G, Krenz C, et al (2003) Coastal oceanography sets the pace of rocky intertidal community dynamics. Proc Natl Acad Sci U S A 100:12229-12234. doi: 10.1073/pnas. 1534875100

Gaines S, Roughgarden J (1985) Larval settlement rate: A leading determinant of structure in an ecological community of the marine intertidal zone. Proc Natl Acad Sci U S A 82:3707-11.

Garrabou J, Coma R, Bensoussan N, et al (2009) Mass mortality in Northwestern Mediterranean rocky benthic communities: Effects of the 2003 heat wave. Glob Chang Biol 15:1090-1103. doi: 10.1111/j.1365-2486.2008.01823.x

Garrabou J, Perez T, Sartoretto S, Harmelin J (2001) Mass mortality event in red coral Corallium rubrum populations in the Provence region (France, NW Mediterranean). Mar Ecol Prog Ser 217:263-272. doi: 10.3354/meps217263

Gianesella S, Kutner M, Saldanha-Corrêa F, Pompeu M (1999) Assessment of plankton community and environmental conditions in São Sebastião Channel prior to the construction of a produced water outfall. Rev Bras Oceanogr 47:29-46.

Giordano F (2008) Zoobenthos of the Santos estuarine system. PERSPECTIVES ON 
INTEGRATED COASTAL ZONE MANAGEMENT IN SOUTH AMERICA.

Giordano F, Borges R, Santos J, Rosso S (2013) Recrutamento e colonização de cirripédios Balanus trigonus em painéis artificiais em águas estuarinas de SantosSP , Brasil : um estudo de 45 meses . Cirriped Balanus trigonus colonization and recruitment in artificial panels in estuarine waters in Santos. Bioscience 2:35-41.

Gosselin L, Chia F (1996) Prey selection by inexperienced predators: Do early juvenile snails maximize net energy gains on their first attack? J Exp Mar Bio Ecol 199:4558. doi: 10.1016/0022-0981(95)00190-5

Gosselin L, Qian P (1996) Early post-settlement mortality of an intertidal barnacle: a critical period for survival. Mar Ecol Prog Ser 135:69-75.

Griffith K, Giménez L, Jenkins S (2011) Climate driven changes in recruitment success of marine invertebrates: The role of food supply . ICES CM 2011.

Guenther M, Gonzalez-Rodriguez E, Carvalho W, et al (2008) Plankton trophic structure and particulate organic carbon production during a coastal downwellingupwelling cycle. Mar Ecol Prog Ser 363:109-119. doi: 10.3354/meps07458

Guiler E (1955) Australian Intertidal Belt-Forming Species in Tasmania. J Ecol 43:138148.

Harley C (2006) Effects of physical ecosystem engineering and herbivory on intertidal community structure. Mar Ecol Prog Ser 317:29-39. doi: 10.3354/meps317029

Harley C (2008) Tidal dynamics, topographic orientation, and temperature-mediated mass mortalities on rocky shores. Mar Ecol Prog Ser 371:37-46. doi: 10.3354/meps07711

Hawkins S, Jones H (1992) Rocky Shores (Vol. 1).

Helm M, Bourne N, Lovatelli A (2004) Hatchery culture of bivalves: A practical manual. Rome

Helmuth B, Broitman B, Blanchette C, et al (2006) Mosaic Patterns of Thermal Stress in the Rocky Intertidal Zone: Implications for Climate Change. Ecol Monogr 76:461-479. doi: 10.1890/0012-9615(2006)076[0461:MPOTSI]2.0.CO;2

Helmuth BS, Hofmann GE (2001) Microhabitats, thermal heterogeneity, and patterns of physiological stress in the rocky intertidal zone. Biol Bull 201:374-84.

Hentschel B, Emlet R (2000) Metamorphosis of barnacle nauplii: effects of food variability and a comparison with amphibian models. Ecology 81:3495-3508.

Hijmans R (2015) No Title raster: Geographic Data Analysis and Modeling. R package version 2.5-2.

Hines A (1978) Reproduction in three species of intertidal barnacles from central California. Biol Bull 154:262-281.

Hixon M, Pacala S, Sandin S (2002) Population regulation: historical context and contemporary challenges of open vs. closed systems. Ecology 83:1490-1508. doi: 10.1890/0012-9658(2002)083[1490:PRHCAC]2.0.CO;2

Hu C, Lee Z, Franz B (2012) Chlorophyll a algorithms for oligotrophic oceans: A novel approach based on three-band reflectance difference. J Geophys Res Ocean 117:125. doi: 10.1029/2011JC007395

Hughes T, Baird A, Dinsdale E, et al (2000) Supply-Side Ecology Works Both Ways: The Link between Benthic Adults, Fecundity, and Larval Recruits. Ecology 81:2241-2249. doi: 10.2307/177111

Hutchins L (1947) The bases for temperature zonation in geographical distribution. Ecol Monogr 17:325-335. doi: 10.2307/1948663

Jarrett J (2003) Seasonal Variation in Larval Condition and Postsettlement Performance of the Barnacle Semibalanus Balanoides. Ecology 84:384-390. doi: 10.1890/00129658(2003)084[0384:SVILCA]2.0.CO;2 
Jarrett J, Pechenik J (1997) Temporal Variation in Cyprid Quality and Juvenile Growth Capacity for an Intertidal Barnacle. Ecology 78:1262-1265. doi: 10.1890/00129658(1997)078[1262:TVICQA]2.0.CO;2

Jenkins S (2005) Larval habitat selection, not larval supply, determines settlement patterns and adult distribution in two chthamalid barnacles. J Anim Ecol 74:893904. doi: 10.1111/j.1365-2656.2005.00985.x

Jonsson P, Berntsson K, Larsson A (2004) Linking Larval Supply To Recruitment: Flow-Mediated Control of Initial Adhesion of Barnacle Larvae. Ecology 85:2850 2859. doi: 10.1890/03-0565

Kasten P, Flores A (2013) Disruption of endogenous tidal rhythms of larval release linked to food supply and heat stress in an intertidal barnacle. Mar Ecol Prog Ser 472:185-198. doi: 10.3354/meps10005

Kjerfve B, Ribeiro C, Dias G, et al (1997) Oceanographic characteristics of an impacted coastal bay: Baía de Guanabara, Rio de Janeiro, Brazil. Cont Shelf Res 17:16091643. doi: 10.1016/S0278-4343(97)00028-9

Klôh A, Farrapeira C, Rigo A, Rocha R (2013) Intertidal native and introduced barnacles in Brazil: distribution and abundance. Mar Biodivers Rec 6:e102. doi: 10.1017/S1755267213000766

Kokkinakis S, Wheeler P (1987) Nitrogen uptake and phytoplankton growth in coastal upwelling regions. Limnol Oceanogr 32:1112-1123. doi: 10.4319/lo.1987.32.5.1112

Krug P (2001) Bet-hedging dispersal strategy of a specialist marine herbivore: A settlement dimorphism among sibling larvae of Alderia modesta. Mar Ecol Prog Ser 213:177-192. doi: 10.3354/meps 213177

Lang W, Marcy M (1982) SOME EFFECTS OF EARLY STARVATION ON THE SURVIVAL IMPROVISUS. J Exp Mar Bio Ecol 60:63-70.

Leonard G, Levine J, Schmidt P, Bertness M (1998) Flow-Driven Variation in Intertidal Community Structure in a Maine Estuary. Ecology 79:1395-1411. doi: $10.2307 / 176751$

Leslie H (2005) Positive intraspecific effects trump negative effects in high-density barnacle aggregations. Ecology 86:2716-2725. doi: 10.1890/04-1767

Leslie H, Breck E, Chan F, et al (2005a) Barnacle reproductive hotspots linked to nearshore ocean conditions. Proc Natl Acad Sci U S A 102:10534-9. doi: 10.1073/pnas.0503874102

Leslie H, Breck E, Chan F, et al (2005b) Barnacle reproductive hotspots linked to nearshore ocean conditions. Proc Natl Acad Sci U S A 102:10534-10539. doi: 10.1073/pnas.0503874102

Letcher B, Rice J, Crowder L, Rose K (1996) Variability in survival of larval fish: disentangling components with a generalized individual-based model. Can J Fish Aquat Sci 53:787-801. doi: 10.1139/f95-241

Lewis J (1964) The ecology of rocky shores.

Longhurst A (1998) Ecological and Geography of the Sea.

López D, González M (2003) Density-dependent effects in Jehlius cirratus (Darwin, 1854) (Cirripedia: Chthamalidae) under different growth conditions. Mar Ecol 24:289-302. doi: 10.1046/j.1439-0485.2003.00851.x

López M, Coutinho R (2008) Acoplamento Plâncton-Bentos: O Papel Do Suprimento Larval Na Estrutura Das Comunidades Bentônicas De Costões Rochosos. Oecologia Bras 12:575-601. doi: 10.4257/oeco.2009.1204.01

Lorenzen C (1966) A method for the continuous measurement of in vivo chlorophyll concentration. Deep Sea Res Oceanogr Abstr 13:223-227. doi: 10.1016/0011- 
7471(66)91102-8

Marshall D, Bolton T, Keough M (2003) Offspring size affects the post-metamorphic performance of a colonial marine invertebrate. Ecology 84:3131-3137.

Marshall D, Bonduriansky R, Bussière L (2008) Offspring size variation within broods as a bet-hedging strategy in unpredictable environments. Ecology 89:2506-2517.

Marshall D, Keough M (2004) When the going gets rough: effect of maternal size manipulation on larval quality. Mar Ecol Prog Ser 272:301-305. doi: $10.3354 /$ meps 272301

Marshall J, Uller T (2007) When is a maternal effect adaptive? Oikos 116:1957-1963. doi: 10.1111/j.2007.0030-1299.16203.x

Mcclintock J, Stephen A (1990) The effects of photoperiod on gametogenesis in the tropical sea urchin Eucidaris tribuloides ( Lanmrck ) ( Echinodermata : Echinoidea ). J Exp Mar Bio Ecol 139:175-184.

Menge B a, Olson AM, Dahlhoff EP (2002) Environmental Stress, Bottom-up Effects, and Community Dynamics: Integrating Molecular-Physiological and Ecological Approaches. Integr Comp Biol 42:892-908. doi: 10.1093/icb/42.4.892

Menge B, Daley B, Wheeler P, et al (1997) Benthic-pelagic links and rocky intertidal communities: bottom-up effects on top-down control? Proc Natl Acad Sci U S A 94:14530-14535. doi: 10.1073/pnas.94.26.14530

Metzler P, Glibert P, Gaeta S, Ludlam J (1997) New and regenerated production in the South Atlantic off Brazil. Deep Res I 44:363-384.

Miller S, Morgan S (2013) Phenotypic plasticity in larval swimming behavior in estuarine and coastal crab populations. J Exp Mar Bio Ecol 449:45-50. doi: 10.1016/j.jembe.2013.08.013

Minchinton T, Scheibling R (1991) The Influence of Larval Supply and Settlement on the Population Structure of Barnacles. Ecology 72:1867-1879.

Moran A, Emlet R (2001) Offspring Size and Performance in Variable Environments: Field Studies on a Marine Snail. Ecology 82:1597-1612. doi: 10.2307/2679803

Moser G, Sigaud-Kutner T, Cattena C, et al (2004) Algal growth potential as an indicator of eutrophication degree in coastal areas under sewage disposal influence. Aquat Ecosyst Health Manag 7:115-126. doi: 10.1080/14634980490281443

Navarrete S, Wieters E, Broitman B, Castilla J (2005) Scales of benthic-pelagic coupling and the intensity of species interactions: from recruitment limitation to top-down control. Proc Natl Acad Sci U S A 102:18046-18051. doi: 10.1073/pnas.0509119102

Navarro J, Thompson R (1996) Physiological energetics of the horse mussel Modiolus modiolus in a cold ocean environment. Mar Ecol Prog Ser 138:135-148. doi: 10.3354/meps 138135

Newell R (1970) Biology of intertidal animals.

O'Riordan R, Myers A, Cross T (1995) The reproductive cycles of Chthamalus stellatus (Poli) and C. montagui Southward in south-western Ireland. J Exp Mar Bio Ecol 190:17-38. doi: 10.1016/0022-0981(95)00029-Q

O'Riordan R, Power A, Myers A (2010) Factors, at different scales, affecting the distribution of species of the genus Chthamalus Ranzani (Cirripedia, Balanomorpha, Chthamaloidea). J Exp Mar Bio Ecol 392:46-64. doi: 10.1016/j.jembe.2010.04.010

Olson R, Olson M (1989) Food Limitation of Planktotrophic Marine Invertebrate Larvae: Does it Control Recruitment Success? Annu. Rev. Ecol. Syst.

Orton J (1920) Sea-Temperature, Breeding and Distribution in Marine Animals. J Mar Biol Assoc UK (New Ser 12:339-366. doi: 10.1017/S0025315400000102 
Page H (1984) Local variation in reproductive patterns of two species of intertidal barnacles, Pollicipes polymerus Sowerby and Chthamalus fissus Darwin. J Exp Mar Bio Ecol 74:259-272.

Palmer A, Strathmann R (1981) Scale of dispersal in varying environments and its implications for life histories of marine invertebrates. Oecologia 48:308-318.

Patel B, Crisp D (1960) Rates of development of the embryos of several species of barnacles. Physiol Zool 33:104-119.

Pechenik J (1990) Delayed metamorphosis by larvae of benthic marine invertebrates : Does it occur? Is there a price to pay? Ophelia 32:63-94.

Pechenik J (2006) Larval experience and latent effects--metamorphosis is not a new beginning. Integr Comp Biol 46:323-333. doi: 10.1093/icb/icj028

Pechenik J, Estrella M, Hammer K (1996) Food limitation stimulates metamorphosis of competent larvae and alters postmetamorphic growth rate in the marine prosobranch gastropod Crepidula fornicata. Mar Biol 127:267-275. doi: 10.1007/BF00942112

Pechenik J, Gleason T, Daniels D, Champlin D (2001) Influence of larval exposure to salinity and cadmium stress on juvenile performance of two marine invertebrates (Capitella sp. I and Crepidula fornicata). J Exp Mar Bio Ecol 264:101-114. doi: 10.1016/S0022-0981(01)00313-6

Pechenik J, Jarrett J, Rooney J (2002) Relationships between larval nutritional experience, larval growth rates, juvenile growth rates, and juvenile feeding rates in the prosobranch gastropod Crepidula fornicata. J Exp Mar Bio Ecol 280:63-78. doi: 10.1016/S0022-0981(02)00367-2

Pechenik J, Tyrell A (2015) Larval diet alters larval growth rates and post-metamorphic performance in the marine gastropod Crepidula fornicata. Mar Biol. doi: 10.1007/s00227-015-2696-7

Pechenik J, Wendt D, Jarrett J (1998) Metamorphosis Is Not a New Beginning Larval experience influences juvenile performance. Bioscience 48:901-910.

Pepin P, Myers R (1991) Significance of Egg and Larval Size to Recruitment Variability of Temperate Marine Fish. Can J Fish Aquat Sci 48:1820-1828. doi: 10.1139/f91-215

Persson L, Bengtsson J, Menge B, Power M (1995) Food Webs: Integration of Patterns \& Dynamics.

Pfaff M, Branch G, Wieters E, et al (2011) Upwelling intensity and wave exposure determine recruitment of intertidal mussels and barnacles in the southern Benguela upwelling region. Mar Ecol Prog Ser 425:141-152. doi: 10.3354/meps09003

Pfeiffer-Hoyt A, Mcmanus M (2005) Modeling the effects of environmental variability on Balanus glandula larval development. J Plankton Res 27:1211-1228. doi: 10.1093/plankt/fbi089

Phillips N (2005) Growth of filter-feeding benthic invertebrates from a region with variable upwelling intensity. Mar Ecol Prog Ser 295:79-89. doi: 10.3354/meps295079

Phillips N (2004) Variable Timing of Larval Food Has Consequences for Early Juvenile Performance in a Marine Mussel. Ecology 85:2341-2346. doi: 10.1890/03-3097

Phillips N (2006) Natural variability in size and condition at settlement of 3 species of marine invertebrates. Integr Comp Biol 46:598-604. doi: 10.1093/icb/ic1008

Phillips N (2002) Effects of nutrition-mediated larval condition on juvenile performance in a marine mussel. Ecology 83:2562-2574.

Pierce D (2015) ncdf4: Interface to Unidata netCDF (version 4 or earlier) format data files. Rpackage version 1.15. 
Pilsbry H (1916) The sessile barnacles (cirripedia) contained in the collections of the U.S. National museum; including a monograph oh the american species.

Pineda J (1994) Spatial and temporal patterns in barnacle settlement rate along a Southern California rocky shore. Mar Ecol Prog Ser 107:125-138. doi: 10.3354/meps 107125

Pineda J, Porri F, Starczak V, Blythe J (2010) Causes of decoupling between larval supply and settlement and consequences for understanding recruitment and population connectivity. J Exp Mar Bio Ecol 392:9-21. doi: 10.1016/j.jembe.2010.04.008

Pineda J, Reyns N, Starczak V (2009) Complexity and simplification in understanding recruitment in benthic populations. Popul Ecol 51:17-32. doi: 10.1007/s10144008-0118-0

Pitombo F, Burton R (2007) Systematics and Biogeography of Tropical Eastern Pacific Chthamalus with Descriptions of Two New Species (Cirripedia, Thoracica). Zootaxa 1-30.

Pitt N, Poloczanska E, Hobday A (2010) Climate-driven range changes in Tasmanian intertidal fauna. Mar Freshw Res 61:963-970. doi: 10.1071/MF09225

Poorbagher H, Lamare M, Barker M (2010) The relative importance of parental nutrition and population versus larval diet on development and phenotypic plasticity of Sclerasterias mollis larvae. J Mar Biol Assoc United Kingdom 90:527-536. doi: 10.1017/S0025315409990907

Raimondi P (1990) Patterns, mechanisms, consequences of variability in settlement and recruitment of an intertidal barnacle. Ecol Monogr 60:283-309.

Reznick D, Callahan H, Llauredo R (1996) Maternal Effects on Offspring Quality in Poeciliid Fishes. Am Zool 36:147-156.

Reznick D, Yang A (1993) The influence of fluctuating resources on life history patterns of allocation and plasticity in female guppies. Ecology 74:2011-2019.

Roughgarden J, Gaines S, Possingham H (1988) Recruitment dynamics in complex life cycles. Science (80- ) 241:1460 - 1466.

Sanford E, Bermudez D, Bertness M, Gaines S (1994) Flow, food supply and acorn barnacle population dynamics. Mar Ecol Prog Ser 104:49-62.

Sanford E, Menge B (2001) Spatial and temporal variation in barnacle growth in a coastal upwelling system. Mar Ecol Prog Ser 209:143-157.

Scheltema R, Williams I (1982) Significance of temperature to larval survivial and lenght of development in Balanus eburneus (Crustacea: Cirripedia). Mar Ecol Prog Ser 9:43-49.

Schmiegelow J, Gianesella S, Simonetti C, et al (2008) Primary producers in Santos estuarine system. Perspectives on Integrated Coastal Zone Management in South America. pp 161-174

Schneider A, Rasband W, Eliceiri K (2012) NIH Image to Image J: 25 years of image analysis. Nat Methods 9:671-675.

Searcy S, Sponaugle S (2000) Variable larval growth in a coral reef fish. Mar Ecol Ser 206:213-226. doi: 10.3354/meps206213

Shahdadi A, Sari A (2010) Chthamalid barnacles (Cirripedia: Thoracica) of the Persian Gulf and Gulf of Oman, Iran. J Mar Biol Assoc United Kingdom 91:745-753. doi: $10.1017 / \mathrm{S} 0025315410001803$

Shima J, Findlay A (2002) Pelagic larval growth rate impacts benthic settlement and survival of a temperate reef fish. Mar Ecol Prog Ser 235:303-309. doi: $10.3354 /$ meps 235303

Shima J, Swearer S (2009) Larval quality is shaped by matrix effects: implications for 
connectivity in a marine metapopulation. Ecology 90:1255-1267.

Silva Jr C, Kampel M, Araujo C, Stech J (1996) Observação da penetração do ramo costeiro da corrente das malvinas na costa sul-sudeste do Brasil a patir de imagens AVHRR. Anais VIII Simpósio Brasileiro de Sensoriamento Remoto, Slavador, Brasil. pp 787-793

Sinervo B (1990) The evolution of maternal investment in lizards: an experimental and comparative analysis of egg size and its effects on offspring performance. Evolution (N Y) 44:279-294.

Skinner L, Coutinho R (2010) Preliminary results on settlement of the barnacles Tetraclita stalactifera and Chthamalus bisinuatus on a Brazilian tropical rocky shore under upwelling conditions. Invertebr Reprod Dev 41:151-156. doi: 10.1080/07924259.2002.9652746

Southward A, Crisp D (1956) Flutuations in the Distribution and Abundance of Intertidal Barnacles. J Mar Biol Assoc UK 35:211-229.

Southward A, Newman W (2003) A review of some common Indo-Malayan and western Pacific species of Chthamalus barnacles (Crustacea: Cirripedia). J Mar Biol Assoc United Kingdom 83:797-812. doi: 10.1017/S0025315403007835h

Starr M, Himmelman J, Therriault J (1991) Coupling of nauplii release in barnacles with phytoplankton blooms: A parallel strategy to that of spawning in urchins and mussels. J Plankton Res 13:561-571. doi: 10.1093/plankt/13.3.561

Stephens P, Sutherland W, Freekleton R (1999) What is the Allee effect? Oikos 87:185190.

Stramski D, Reynolds R, Babin M, et al (2007) Relationships between the surface concentration of particulate organic carbon and optical properties in the eastern South Pacific and eastern Atlantic Oceans. Biogeosciences Discuss 4:3453-3530. doi: 10.5194/bgd-4-3453-2007

Strathmann R (1985) Feeding and Nonfeeding Larval Development and Life-History Evolution in Marine Invertebrates. Annu Rev Ecol Syst 16:339-361. doi: 10.1146/annurev.ecolsys.16.1.339

Sutherland JP (1990) Recruitment regulates demographic variation in a tropical intertidal barnacle. Ecology 71:955-972. doi: 10.2307/1937365

Takanohashi R, Castro N, Pollery R, et al (2014) The influence of surface low-salinity waters and cold subsurface water masses on picoplankton and ultraplankton distribution in the continental shelf of Rio de Janeiro, SE Brazil. Cont Shelf Res 120:82-95. doi: 10.1016/j.csr.2016.02.017

Tanaka M, Duarte L (1998) Recruitment variation of the barnacle Chthamalus bisinuatus Pilsbry 1916 in an exposed rocky shore in southeast Brazil. Bull Mar Sci 62:285-292.

Thiyagarajan V, Harder T, Qian P (2002) Relationship between cyprid energy reserves and metamorphosis in the barnacle Balanus amphitrite Darwin (Cirripedia; Thoracica). J Exp Mar Bio Ecol 280:79-93. doi: 10.1016/S0022-0981(02)00415-X

Thiyagarajan V, Harder T, Qian P (2003) Effects of TAG/DNA ratio and age of cyprids on post-metamorphic growth and survival in the barnacle Balanus amphitrite. $\mathrm{J}$ Mar Biol Assoc UK 83:83-88.

Thompson P, Harrison P (1992) Effects of monospecific algal diets of varying biochemical composition on the growth and survival of Pacific oyster (Crassostrea gigas) larvae. Mar Biol 113:645-654. doi: 10.1007/BF00349708

Thorson G (1950) Reproductive and larval ecology of marine bottom invertebrates. Biol Rev 25:1-45. doi: 10.1111/j.1469-185X.1950.tb00585.x

Todd C (1998) Larval supply and recruitment of benthic invertebrates : do larvae always 
disperse as much as we believe ? Hydrobiologia 375/376:1-21.

Toonen R, Pawlik J (2001) Settlement of the gregarious tube worm Hydroides dianthus (Polychaeta: Serpulidae). II. Testing the desperate larva hypothesis. Mar Ecol Prog Ser 224:115-131. doi: 10.3354/meps224115

Torres G, Giménez L, Pettersen A, et al (2016) Persistent and context-dependent effects of the larval feeding environment on post-metamorphic performance through the adult stage. Mar Ecol Prog Ser 545:147-160. doi: 10.3354/meps11586

Toupoint N, Gilmore-Solomon L, Bourque F, et al (2012) Match/mismatch between the Mytilus edulis larval supply and seston quality: effect on recruitment. Ecology 93:1922-1934. doi: 10.1890/11-1292.1

Underwood A (1997) Experiments in Ecology - Their logical design and interpretation using analysis of variance.

Vance R (1973) On reproductive strategies in marine benthic invertebrates. Am Nat 107:339-352.

Voss R, Clemmesen C, Baumann H, Hinrichsen H (2006) Baltic sprat larvae: Coupling food availability, larval condition and survival. Mar Ecol Prog Ser 308:243-254. doi: $10.3354 /$ meps 308243

Wendt D, Johnson C (2006) Using latent effects to determine the ecological importance of dissolved organic matter to marine invertebrates. Integr Comp Biol 46:634-642. doi: 10.1093/icb/ic1025

Wethey D (1983) Geographic limits and local zonation: the barnacles Semibalanus ( Balanus) and Chthamalus in New England. Biol Bull 165:330-341. doi: 10.1094/PDIS.1999.83.11.1073B

Wethey D (1984) Effects of crowding on fecundity in barnacles: Semibalanus (Balanus) balanoides, Balanus glandula, and Chthamalus dalli. Can J Zool 62:1788-1795. doi: $10.1139 / \mathrm{z} 84-261$

Wilbur H (1980) Complex Life Cycles. Annu Rev Ecol Syst 11:67-93. doi: 10.1146/annurev.es.11.110180.000435

Wisley B (1960) Experiments on Rearing the Barnacle Elminius modestus Darwin to the Settling Stage in the Laboratory. Mar Freshw Res 11:42. doi: 10.1071/MF9600042

Wotton R (1988) Dissolved organic material and trophic dynamics: What is the food of filtering collectors in aquatic ecosystems? Bioscience 38:172-178.

Wu R (1980) Effects of crowding on the energetics of the barnacle Balanus glandula Darwin. Can J Zool 58:559-566. doi: 10.1139/z80-078

Yan Y, Chan B, Williams G (2006) Reproductive development of the barnacle Chthamalus malayensis in Hong Kong: implications for the life-history patterns of barnacles on seasonal, tropical shores. Mar Biol 148:875-887. doi: $10.1007 / \mathrm{s} 00227-005-0117-\mathrm{z}$

Yan Y, Miao S (2004) The Effect of Temperature on the Reproductive Cycle of the Tropical Barnacle, Chthamalus malayensis Pilsbry ( Cirripedia ). Crustaceana 77:205-212.

Young P (1993) The Verrucomorpha Chthamaloidea from the Brazilian coast (Crustacea: Cirripedia). Rev Bras Biol 53:255-267.

Zabin C, Altieri A (2007) A Hawaiian limpet facilitates recruitment of a competitively dominant invasive barnacle. Mar Ecol Prog Ser 337:175-185. doi: $10.3354 /$ meps337175 


\section{CHAPTER 02 - Seasonal patterns of larval production and quality in subtropical barnacle populations along a coastal trophic gradient}

\section{Introduction}

Barnacles are present in a vast geographical range, inhabiting intertidal zones of rocky shores from subtropical to temperate regions, often in dense aggregations (Southward and Newman 2003; Pitombo and Burton 2007). These sessile organisms are hermaphrodite, reproducing through crossed internal fertilization, although self-fertilization can be observed in some species (Barnes and Crisp 1956; Anderson 1994). Its larval development involves 6 naupliar instars, which feed and swim in the water column, and a final cyprid instar, which do not feed and is responsible for the settlement on a substrate and metamorphosis to the juvenile phase. Barnacles from warm-water regions can produce several broods per year, having often a reproductive peak during the warmer months of the year and reduced egg production during the colder months (Barnes 1989; Anderson 1994). Environmental variables as temperature, photoperiod, salinity, wave exposure and food supply are known factors acting directly on the reproductive cycle of these organisms (Patel and Crisp 1960; Barnes and Barnes 1965; Hines 1978; Page 1984; Burrows et al. 1992; O’Riordan et al. 1995).

Intertidal rocky shores and adjacent coastal oceans are very dynamic habitats, and environmental conditions for both adult barnacles and their pelagic larvae often range from optimal to life-threatening in a few days (Garrabou et al. 2001; Navarrete et al. 2005; Harley 2008; Garrabou et al. 2009). The stability and persistence of barnacle populations may depend on reproductive tactics based on 
responses to environmental conditions, signaling for instance the trophic status (Starr et al. 1991; Leslie et al. 2005b) of the water column and the odds for optimal physiological functioning and benthic survival (Torres et al. 2016). When facing temporally variable conditions, breeding individuals might change their reproductive strategy in order to optimize their fitness, i.e. to maximize future reproductive output, which might directly influence fecundity (Beckerman et al. 2006) and larval quality (Sinervo 1990; Marshall and Keough 2004).

Both reproductive aspects, fecundity and larval quality, depend on the amount of energetic resources the maternal population can provide to its progeny. This capacity, in turn, is limited by environmental resources available to mothers, their perception of changing environmental conditions and capacity to obtain, assimilate and transfer energetic resources to either their own or their offspring survival (Bernardo 1996; Marshall and Uller 2007). There are different strategies that maternal populations may follow as to maximize their fitness. In uncertain environments, mothers might invest less energy in their offspring and maintain their own fitness, a selfish strategy, or alternatively produce larvae with variable quality, and thus ensure that at least some of their offspring will have high chances of survival; a "bet-hedging" strategy (Bertram and Strathmann 1998; Marshall et al. 2008). Also, maternal populations might be able to predict the larval environment conditions through biotic and abiotic cues and invest proportional energy for their descendants (Fox et al. 1997; Allen et al. 2008). Considering that nearshore oceanographic conditions, and thus food supply, are often very heterogeneous, sessile organisms, like barnacles, would greatly benefit from energetic storage for reproduction, growth and other metabolic functions in moments of scarcity. 
Much work on life-history tactics and reproductive strategies has been carried out on temperate barnacles, which typically follow very regular breeding cycles, but little is known on the reproductive ecology of tropical species, such as Chthamalus bisinuatus (Pilsbry, 1916). In tropical and subtropical regions, environmental variables which usually play a determinant role on the timing of reproductive activity, such as photoperiod and temperature (Mcclintock and Stephen 1990; Desai et al. 2006; Yan et al. 2006) might be overridden by other more stochastic variables. Seasonal range of daylight hours or average temperature is much narrower towards the tropics and other variables may become more important, such as rainfall or salinity changes (Barnes and Barnes 1968; Barnes 1989). In tropical habitats, temperature may restrain physiological activity and oligotrophic conditions may impose severe feeding limitations during the warmer season. The barnacle $C$. bisinuatus may undergo seasonal reproduction with maximum breeding effort during the warmer season, from early summer to early autumn (Barbosa et al. 2016), but more unpredictable timing may emerge, possibly owing to resource limitation, with larval release following pulses of phytoplankton primary production, or exceedingly high thermal stress (Kasten and Flores 2013). Because barnacles are filter-feeding organisms, the maternal environment, during immersion periods, may signal the trophic status for both adults and larvae, as their food resources (i.e. phytoplankton and particulate organic matter) may largely overlap. However, C. bisinuatus is presently distributed over a wide geographical distribution, from northeastern Brazilian to Uruguay (Dando and Southward 1980; Young 1993), making it difficult to predict the prevailing environmental conditions that shaped the selection of reproductive traits in this species. The southeastern coast of Brazil, where this study was 
undertaken, is located in a broad transition zone (Ciotti et al. 2010) between the more tropical conditions found at the northern coast of Rio de Janeiro up north, and the warm temperate environment found at Rio Grande do Sul to Uruguay. Along the coastline of São Paulo State, there are also clear-cut differences of the nearshore trophic status. In the Santos region, coastal waters present high concentrations of nutrients and organic dissolved matter, a consequence of the heavily polluted estuarine complex owing to effluents from the industrial pole of Cubatão and dense urban clusters, which are considered as eutrophic (Braga et al. 2000; Aguiar and Braga 2007). In contrast, the coastal ocean along the northern coast of São Paulo State, including the cities of São Sebastião, Caraguatatuba and Ubatuba, is characterized by low primary productivity and dissolved organic matter concentration, ranging from meso to oligotrophic (Gaeta et al. 1999; Gianesella et al. 1999). Therefore, different reproductive strategies could be hypothesized for C. bisinuatus populations along the geographical gradient between these two extremes.

In this study, we assessed the spatial structure and respective seasonal consistency, of the pelagic trophic state adjacent to different rocky shores within the spatial gradient describe above, and sampled a subset of these localities for a concurrent examination of key barnacle reproductive parameters. We were interested to (i) verify whether proxies of pelagic food supply are spatially consistent and assess their seasonal variation, (ii) compare the relevance of seasonal and ecologically relevant spatial scales in the determination of barnacle reproductive patterns, and (iii) test whether reproduction responses are aligned to the spatial and temporal variation of trophic resources or, alternatively, parental 
populations manipulate embryonic provisioning potentially dampening environmental effects.

\section{Methodology}

Remote sensing analyses, field sampling and laboratory procedures aimed the assessment of the coastal trophic conditions and the quantification of reproductive output for a set of locations during two different periods; the warm and main breeding season (summer-early autumn 2013) and the non-breeding cool season (winter 2014).

Characterization of the pelagic trophic status at sampling sites

To investigate spatial-temporal variations of food availability for adult populations along the possible trophic gradient specified above, 8 different sites where chthamalid barnacles were known to be common, and spanning a coastline ca. $150 \mathrm{~km}$ encompassing a potential gradient of nearshore trophic enrichment, were chosen for analysis. The sites were: Éden (2359'15"S; 46¹1'06" W), São

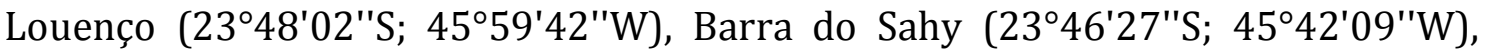

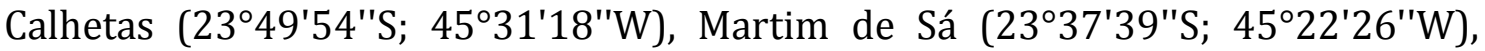

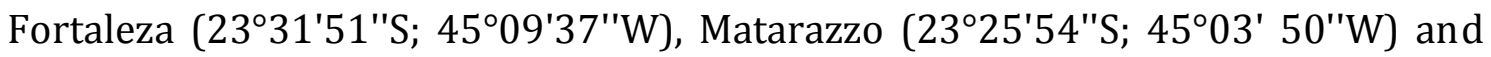
Cambury (2322'14"S; 44²4'16"W; Fig. 1). 


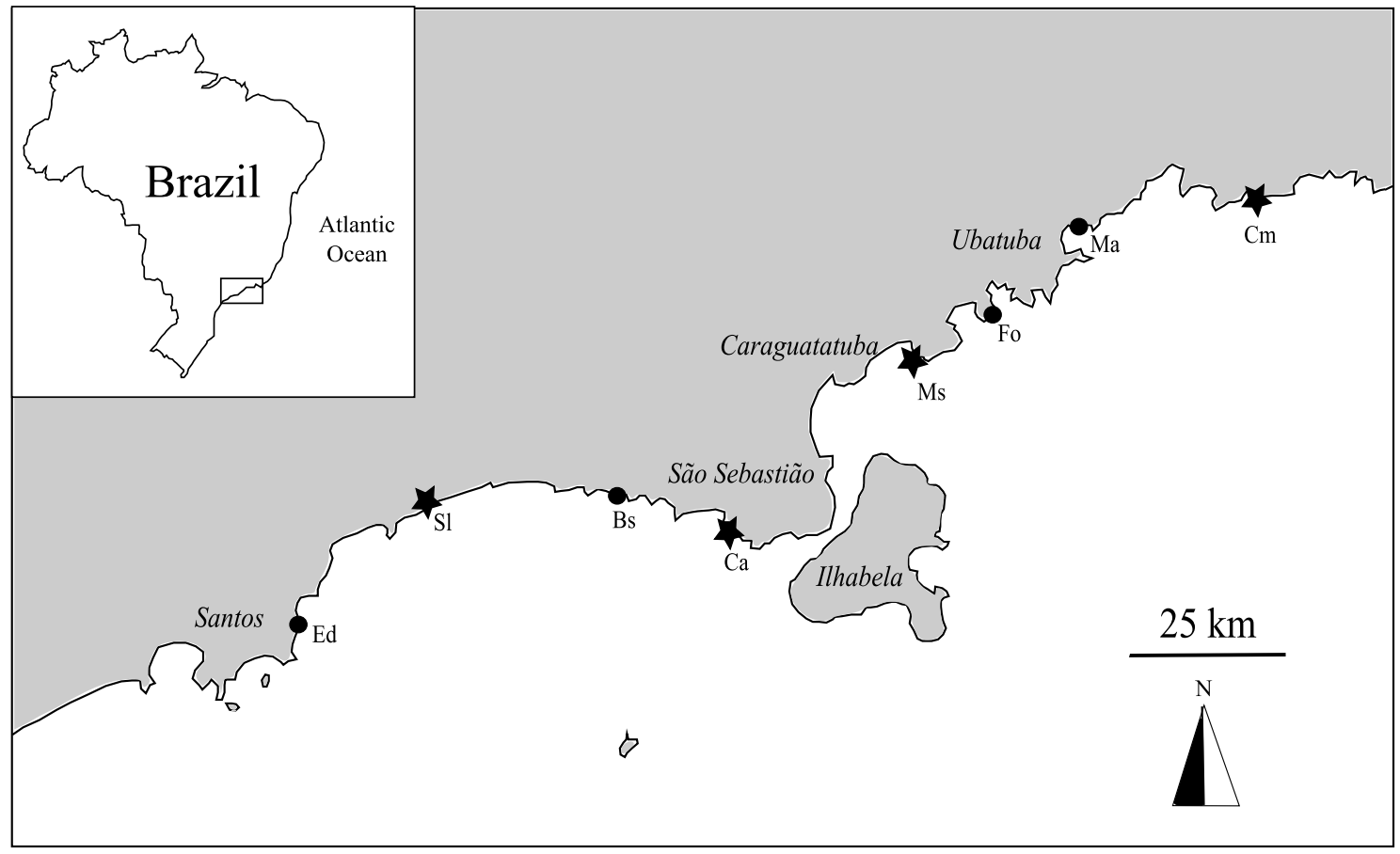

Figure 1. Sampling sites selected for this study. Ed: Éden; Sl: São Lourenço; Bs: Barra do Sahy; Ca: Calhetas; Ms: Martim de Sá; Fo: Fortalezza; Ma: Matarazzo; Cm: Cambury. The trophic status of the water column was assessed for all sites. Star symbols indicate sites where barnacle populations were sampled.

Chlorophyll- $a$ (CHL) and particulate organic carbon (POC) concentrations were used as proxy of food availability. For that, remote sensing data for surface chlorophyll- $a$ (Hu et al. 2012) and particulate organic carbon (Stramski et al. 2007) concentrations were acquired for the MODIS-Aqua sensor (NASA 2014). While POC is a proxy for the plankton assemblage carbon content, CHL is a light-harvesting pigment present only in primary producers. Level-3 mapped images of $4 \mathrm{~km}$ resolution aggregated by seasons for the summer 2013 and winter 2014, were processed with the R packages ncdf4 (Pierce 2015), raster (Hijmans 2015) and rgdal (Bivand et al. 2015) for data extraction, using a buffer of $9 \mathrm{~km}$ around each site. The replicates for seasonal values in the analysis were an integration of the available daily measurements performed by satellites. Weekly averages for two 
consecutive months over the breeding (February and March 2013) and the nonbreeding (July and August 2014) were used for analyses. During these periods there were no missing data due to clouding or any other atmospheric conditions precluding the acquisition of satellite images.

\section{Field sampling and laboratory routine}

Among the eight sampling sites examined above, we selected four of them (São Lourenço, Calhetas, Martim de Sá and Cambury; Fig. 1) for field barnacle sampling in an attempt to cover the expected gradient of CHL and POC (see results). Two replicate separated approximately by $50 \mathrm{~m}$ of $\sim 15$ rock chips containing Chthamalus bisinuatus adults, at each of three dates within the breeding (January 25th-30th, February 26th - March 6th and March 14th - 28th in 2013), and non-breeding seasons (July 4th-21st, August 31st- September 11th and September 14th- October 6th in 2014), were collected at these four sites. Rock chips were photographed (Sony DSC W380) for the estimation of barnacle cover area using the ImageJ software (Schneider et al. 2012), and then randomly allocated in aquaria in laboratory rooms held at $25^{\circ} \mathrm{C}$. In order to stimulate larval release, experimental populations were first kept dry for $24 \mathrm{~h}$ and then permanently submerged in pre-filtered $(25 \mu \mathrm{m})$ seawater for another $24 \mathrm{~h}$. This procedure was repeated until a spawning event was observed. Fecundity was calculated by dividing the total number of nauplii released by the adult cover area (nauplii.cm ${ }^{-2}$ ). Larval quality was inferred as the time nauplli endured without exogenous food supply. For that, we randomly separated 300 recently spawned nauplii from each experimental population (= rock chip) and maintained them separately in individual $2 \mathrm{ml}$ wells of cell culture plates (Corning ${ }^{\mathrm{TM}}$ Costar $^{\mathrm{TM}}$ ) filled 
with pre-filtered seawater $(25 \mu \mathrm{m})$. Wells were inspected daily to check for new deaths.

\section{Statistical analyses}

Two-way analyses of variance, in which 'site' and 'season' were considered fixed factors, were run to test for spatial patterns, and their consistency between the breeding and non-breeding season, for both the trophic status of the water column (CHL and POC) and the reproductive parameters of barnacle populations (survival of food-deprived larvae, and fecundity). The SNK procedure was undertaken for pair-wise comparisons when applicable. In all cases analyses were balanced. POC and CHL were ln-transformed to meet homoscedasticity. No transformations corrected heteroscedasticity for the data of nauplii survival. We ran the original model anyway for this variable, using raw data, since the interpretation of results based on a balanced design and large sample size $(n=300$ in this particular case) is not affected by variance heterogeneity (Underwood 1997).

Pearson correlations were also tested for larval quality (survival) and (i) pelagic conditions (CHL and POC), for a first appraisal on how the parental population allocate resources to their offspring across a larger spatial scale; and (ii) fecundity, as an initial test of a possible trade-off between offspring number and their quality. 


\section{Results}

Sampling sites and pelagic trophic status

After extracting data from satelite images for the eight sites, it was possible to observe seasonal and spatial differences (Table 1) for proxies of food availability, CHL and POC, adjacent to shorelines

Table 1. Summary results of the ANOVA model used to compare chlorophyll- $a$ (CHL) and particulate organic carbon content (POC) in the water column adjacent to different sites, and during different seasons (breeding vs. non-breeding). Statistical significance is highlighted in bold. SV: source of variation; df: degrees of freedom; MS: mean squares; $C$ : Cochran's statistic.

\begin{tabular}{|c|c|c|c|c|c|c|c|c|}
\hline & \multicolumn{4}{|c|}{ CHL } & \multicolumn{4}{|c|}{ POC } \\
\hline & $\mathrm{df}$ & MS & $F$ & $p$ & $\mathrm{df}$ & MS & $F$ & $p$ \\
\hline Site & 7 & 1.23 & 12.2 & $<0.001$ & 7 & 0.37 & 4.71 & $<0.001$ \\
\hline Season & 1 & 13.21 & 130.62 & $<0.001$ & 1 & 19.56 & 248.77 & $<0.001$ \\
\hline Site*Season & 7 & 0.13 & 1.25 & 0.285 & 7 & 0.05 & 0.59 & 0.761 \\
\hline Error & 90 & 0.1 & & & 80 & 0.08 & & \\
\hline $\operatorname{Ln}(\mathrm{X})$ tra & nsfo & med; $C$ & $=0.1745$ & (ns) & & $\begin{array}{r}\text { (X) trar } \\
0.17\end{array}$ & $\begin{array}{l}\text { isformec } \\
47 \text { (ns) }\end{array}$ & $\mathrm{d} ; C=$ \\
\hline
\end{tabular}

Two main trends could be identified in these analyses. First, concentrations of CHL and POC were much higher during the non-breeding season (winter), compared to the breeding season (late summer - autumn). Second, the gradient observed when sites are arranged from the southwestern to the northeastern end of the sampled shoreline (Fig. 2) follows expectations, with average CHL and POC tending to decrease in this direction. 

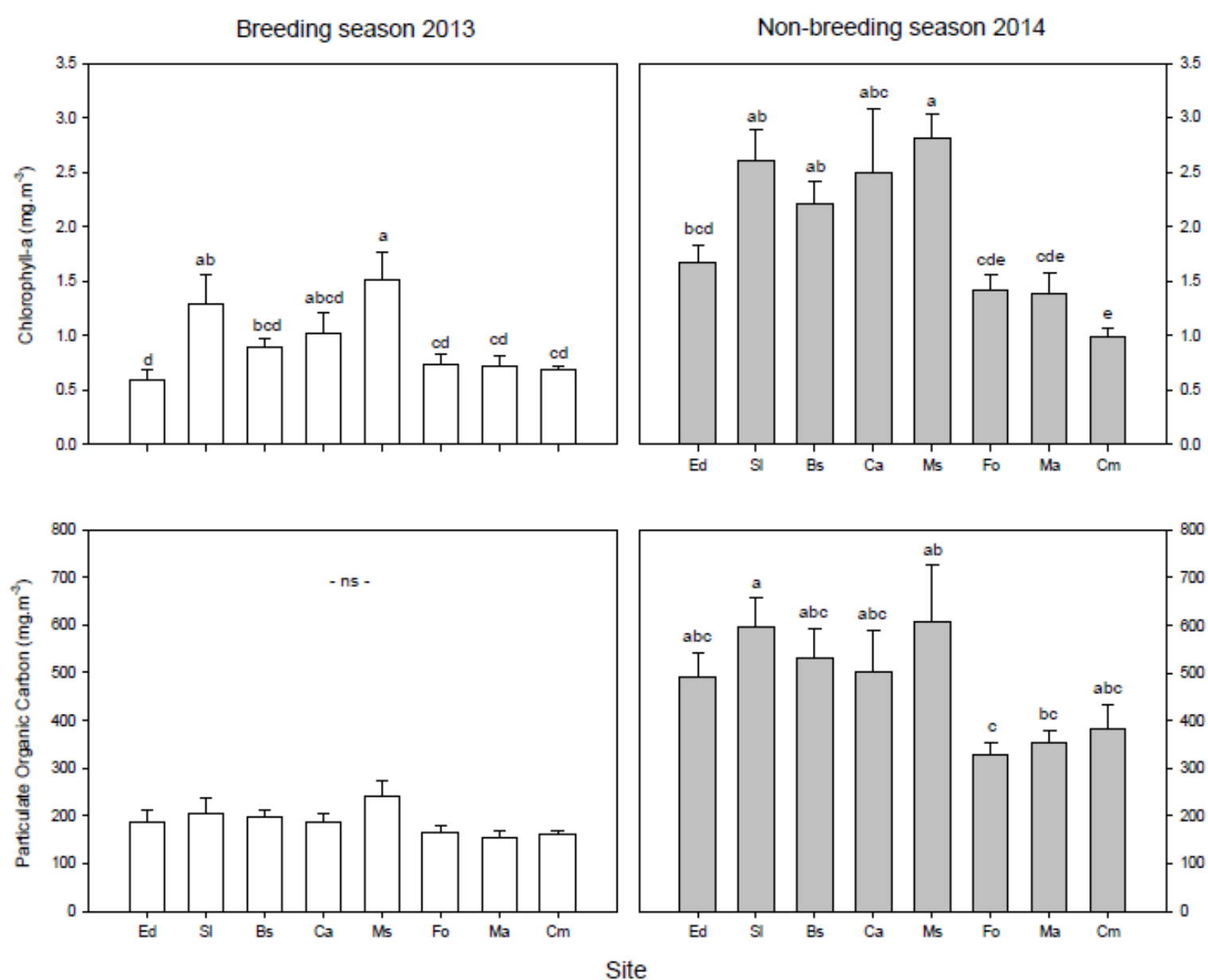

Figure 2. Spatial contrasts of chlorophyll- $a$ and particulate organic carbon concentrations along the São Paulo State coast, during the barnacle breeding and non-breeding seasons. Vertical bars represent standard errors. Within-seasons, estimates at sites sharing no letters are significantly different $(p<0.05)$. ns $=$ not significant. Site abbreviations as in Fig. 1.

Also, site ranks were rather consistent between seasons, as indicated by a non-significant interaction of the term 'site' X 'season' for both parameters (Table 1). This is especially true for CHL in which, despite of a great difference between sampling periods, São Lourenço e Martim de Sá exhibited higher concentrations of CHL compared to the northernmost sites Fortaleza, Matarazzo and Cambury. Differences between seasons were even larger for POC, with sites varying in a very 
narrow range during the main breeding season (between 150 and 250 mg.m ${ }^{-3}$ ), with no apparent spatial structure (Fig. 2). Averages for winter were over the double (c.a. 475 mg.m ${ }^{-3}$ ) and among-site differences become substantial, resembling the pattern found for CHL. For instance, São Lourenço differed from Matarazzo and Cambury, and Martim de Sá differed from Fortaleza. Therefore, oceanographic processes setting contrasts on CHL and POC at the spatial scale examined are likely the same or very similar.

\section{Reproductive variables: larval quality and larval production}

For both sampling periods, food-deprived larvae originated from different maternal populations presented different survival times (Table 2, Fig. 3).

Table 2. Summary results of the ANOVA model used to compare fecundity (as larval release) and larval survival (in days) in the water column adjacent to different sites, and during different seasons (breeding vs. non-breeding). Statistical significance is highlighted in bold. SV: source of variation; df: degrees of freedom; MS: mean squares; C: Cochran's statistic.

\begin{tabular}{|c|c|c|c|c|c|c|c|c|}
\hline & \multicolumn{4}{|c|}{ Fecundity } & \multicolumn{4}{|c|}{ Larval survival } \\
\hline & df & MS & $F$ & $p$ & $\mathrm{df}$ & MS & $F$ & $p$ \\
\hline Site & 3 & 337 & 1.59 & 0.217 & 3 & 243.8 & 37.01 & $<0.001$ \\
\hline Season & 1 & 1422 & 6.73 & 0.016 & 1 & 1832.3 & 279.26 & $<0.001$ \\
\hline Site*Season & 3 & 191 & 0.9 & 0.455 & 3 & 125.1 & 19.07 & $<0.001$ \\
\hline Error & 24 & 211 & & & 392 & 6.6 & & \\
\hline \multicolumn{5}{|c|}{ Raw data; $C=0.3717$ (ns) } & \multicolumn{4}{|c|}{$\begin{array}{c}\text { Raw data; } C=0.2471(p< \\
0.01)\end{array}$} \\
\hline
\end{tabular}




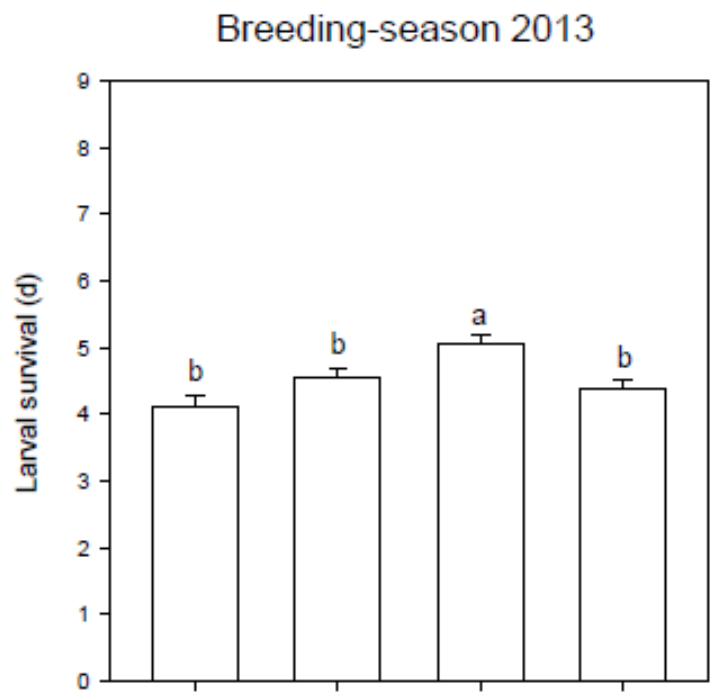

Non-breeding season 2014
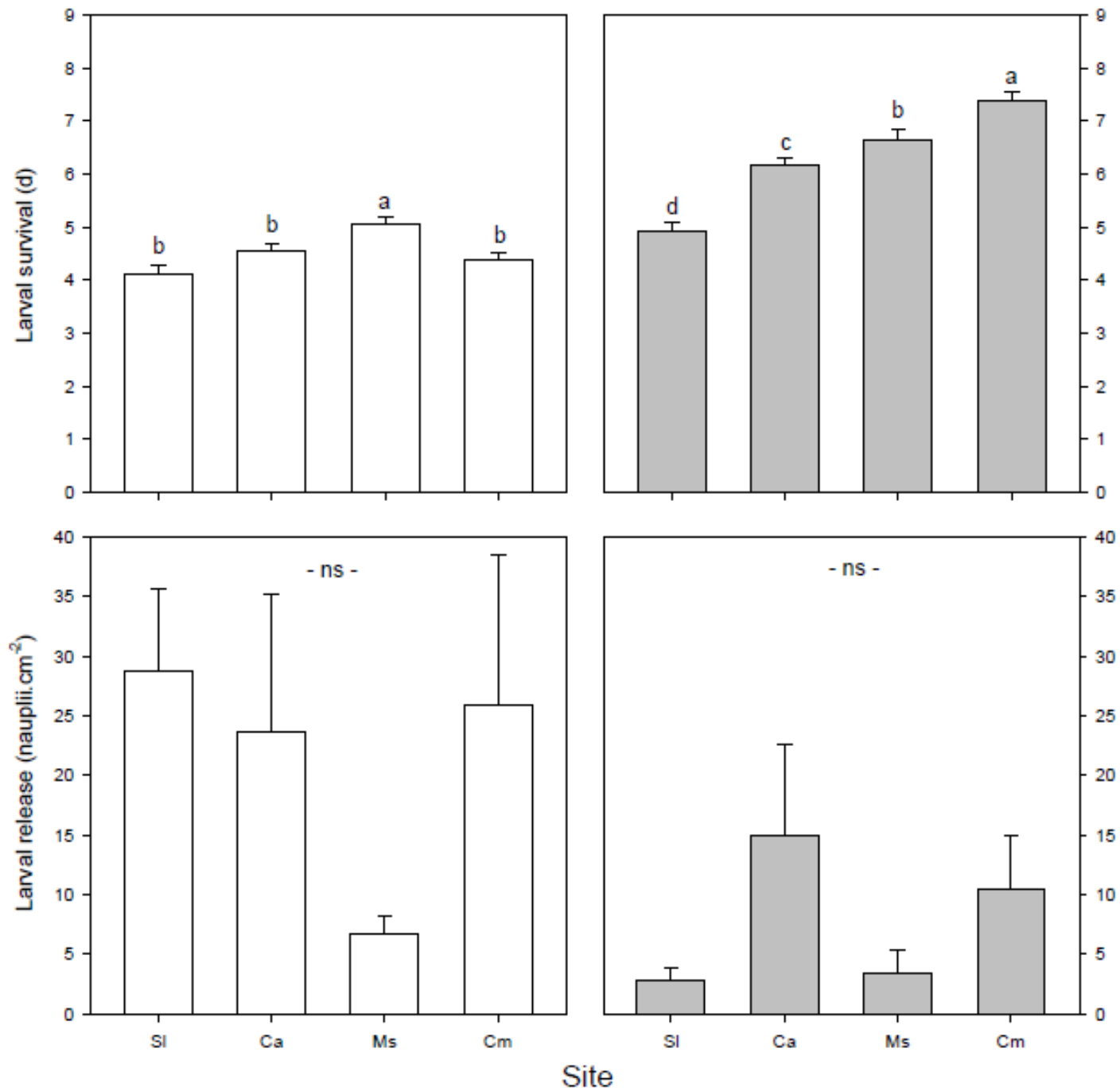

Figure 3. Spatial contrasts of barnacle reproductive parameters, larval quality (as survival, in days) and larval production (as larval release per unit cover) among sampled sites, during the breeding and non-breeding seasons. Vertical bars represent standard errors. Within-seasons, estimates at sites sharing no letters are significantly different $(p<$ 0.05). ns = not significant. Site abbreviations as in Fig. 1.

Average larval survival was lower during the breeding season (4.53 d) compared to the non-breeding season (6.28 d; Table 2), and, closely resembling the environmental variables CHL and POC, spatial differences were very narrow in the warmer breeding season compared to winter, when a more clear spatial structure was observed. More specifically, during the breeding season, larvae released from 
Martim de Sá populations survived slightly longer than those produced from barnacles of the remaining sites, while site-specific survival was observed during the non-breeding season, with a steady increase from São Lourenço to Cambury populations (Fig, 3).

Fecundity, as the number of larvae spawned per $\mathrm{cm}^{2}$ of living barnacle cover, differed significantly between sampling periods (Table 2), with a much higher number of larvae produced during the main breeding season (21.1 nauplii. $\left.\mathrm{cm}^{-2}\right)$, compared to winter $\left(7.9\right.$ nauplii. $\left.\mathrm{cm}^{-2}\right)$. However, exceedingly high variation of larval output among rock chips taken at each site and at different times within each period precluded the observation of eventual spatial trends. In spite of up to 4 to 5 fold differences of larval production estimates among sites during the breeding and non-breeding seasons, respectively, spatial contrasts were not significant (Table 2, Fig. 3).

Interpretations of temporal differences of larval production are straightforward, since they are aligned to a breeding pattern already documented (Barbosa et al. 2016), and lack of any detected spatial trends leads no justification for further procedures attempting the identification of possible underlying processes. For larval quality, however, we used both spatial and temporal variability to test correlations of nauplii survival and the trophic environment experienced by the paternal populations (CHL and POC), and larval overall production, as this could shed some light on eventual maternal effects. These correlations are showed in figure 4. 

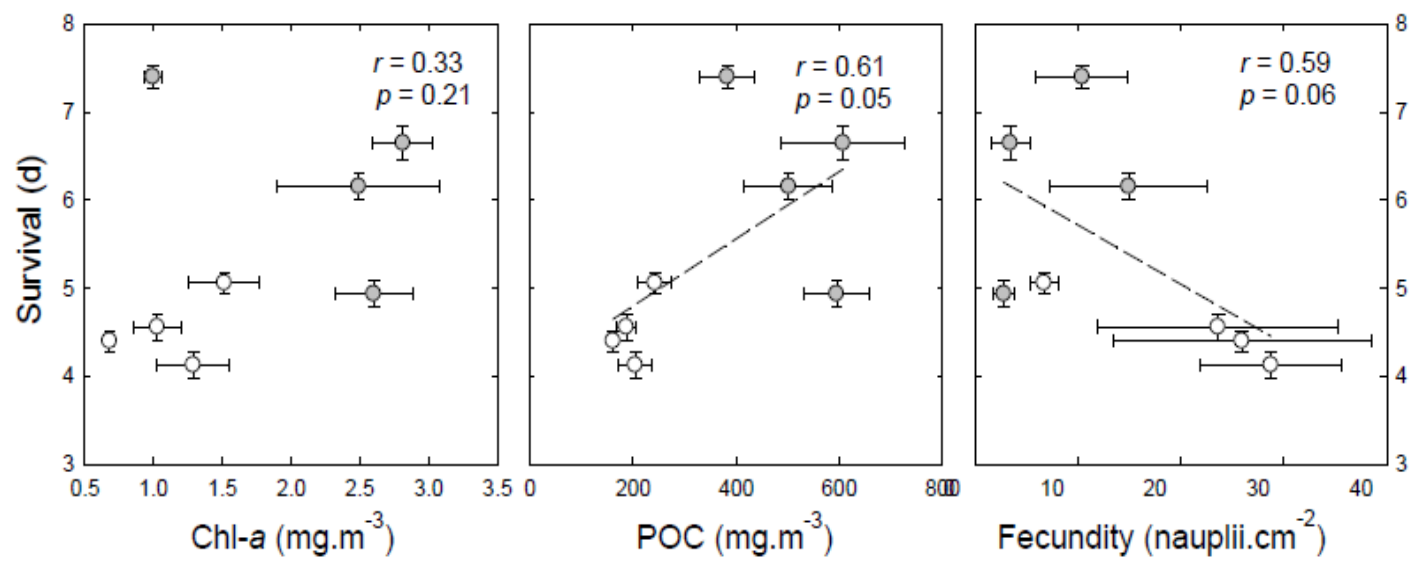

Figure 4. Correlations between larval quality (as survival, in days) and (i) proxies of food supply to parental barnacle populations (chlorophyll- $a$ and particulate organic matter concentrations), and (ii) overall larval production (as fecundity). White and gray symbols stand for observations obtained in summer and winter. Whiskers represent standard errors for both correlated variables in each case.

When accounting for both spatial $(150 \mathrm{~km})$ and temporal (5-7 months) variability, larval survival was positively correlated to POC, suggesting a positive effect through food supply to parental populations (Fig. 4). A similar trend was observed for CHL, but the correlation was not significant. In specific, populations at the oligotrophic site Cambury produced exceptionally high-quality larvae during winter. If this observations is removed from analysis, the correlation coefficient increased to 0.812 and the value decreases to significance $(p=0.01)$. A marginal $p$ value (0.06) indicates a negative correlation between larval quality and larval production (as larvae released per unit area). 


\section{Discussion}

In this study we aimed to detect spatial and temporal patterns of environmental proxies of food availability, and assess whether the trophic state of the coastal ocean correlates with larval production and larval quality in the tropical barnacle Chthamalus bisinuatus. Temporal variation was shown to be more relevant than spatial variation in the determination of both the trophic state of the water column and the barnacle larval parameters examined. Apart from the quantity of larvae produced, which was higher during the warmer season, as predicted, and lacked any spatial structure, proxies of food supply to barnacle parental populations (CHL indicating phytoplankton biomass, and POC indicating organic particulate matter) and larval quality presented much higher values during the winter, out of the main breeding season for this barnacle species, when spatial structures become emerged or intensified. Therefore, resources are scarcer when barnacle reproduction is more intense. Seasonal differences of overall larval release (this study) and gonad production (Barbosa et al. 2016) thus provide independent evidence for a relatively fixed breeding season likely modulated by seasonal changes of air temperature and / or photoperiod (Barnes 1989; Anderson 1994).

Because larval food resources may be scant in warm tropical oligotrophic pelagic systems (Metzler et al. 1997; Longhurst 1998) causing high mortality, and taking into account that poor larval nutrition may endure and impact negatively young juvenile stages (Hentschel and Emlet 2000; Torres et al. 2016), it is possible that the strength of recruit cohorts would not reflect reproductive effort over the year. Residual reproduction during the non-breeding season, from May to 
November (Barbosa et al. 2016), may conceivably contribute disproportionately more to the ingress of recruits reaching maturity.

The importance of out-of-season cohorts apparently starts at embryogenesis. Our results suggest that mothers do not generally manipulate resource allocation during the cooler months, in contrast to reproductive responses upon heat stress typical of summer months, when mothers anticipate their fitness by transferring surplus resources to larvae (Freuchet et al. 2015). Instead, favorable nearshore trophic conditions for adults in winter likely translate directly to the production of higher quality larvae, capable to withstand food privation over the first few days. In turn, these larvae may also encounter a more benign trophic environment while in the plankton, since the diets of adults and larvae overlap to a large extent, likely resulting in lower planktonic mortality and improved early benthic performance. Lower thermal stress on the rocky intertidal may also contribute to out-of-season cohort strength. Results also indicate that offspring released during the main season will not, on average, receive additional maternal resources, compatible to an anticipatory maternal effect (Marshall and Uller 2007; Crean and Marshall 2009) potentially matching the quality observed during the non-breeding period. Larvae produced during the summer will be therefore more numerous but their quality will be lower.

The study region is under the influence of the Brazilian Current, which changes its strength of influence seasonally, bringing warm oligotrophic waters closer to the coast during the summer months (Silva Jr et al. 1996; Longhurst 1998). Although some primary productivity enhancement might be expected during this season due to the (localized and usually brief) South Atlantic Coastal Waters (SACW) upwelling events (Guenther et al. 2008), this condition do not 
seem to be constant, as demonstrated by Ciotti and colleagues (2010). In fact, passing cold fronts during the cooler season (remote wind forcing) may be responsible for extensive vertical mixing which will, in turn, enhance primary production on the study area, as our data supports.

In spite of the clearly consistent spatial structure of CHL and POC observed for the sampled region, spatial patterns explained less of the variation found on the barnacles reproduction. Within seasons, the spatial structure of fecundity could not be assessed in this study. It is possible that other sources of environmental variation not measured here, such as tidal amplitude cycles or stochastic physical oscillations could blur such spatial pattern, but there was a clear spatial structure of larval quality. Larval survival increased from summer-early autumn to winter, aligned to POC and CHL. But shore ranks of larval quality do not exactly match ranks of POC / CHL, as can be noticed in the results from Cambury site, for example. During the winter, larvae produced by parental population in this site survived the longest, but the trophic input there was one of the lowest. Also, the less variable environmental conditions during summer may dampen effects and result in a less structured spatial pattern of reproductive parameters. Spatial contrasts would matter the most out of the main breeding season, when larval quality also showed larger variation across sites.

When spatial and temporal variation was put together to test for correlations there is some evidence that quality and quantity of released larvae tend to be inversely related. Also, larval quality is generally correlated to better trophic conditions. But there is important within-season scatter on our results, perhaps due to methodological limitations (satellite imagery based on a spatial resolution that is too coarse) or natural food supply oscillations. It is possible that 
larval quality respond to some threshold levels, that is, below some critical low level of pelagic resources larvae cannot get any worse, or, the opposite above some food supply quality cannot further increase (Thompson and Harrison 1992). Further studies need to be performed in order to demonstrate such trade-off between number and quality of nauplii produced by these barnacles, but we here could expose how larval quality varies with season with a close relation to the amount of food available for parental populations. Such relationship might promote effects on recruitment success and timing, thus having an impact on chthamalid populations at tropical shores. 


\section{Bibliography}

Aguiar V, Braga E (2007) Seasonal and tidal variability of phosphorus along a salinity gradient in the heavily polluted estuarine system of Santos/São Vicente - São Paulo, Brazil. Mar Pollut Bull 54:464-471. doi: 10.1016/j.marpolbul.2006.11.001

Allen R, Buckley Y, Marshall D (2008) Offspring Size Plasticity in Response to Intraspecific Competition: An Adaptive Maternal Effect across Life- History Stages. Am Nat 171:225-237. doi: 10.1086/524952

Anderson D (1994) Barnacles - Structure, function, development and evolution.

Anger K (2001) The biology of decapod crustacean larvae.

Anger K, Dawris R (1981) Influence of starvation on the larval development of Hyras araneus (Decapoda, Majidae). Helgolander Meeresuntersuchungen 34:287-311.

Anil A, Desai D, Khandeparker L (2001) Larval development and metamorphosis in Balanus amphitrite Darwin (Cirripedia; Thoracica): significance of food concentration, temperature and nucleic acids. J Exp Mar Bio Ecol 263:125-141. doi: 10.1016/S0022-0981(01)00280-5

Anil A, Kurian J (1996) Influence of food concentration, temperature and salinity on the larval development of Balanus amphitrite. Mar Biol 127:115-124. doi: 10.1007/BF00993651

Arrontes J, Arenas F, Fernández C, et al (2004) Effect of grazing by limpets on mid-shore species assemblages in northern Spain. Mar Ecol Prog Ser 277:117-133. doi: 10.3354/meps277117

Barbosa A, Gomes C, Pereira G, et al (2016) Local biological drivers, not remote forcing, predict settlement rate to a subtropical barnacle population. Mar Ecol Prog Ser. doi: 10.3354/meps11589

Barnes H (1972) The seasonal changes in body weight and biochemical composition of the warm-temperate cirripede Chthamalus stellatus(Poli). J Exp Mar Bio Ecol 8:89-100.

Barnes H, Barnes M (1965) Egg size, nauplius size, and their variation with local, geographical, and specific factors in some common cirripedes. J Anim Ecol 34:391-402.

Barnes H, Barnes M (1968) Egg numbers, metabolic efficiency of egg production and fecundity; local and regional variations in a number of common cirripedes. J Mar Biol Ecol 2:135-153.

Barnes H, Barnes M (1959) A comparison of the annual growth patterns of Balanus balanoides (L.) with particular reference to the effect of food and temperature. Oikos 10:1-18.

Barnes H, Crisp D (1956) Evidence of self-fertilization in certain species of barnacles. J Mar Biol Assoc UK 35:631-639.

Barnes M (1989) Egg production in cirripedes. Oceanography and Marine Biology: an Annual Review. pp 91-166 
Basch L, Pearse J (1995) Consequences of larval feeding environment for settlement and metamorphosis of a temperate echinoderm. Oceanol acta 19:273-285.

Bay L, Buechler K, Gagliano M, Caley M (2006) Intraspecific variation in the pelagic larval duration of tropical reef fishes. J Fish Biol 68:1206-1214. doi: 10.1111/j.0022-1112.2006.01016.x

Beckerman A, Benton T, Lapsley C, Koesters N (2006) How effective are maternal effects at having effects? Proc R Soc B 273:485-93. doi: 10.1098/rspb.2005.3315

Benedetti-Cecchi L (2000) Predicting Direct and Indirect Interactions during Succession in a Mid-Littoral Rocky Shore Assemblage. Ecol Monogr 70:45-72.

Benkendorfer G, Soares-Gomes A (2009) Biogeography and biodiversity of gastropod molluscs from the eastern Brazilian continental shelf and slope. Lat Am J Aquat Res 37:143-159. doi: 10.3856/vol37-issue2-fulltext-3

Berkeley S, Chapman C, Sogard S (2004) Maternal Age as a Determinant of Larval Growth and Survival in a Marine Fish, Sebastes melanops. Ecology 85:12581264.

Bernardo J (1996) Maternal effects in animal ecology. Am Zool 36:83-105.

Bertness M (1989) INTRASPECIFIC COMPETITION AND FACILITATION IN A NORTHERN ACORN BARNACLE POPULATION '. Ecology 70:257-268.

Bertness M, Gaines S, Bermudez D, Sanford E (1991) Extreme spatial variation in the growth and reproductive output of the acorn barnacle Semibalanus balanoides. Mar Ecol Prog Ser 75:91-100. doi: 10.3354/meps075091

Bertness M, Gaines S, Stephens E, Yund P (1992) Components of recruitment in populations of the acorn barnacle Semibalanus balanoides (Linnaeus). J Exp Mar Bio Ecol 156:199-215. doi: 10.1016/0022-0981(92)90246-7

Bertness M, Gaines S, Yeh S (1998) Making Mountains out of Barnacles : The Dynamics of Acorn Barnacle Hummocking. Ecology 79:1382-1394.

Bertram D, Strathmann R (1998) Effects of maternal and larval nutrition on growth and form of planktotrophic larvae. Ecology 79:315-327.

Bingham B (1992) Life Histories in an Epifaunal Community: Coupling of Adult and Larval Processes. Ecology 73:2244-2259.

Bivand R, Keitt T, Rowlingson B (2015) rgdal: Bindings for the Geospatial Data AbstractionLibrary. $\mathrm{R}$ package version 1.1-3.

Boidron-Metairon I (1988) Morphological plasticity in laboratory-reared echinoplutei of Dendraster excentricus (Eschscholtz) and Lytechinus variegatus (Lamarck) in response to food conditions. J Exp Mar Bio Ecol 119:31-41. doi: 10.1016/00220981(88)90150-5

Bolton T, Havenhand J (2005) Physiological acclimation to decreased water temperature and the relative importance of water viscosity in determining the feeding performance of larvae of a serpulid polychaete. J Plankton Res 27:875-879. doi: 10.1093/plankt/fbi060

Bonetti C, Bonetti Filho J, Braga E (2000) INTEGRATION OF BIOLOGICAL, RADIOMETRIC AND CHEMICAL-ANALYTIC METHODOLOGIES TO THE 
ASSESSMENT OF ESTUARINE. Sustainable use of estuaries and mangroves: Challenges and prospects.

Botello G, Krug P (2006) 'Desperate larvae' revisited: age, energy and experience affect sensitivity to settlement cues in larvae of the gastropod Alderia sp. Mar Ecol Prog Ser 312:149-159. doi: 10.3354/meps312149

Braga E, Bonetti C, Burone L, Bonetti Filho J (2000) Eutrophication and Bacterial Pollution Caused by Industrial and Domestic Wastes at the Baixada Santista Estuarine System - Brazil. Mar Pollut Bull 40:165-173. doi: 10.1016/S0025326X(99)00199-X

Bruno J, Stachowicz J, Bertness M (2003) Inclusion of facilitation into ecological theory. Trends Ecol Evol 18:119-125. doi: 10.1016/S0169-5347(02)00045-9

Bueno M, Moser G, Tocci B, Flores A (2010) Retention-favorable timing of propagule release in barnacles and periwinkles. Mar Ecol Prog Ser 414:155-165. doi: 10.3354/meps08715

Burrows M, Hawkins S, Southward A (1992) A comparison of reproduction in cooccurring chthamalid barnacles, Chthamalus stellatus (Poli) and Chthamalus montagui Southward. J Exp Mar Bio Ecol 160:229-249. doi: 10.1016/00220981(92)90240-B

Bustamante R, Branch G (1996) Large scale patterns and trophic structure of southern African rocky shores: the role of geographic variation and wave exposure. $\mathbf{J}$ Biogeogr 23:339-351. doi: 10.1046/j.1365-2699.1996.00026.x

Caley M, Carr M, Hixon M, et al (1996) Recruitment and the local dynamics of open marine populations. Annu Rev Ecol Evol Syst 27:477-500. doi:

10.1146/annurev.ecolsys.27.1.477

Carpenter S (1988) Complex Interactions in Lake Communities.

Ciotti Á, Garcia C, Jorge D (2010) Temporal and meridional variability of Satelliteestimates of surface chlorophyll concentration over the Brazilian continental shelf. Pan-American J ... 5:236-253.

Cole SW, Scrosati R, Tam J, Sussmann A (2011) Regional decoupling between NW Atlantic barnacle recruit and adult density is related to changes in pelagic food supply and benthic disturbance. J Sea Res 65:33-37. doi: 10.1016/j.seares.2010.06.006

Connell J (1985) The consequences of variation in initial settlement vs. post-settlement mortality in rocky intertidal communities. J Exp Mar Bio Ecol 93:11-45. doi: 10.1016/0022-0981(85)90146-7

Connell J (1961a) The influence of interspecific competition and other factors on the distribution of the barnacle Chthamlaus stellatus. Ecology 42:235-254.

Connell J (1961b) Effects of competition, predation by Thais lapillus, and other factors on natural populations of the barnacle Balanus balanoides. Ecol Monogr 31:61-104.

Connell J (1972) Community Interactions on MarineCommunity Interactions on Marine Rocky Intertidal Shores. Annu Rev Ecol Syst 3:169-192.

Crean A, Marshall D (2009) Coping with environmental uncertainty: dynamic bet hedging as a maternal effect. Philos Trans R Soc Lond B Biol Sci 364:1087-1096. doi: 
10.1098/rstb.2008.0237

Cushing D (1990) Plankton production and year-class strength in fish populations: an update of the match/mismatch hypothesis. Adv Mar Biol 249-293.

Dando P, Southward A (1980) A new species of Chthamalus (Crustacea: Cirripedia) characterized by enzyme electrophoresis and shell morphology: with a revision of other species of Chthamalus from the western shores of the atlantic ocean. J Mar Biol Assoc United Kingdom 60:787. doi: 10.1017/S0025315400040455

Desai D, Anil A, Venkat K (2006) Reproduction in Balanus amphitrite Darwin (Cirripedia: Thoracica): influence of temperature and food concentration. Mar Biol 149:1431-1441. doi: 10.1007/s00227-006-0315-3

Diss A, Kunkel J, Montgomery M, Leonard D (1996) Effects of maternal nutrition and egg provisioning on parameters of larval hatch, survival and dispersal in the gypsy moth, Lymantria dispar L. Oecologia 106:470-477. doi: 10.1007/BF00329704

Dixon P, Milicich M, Sugihara G (1999) Episodic Fluctuations in Larval Supply. Science (80- ) 283:1528-1530. doi: 10.1126/science.283.5407.1528

Dormann C, Elith J, Bacher S, et al (2013) Collinearity: A review of methods to deal with it and a simulation study evaluating their performance. Ecography (Cop) 36:027046. doi: 10.1111/j.1600-0587.2012.07348.x

Dugdale R (1972) Chemical Oceanography and Primary Productivity in Upwelling Regions.

Dungan M (1986) Three-Way Interactions: Barnacles, Limpets and Algae in a Sonoran Desert Rocky Intertidal Zone. Am Nat 127:292-316. doi: 10.1086/284486

Falkowski P, Dubinsky Z, Santostefano G (1985) Light-enhanced dark respiration in phytoplankton. Verh Internat Verein Limnol 22:2830-2833.

Farrapeira C (2010) Shallow water Cirripedia of the northeastern coast of Brazil: The impact of life history and invasion on biogeography. J Exp Mar Bio Ecol 392:210 219. doi: 10.1016/j.jembe.2010.04.021

Farrapeira C (2008) Cirripedia Balanomorpha del estuario del Río Paripe (Isla de Itamaracá, Pernambuco, Brasil). Biota Neotrop 8:31-39. doi: 10.1590/S167606032008000300002

Fenaux L, Strathmann M, Strathmann R (1994) Five tests of food-limited growth of larvae in coastal waters by comparisons of rates of development and form of echinoplutei. Limnol Oceanogr 39:84-98. doi: 10.4319/lo.1994.39.1.0084

Floeter S, Soares-Gomes A (1999) Biogeographic and Species Richness Patterns of Gastropoda on the Southwestern Atlantic. Rev Bras Biol 59:567-575.

Flores A, Christofoletti R, Peres A, et al (2015) Interactive effects of grazing and environmental stress on macroalgal biomass in subtropical rocky shores: Modulation of bottom-up inputs by wave action. J Exp Mar Bio Ecol 463:39-48. doi: 10.1016/j.jembe.2014.11.001

Foster B (1987) Barnacle ecology and adaptation. Barnacle Biology. pp 113 - 133

Foster B (1971a) Desiccation as a factor in the intertidal zonation of barnacles. Mar Biol 8:12-29. doi: 10.1007/BF00349341 
Foster B (1971b) On the determinants of the upper limit of intertidal distribution of barnacles (Crustacea: Cirripedia). J Anim Ecol 40:33-48. doi: 10.2307/3328

Fox C, Thakar M, Mousseau T (1997) The Evolutionary Genetics of an Adaptive Maternal Effect : Egg Size Plasticity in a Seed Beetle. 149:149-163.

Freuchet F, Tremblay R, Flores A (2015) Interacting environmental stressors modulate reproductive output and larval performance in a tropical intertidal barnacle. Mar Ecol Prog Ser 532:161-175. doi: 10.3354/meps11377

Gaeta S, Ribeiro S, Metzler P, et al (1999) Environmental forcing on phytoplankton biomass and primary productivity of the coastal ecosystem in Ubatuba region, southern Brazil. Rev Bras Oceanogr 47:11-27.

Gagliano M, McCormick M (2007) Maternal condition influences phenotypic selection on offspring. J Anim Ecol 76:174-182. doi: 10.1111/j.1365-2656.2006.01187.x

Gaines S, Brown S, Roughgarden J (1985) Spatial variation in larval concentrations as a cause of spatial variation in settlement for the barnacle, Balanus glandula. Oecologia 67:267-272. doi: 10.1007/BF00384297

Gaines S, Hudson G, Krenz C, et al (2003) Coastal oceanography sets the pace of rocky intertidal community dynamics. Proc Natl Acad Sci U S A 100:12229-12234. doi: 10.1073/pnas. 1534875100

Gaines S, Roughgarden J (1985) Larval settlement rate: A leading determinant of structure in an ecological community of the marine intertidal zone. Proc Natl Acad Sci U S A 82:3707-11.

Garrabou J, Coma R, Bensoussan N, et al (2009) Mass mortality in Northwestern Mediterranean rocky benthic communities: Effects of the 2003 heat wave. Glob Chang Biol 15:1090-1103. doi: 10.1111/j.1365-2486.2008.01823.x

Garrabou J, Perez T, Sartoretto S, Harmelin J (2001) Mass mortality event in red coral Corallium rubrum populations in the Provence region (France, NW Mediterranean). Mar Ecol Prog Ser 217:263-272. doi: 10.3354/meps217263

Gianesella S, Kutner M, Saldanha-Corrêa F, Pompeu M (1999) Assessment of plankton community and environmental conditions in São Sebastião Channel prior to the construction of a produced water outfall. Rev Bras Oceanogr 47:29-46.

Giordano F (2008) Zoobenthos of the Santos estuarine system. PERSPECTIVES ON INTEGRATED COASTAL ZONE MANAGEMENT IN SOUTH AMERICA.

Giordano F, Borges R, Santos J, Rosso S (2013) Recrutamento e colonização de cirripédios Balanus trigonus em painéis artificiais em águas estuarinas de SantosSP , Brasil : um estudo de 45 meses . Cirriped Balanus trigonus colonization and recruitment in artificial panels in estuarine waters in Santos. Bioscience 2:35-41.

Gosselin L, Chia F (1996) Prey selection by inexperienced predators: Do early juvenile snails maximize net energy gains on their first attack? J Exp Mar Bio Ecol 199:4558. doi: 10.1016/0022-0981(95)00190-5

Gosselin L, Qian P (1996) Early post-settlement mortality of an intertidal barnacle: a critical period for survival. Mar Ecol Prog Ser 135:69-75.

Griffith K, Giménez L, Jenkins S (2011) Climate driven changes in recruitment success of marine invertebrates: The role of food supply. ICES CM 2011. 
Guenther M, Gonzalez-Rodriguez E, Carvalho W, et al (2008) Plankton trophic structure and particulate organic carbon production during a coastal downwelling-upwelling cycle. Mar Ecol Prog Ser 363:109-119. doi: 10.3354/meps07458

Guiler E (1955) Australian Intertidal Belt-Forming Species in Tasmania. J Ecol 43:138148.

Harley C (2006) Effects of physical ecosystem engineering and herbivory on intertidal community structure. Mar Ecol Prog Ser 317:29-39. doi: 10.3354/meps317029

Harley C (2008) Tidal dynamics, topographic orientation, and temperature-mediated mass mortalities on rocky shores. Mar Ecol Prog Ser 371:37-46. doi: 10.3354/meps07711

Hawkins S, Jones H (1992) Rocky Shores (Vol. 1).

Helm M, Bourne N, Lovatelli A (2004) Hatchery culture of bivalves: A practical manual. Rome

Helmuth B, Broitman B, Blanchette C, et al (2006) Mosaic Patterns of Thermal Stress in the Rocky Intertidal Zone: Implications for Climate Change. Ecol Monogr 76:461479. doi: 10.1890/0012-9615(2006)076[0461:MPOTSI]2.0.CO;2

Helmuth BS, Hofmann GE (2001) Microhabitats, thermal heterogeneity, and patterns of physiological stress in the rocky intertidal zone. Biol Bull 201:374-84.

Hentschel B, Emlet R (2000) Metamorphosis of barnacle nauplii: effects of food variability and a comparison with amphibian models. Ecology 81:3495-3508.

Hijmans R (2015) No Title raster: Geographic Data Analysis and Modeling. R package version 2.5-2.

Hines A (1978) Reproduction in three species of intertidal barnacles from central California. Biol Bull 154:262-281.

Hixon M, Pacala S, Sandin S (2002) Population regulation: historical context and contemporary challenges of open vs. closed systems. Ecology 83:1490-1508. doi: 10.1890/0012-9658(2002)083[1490:PRHCAC]2.0.CO;2

Hu C, Lee Z, Franz B (2012) Chlorophyll a algorithms for oligotrophic oceans: A novel approach based on three-band reflectance difference. J Geophys Res Ocean 117:125. doi: 10.1029/2011JC007395

Hughes T, Baird A, Dinsdale E, et al (2000) Supply-Side Ecology Works Both Ways: The Link between Benthic Adults, Fecundity, and Larval Recruits. Ecology 81:22412249. doi: $10.2307 / 177111$

Hutchins L (1947) The bases for temperature zonation in geographical distribution. Ecol Monogr 17:325-335. doi: 10.2307/1948663

Jarrett J (2003) Seasonal Variation in Larval Condition and Postsettlement Performance of the Barnacle Semibalanus Balanoides. Ecology 84:384-390. doi: 10.1890/00129658(2003)084[0384:SVILCA]2.0.CO;2

Jarrett J, Pechenik J (1997) Temporal Variation in Cyprid Quality and Juvenile Growth Capacity for an Intertidal Barnacle. Ecology 78:1262-1265. doi: 10.1890/00129658(1997)078[1262:TVICQA]2.0.CO;2

Jenkins S (2005) Larval habitat selection, not larval supply, determines settlement patterns 
and adult distribution in two chthamalid barnacles. J Anim Ecol 74:893-904. doi: 10.1111/j.1365-2656.2005.00985.x

Jonsson P, Berntsson K, Larsson A (2004) Linking Larval Supply To Recruitment: FlowMediated Control of Initial Adhesion of Barnacle Larvae. Ecology 85:2850-2859. doi: 10.1890/03-0565

Kasten P, Flores A (2013) Disruption of endogenous tidal rhythms of larval release linked to food supply and heat stress in an intertidal barnacle. Mar Ecol Prog Ser 472:185-198. doi: 10.3354/meps 10005

Kjerfve B, Ribeiro C, Dias G, et al (1997) Oceanographic characteristics of an impacted coastal bay: Baía de Guanabara, Rio de Janeiro, Brazil. Cont Shelf Res 17:16091643. doi: 10.1016/S0278-4343(97)00028-9

Klôh A, Farrapeira C, Rigo A, Rocha R (2013) Intertidal native and introduced barnacles in Brazil: distribution and abundance. Mar Biodivers Rec 6:e102. doi: $10.1017 / \mathrm{S} 1755267213000766$

Kokkinakis S, Wheeler P (1987) Nitrogen uptake and phytoplankton growth in coastal upwelling regions. Limnol Oceanogr 32:1112-1123. doi: 10.4319/lo.1987.32.5.1112

Krug P (2001) Bet-hedging dispersal strategy of a specialist marine herbivore: A settlement dimorphism among sibling larvae of Alderia modesta. Mar Ecol Prog Ser 213:177-192. doi: 10.3354/meps 213177

Lang W, Marcy M (1982) SOME EFFECTS OF EARLY STARVATION ON THE SURVIVAL IMPROVISUS. J Exp Mar Bio Ecol 60:63-70.

Leonard G, Levine J, Schmidt P, Bertness M (1998) Flow-Driven Variation in Intertidal Community Structure in a Maine Estuary. Ecology 79:1395-1411. doi: $10.2307 / 176751$

Leslie H (2005) Positive intraspecific effects trump negative effects in high-density barnacle aggregations. Ecology 86:2716-2725. doi: 10.1890/04-1767

Leslie H, Breck E, Chan F, et al (2005a) Barnacle reproductive hotspots linked to nearshore ocean conditions. Proc Natl Acad Sci U S A 102:10534-9. doi: 10.1073/pnas.0503874102

Leslie H, Breck E, Chan F, et al (2005b) Barnacle reproductive hotspots linked to nearshore ocean conditions. Proc Natl Acad Sci U S A 102:10534-10539. doi: 10.1073/pnas.0503874102

Letcher B, Rice J, Crowder L, Rose K (1996) Variability in survival of larval fish: disentangling components with a generalized individual-based model. Can J Fish Aquat Sci 53:787-801. doi: 10.1139/f95-241

Lewis J (1964) The ecology of rocky shores.

Longhurst A (1998) Ecological and Geography of the Sea.

López D, González M (2003) Density-dependent effects in Jehlius cirratus (Darwin, 1854) (Cirripedia: Chthamalidae) under different growth conditions. Mar Ecol 24:289302. doi: 10.1046/j.1439-0485.2003.00851.x

López M, Coutinho R (2008) Acoplamento Plâncton-Bentos: O Papel Do Suprimento 
Larval Na Estrutura Das Comunidades Bentônicas De Costões Rochosos. Oecologia Bras 12:575-601. doi: 10.4257/oeco.2009.1204.01

Lorenzen C (1966) A method for the continuous measurement of in vivo chlorophyll concentration. Deep Sea Res Oceanogr Abstr 13:223-227. doi: 10.1016/00117471(66)91102-8

Marshall D, Bolton T, Keough M (2003) Offspring size affects the post-metamorphic performance of a colonial marine invertebrate. Ecology 84:3131-3137.

Marshall D, Bonduriansky R, Bussière L (2008) Offspring size variation within broods as a bet-hedging strategy in unpredictable environments. Ecology 89:2506-2517.

Marshall D, Keough M (2004) When the going gets rough: effect of maternal size manipulation on larval quality. Mar Ecol Prog Ser 272:301-305. doi: 10.3354/meps272301

Marshall J, Uller T (2007) When is a maternal effect adaptive? Oikos 116:1957-1963. doi: 10.1111/j.2007.0030-1299.16203.x

Mcclintock J, Stephen A (1990) The effects of photoperiod on gametogenesis in the tropical sea urchin Eucidaris tribuloides ( Lanmrck ) ( Echinodermata : Echinoidea ). J Exp Mar Bio Ecol 139:175-184.

Menge B a, Olson AM, Dahlhoff EP (2002) Environmental Stress, Bottom-up Effects, and Community Dynamics: Integrating Molecular-Physiological and Ecological Approaches. Integr Comp Biol 42:892-908. doi: 10.1093/icb/42.4.892

Menge B, Daley B, Wheeler P, et al (1997) Benthic-pelagic links and rocky intertidal communities: bottom-up effects on top-down control? Proc Natl Acad Sci U S A 94:14530-14535. doi: 10.1073/pnas.94.26.14530

Metzler P, Glibert P, Gaeta S, Ludlam J (1997) New and regenerated production in the South Atlantic off Brazil. Deep Res I 44:363-384.

Miller S, Morgan S (2013) Phenotypic plasticity in larval swimming behavior in estuarine and coastal crab populations. J Exp Mar Bio Ecol 449:45-50. doi: 10.1016/j.jembe.2013.08.013

Minchinton T, Scheibling R (1991) The Influence of Larval Supply and Settlement on the Population Structure of Barnacles. Ecology 72:1867-1879.

Moran A, Emlet R (2001) Offspring Size and Performance in Variable Environments: Field Studies on a Marine Snail. Ecology 82:1597-1612. doi: 10.2307/2679803

Moser G, Sigaud-Kutner T, Cattena C, et al (2004) Algal growth potential as an indicator of eutrophication degree in coastal areas under sewage disposal influence. Aquat Ecosyst Health Manag 7:115-126. doi: 10.1080/14634980490281443

Navarrete S, Wieters E, Broitman B, Castilla J (2005) Scales of benthic-pelagic coupling and the intensity of species interactions: from recruitment limitation to top-down control. Proc Natl Acad Sci U S A 102:18046-18051. doi: 10.1073/pnas.0509119102

Navarro J, Thompson R (1996) Physiological energetics of the horse mussel Modiolus modiolus in a cold ocean environment. Mar Ecol Prog Ser 138:135-148. doi: $10.3354 /$ meps 138135 
Newell R (1970) Biology of intertidal animals.

O'Riordan R, Myers A, Cross T (1995) The reproductive cycles of Chthamalus stellatus (Poli) and C. montagui Southward in south-western Ireland. J Exp Mar Bio Ecol 190:17-38. doi: 10.1016/0022-0981(95)00029-Q

O’Riordan R, Power A, Myers A (2010) Factors, at different scales, affecting the distribution of species of the genus Chthamalus Ranzani (Cirripedia, Balanomorpha, Chthamaloidea). J Exp Mar Bio Ecol 392:46-64. doi: 10.1016/j.jembe.2010.04.010

Olson R, Olson M (1989) Food Limitation of Planktotrophic Marine Invertebrate Larvae: Does it Control Recruitment Success? Annu. Rev. Ecol. Syst.

Orton J (1920) Sea-Temperature, Breeding and Distribution in Marine Animals. J Mar Biol Assoc UK (New Ser 12:339-366. doi: 10.1017/S0025315400000102

Page H (1984) Local variation in reproductive patterns of two species of intertidal barnacles, Pollicipes polymerus Sowerby and Chthamalus fissus Darwin. J Exp Mar Bio Ecol 74:259-272.

Palmer A, Strathmann R (1981) Scale of dispersal in varying environments and its implications for life histories of marine invertebrates. Oecologia 48:308-318.

Patel B, Crisp D (1960) Rates of development of the embryos of several species of barnacles. Physiol Zool 33:104-119.

Pechenik J (1990) Delayed metamorphosis by larvae of benthic marine invertebrates : Does it occur? Is there a price to pay? Ophelia 32:63-94.

Pechenik J (2006) Larval experience and latent effects--metamorphosis is not a new beginning. Integr Comp Biol 46:323-333. doi: 10.1093/icb/icj028

Pechenik J, Estrella M, Hammer K (1996) Food limitation stimulates metamorphosis of competent larvae and alters postmetamorphic growth rate in the marine prosobranch gastropod Crepidula fornicata. Mar Biol 127:267-275. doi: 10.1007/BF00942112

Pechenik J, Gleason T, Daniels D, Champlin D (2001) Influence of larval exposure to salinity and cadmium stress on juvenile performance of two marine invertebrates (Capitella sp. I and Crepidula fornicata). J Exp Mar Bio Ecol 264:101-114. doi: 10.1016/S0022-0981(01)00313-6

Pechenik J, Jarrett J, Rooney J (2002) Relationships between larval nutritional experience, larval growth rates, juvenile growth rates, and juvenile feeding rates in the prosobranch gastropod Crepidula fornicata. J Exp Mar Bio Ecol 280:63-78. doi: 10.1016/S0022-0981(02)00367-2

Pechenik J, Tyrell A (2015) Larval diet alters larval growth rates and post-metamorphic performance in the marine gastropod Crepidula fornicata. Mar Biol. doi: 10.1007/s00227-015-2696-7

Pechenik J, Wendt D, Jarrett J (1998) Metamorphosis Is Not a New Beginning Larval experience influences juvenile performance. Bioscience 48:901-910.

Pepin P, Myers R (1991) Significance of Egg and Larval Size to Recruitment Variability of Temperate Marine Fish. Can J Fish Aquat Sci 48:1820-1828. doi: 10.1139/f91215 
Persson L, Bengtsson J, Menge B, Power M (1995) Food Webs: Integration of Patterns \& Dynamics.

Pfaff M, Branch G, Wieters E, et al (2011) Upwelling intensity and wave exposure determine recruitment of intertidal mussels and barnacles in the southern Benguela upwelling region. Mar Ecol Prog Ser 425:141-152. doi: 10.3354/meps09003

Pfeiffer-Hoyt A, Mcmanus M (2005) Modeling the effects of environmental variability on Balanus glandula larval development. J Plankton Res 27:1211-1228. doi: 10.1093/plankt/fbi089

Phillips N (2005) Growth of filter-feeding benthic invertebrates from a region with variable upwelling intensity. Mar Ecol Prog Ser 295:79-89. doi:

10.3354/meps295079

Phillips N (2004) Variable Timing of Larval Food Has Consequences for Early Juvenile Performance in a Marine Mussel. Ecology 85:2341-2346. doi: 10.1890/03-3097

Phillips N (2006) Natural variability in size and condition at settlement of 3 species of marine invertebrates. Integr Comp Biol 46:598-604. doi: 10.1093/icb/ic1008

Phillips N (2002) Effects of nutrition-mediated larval condition on juvenile performance in a marine mussel. Ecology 83:2562-2574.

Pierce D (2015) ncdf4: Interface to Unidata netCDF (version 4 or earlier) format data files. Rpackage version 1.15 .

Pilsbry H (1916) The sessile barnacles (cirripedia) contained in the collections of the U.S. National museum; including a monograph oh the american species.

Pineda J (1994) Spatial and temporal patterns in barnacle settlement rate along a Southern California rocky shore. Mar Ecol Prog Ser 107:125-138. doi: 10.3354/meps 107125

Pineda J, Porri F, Starczak V, Blythe J (2010) Causes of decoupling between larval supply and settlement and consequences for understanding recruitment and population connectivity. J Exp Mar Bio Ecol 392:9-21. doi: 10.1016/j.jembe.2010.04.008

Pineda J, Reyns N, Starczak V (2009) Complexity and simplification in understanding recruitment in benthic populations. Popul Ecol 51:17-32. doi: 10.1007/s10144008-0118-0

Pitombo F, Burton R (2007) Systematics and Biogeography of Tropical Eastern Pacific Chthamalus with Descriptions of Two New Species (Cirripedia, Thoracica). Zootaxa 1-30.

Pitt N, Poloczanska E, Hobday A (2010) Climate-driven range changes in Tasmanian intertidal fauna. Mar Freshw Res 61:963-970. doi: 10.1071/MF09225

Poorbagher H, Lamare M, Barker M (2010) The relative importance of parental nutrition and population versus larval diet on development and phenotypic plasticity of Sclerasterias mollis larvae. J Mar Biol Assoc United Kingdom 90:527-536. doi: 10.1017/S0025315409990907

Raimondi P (1990) Patterns, mechanisms, consequences of variability in settlement and recruitment of an intertidal barnacle. Ecol Monogr 60:283-309.

Reznick D, Callahan H, Llauredo R (1996) Maternal Effects on Offspring Quality in 
Poeciliid Fishes. Am Zool 36:147-156.

Reznick D, Yang A (1993) The influence of fluctuating resources on life history patterns of allocation and plasticity in female guppies. Ecology 74:2011-2019.

Roughgarden J, Gaines S, Possingham H (1988) Recruitment dynamics in complex life cycles. Science (80- ) 241:1460 - 1466.

Sanford E, Bermudez D, Bertness M, Gaines S (1994) Flow, food supply and acorn barnacle population dynamics. Mar Ecol Prog Ser 104:49-62.

Sanford E, Menge B (2001) Spatial and temporal variation in barnacle growth in a coastal upwelling system. Mar Ecol Prog Ser 209:143-157.

Scheltema R, Williams I (1982) Significance of temperature to larval survivial and lenght of development in Balanus eburneus (Crustacea: Cirripedia). Mar Ecol Prog Ser 9:43-49.

Schmiegelow J, Gianesella S, Simonetti C, et al (2008) Primary producers in Santos estuarine system. Perspectives on Integrated Coastal Zone Management in South America. pp 161-174

Schneider A, Rasband W, Eliceiri K (2012) NIH Image to ImageJ: 25 years of image analysis. Nat Methods 9:671-675.

Searcy S, Sponaugle S (2000) Variable larval growth in a coral reef fish. Mar Ecol Ser 206:213-226. doi: 10.3354/meps206213

Shahdadi A, Sari A (2010) Chthamalid barnacles (Cirripedia: Thoracica) of the Persian Gulf and Gulf of Oman, Iran. J Mar Biol Assoc United Kingdom 91:745-753. doi: $10.1017 / \mathrm{S} 0025315410001803$

Shima J, Findlay A (2002) Pelagic larval growth rate impacts benthic settlement and survival of a temperate reef fish. Mar Ecol Prog Ser 235:303-309. doi: $10.3354 /$ meps 235303

Shima J, Swearer S (2009) Larval quality is shaped by matrix effects: implications for connectivity in a marine metapopulation. Ecology 90:1255-1267.

Silva Jr C, Kampel M, Araujo C, Stech J (1996) Observação da penetração do ramo costeiro da corrente das malvinas na costa sul-sudeste do Brasil a patir de imagens AVHRR. Anais VIII Simpósio Brasileiro de Sensoriamento Remoto, Slavador, Brasil. pp 787-793

Sinervo B (1990) The evolution of maternal investment in lizards: an experimental and comparative analysis of egg size and its effects on offspring performance. Evolution (N Y) 44:279-294.

Skinner L, Coutinho R (2010) Preliminary results on settlement of the barnacles Tetraclita stalactifera and Chthamalus bisinuatus on a Brazilian tropical rocky shore under upwelling conditions. Invertebr Reprod Dev 41:151-156. doi: 10.1080/07924259.2002.9652746

Southward A, Crisp D (1956) Flutuations in the Distribution and Abundance of Intertidal Barnacles. J Mar Biol Assoc UK 35:211-229.

Southward A, Newman W (2003) A review of some common Indo-Malayan and western Pacific species of Chthamalus barnacles (Crustacea: Cirripedia). J Mar Biol Assoc 
United Kingdom 83:797-812. doi: 10.1017/S0025315403007835h

Starr M, Himmelman J, Therriault J (1991) Coupling of nauplii release in barnacles with phytoplankton blooms: A parallel strategy to that of spawning in urchins and mussels. J Plankton Res 13:561-571. doi: 10.1093/plankt/13.3.561

Stephens P, Sutherland W, Freekleton R (1999) What is the Allee effect? Oikos 87:185190.

Stramski D, Reynolds R, Babin M, et al (2007) Relationships between the surface concentration of particulate organic carbon and optical properties in the eastern South Pacific and eastern Atlantic Oceans. Biogeosciences Discuss 4:3453-3530. doi: $10.5194 /$ bgd-4-3453-2007

Strathmann R (1985) Feeding and Nonfeeding Larval Development and Life-History Evolution in Marine Invertebrates. Annu Rev Ecol Syst 16:339-361. doi: 10.1146/annurev.ecolsys.16.1.339

Sutherland JP (1990) Recruitment regulates demographic variation in a tropical intertidal barnacle. Ecology 71:955-972. doi: 10.2307/1937365

Takanohashi R, Castro N, Pollery R, et al (2014) The influence of surface low-salinity waters and cold subsurface water masses on picoplankton and ultraplankton distribution in the continental shelf of Rio de Janeiro, SE Brazil. Cont Shelf Res 120:82-95. doi: 10.1016/j.csr.2016.02.017

Tanaka M, Duarte L (1998) Recruitment variation of the barnacle Chthamalus bisinuatus Pilsbry 1916 in an exposed rocky shore in southeast Brazil. Bull Mar Sci 62:285292.

Thiyagarajan V, Harder T, Qian P (2002) Relationship between cyprid energy reserves and metamorphosis in the barnacle Balanus amphitrite Darwin (Cirripedia; Thoracica). J Exp Mar Bio Ecol 280:79-93. doi: 10.1016/S0022-0981(02)00415-X

Thiyagarajan V, Harder T, Qian P (2003) Effects of TAG/DNA ratio and age of cyprids on post-metamorphic growth and survival in the barnacle Balanus amphitrite. $\mathrm{J}$ Mar Biol Assoc UK 83:83-88.

Thompson P, Harrison P (1992) Effects of monospecific algal diets of varying biochemical composition on the growth and survival of Pacific oyster (Crassostrea gigas) larvae. Mar Biol 113:645-654. doi: 10.1007/BF00349708

Thorson G (1950) Reproductive and larval ecology of marine bottom invertebrates. Biol Rev 25:1-45. doi: 10.1111/j.1469-185X.1950.tb00585.x

Todd C (1998) Larval supply and recruitment of benthic invertebrates : do larvae always disperse as much as we believe ? Hydrobiologia 375/376:1-21.

Toonen R, Pawlik J (2001) Settlement of the gregarious tube worm Hydroides dianthus (Polychaeta: Serpulidae). II. Testing the desperate larva hypothesis. Mar Ecol Prog Ser 224:115-131. doi: 10.3354/meps224115

Torres G, Giménez L, Pettersen A, et al (2016) Persistent and context-dependent effects of the larval feeding environment on post-metamorphic performance through the adult stage. Mar Ecol Prog Ser 545:147-160. doi: 10.3354/meps11586

Toupoint N, Gilmore-Solomon L, Bourque F, et al (2012) Match/mismatch between the Mytilus edulis larval supply and seston quality: effect on recruitment. Ecology 
93:1922-1934. doi: 10.1890/11-1292.1

Underwood A (1997) Experiments in Ecology - Their logical design and interpretation using analysis of variance.

Vance R (1973) On reproductive strategies in marine benthic invertebrates. Am Nat 107:339-352.

Voss R, Clemmesen C, Baumann H, Hinrichsen H (2006) Baltic sprat larvae: Coupling food availability, larval condition and survival. Mar Ecol Prog Ser 308:243-254. doi: $10.3354 /$ meps 308243

Wendt D, Johnson C (2006) Using latent effects to determine the ecological importance of dissolved organic matter to marine invertebrates. Integr Comp Biol 46:634-642. doi: 10.1093/icb/ic1025

Wethey D (1983) Geographic limits and local zonation: the barnacles Semibalanus ( Balanus) and Chthamalus in New England. Biol Bull 165:330-341. doi: 10.1094/PDIS.1999.83.11.1073B

Wethey D (1984) Effects of crowding on fecundity in barnacles: Semibalanus (Balanus) balanoides, Balanus glandula, and Chthamalus dalli. Can J Zool 62:1788-1795. doi: $10.1139 / \mathrm{z} 84-261$

Wilbur H (1980) Complex Life Cycles. Annu Rev Ecol Syst 11:67-93. doi: 10.1146/annurev.es.11.110180.000435

Wisley B (1960) Experiments on Rearing the Barnacle Elminius modestus Darwin to the Settling Stage in the Laboratory. Mar Freshw Res 11:42. doi: 10.1071/MF9600042

Wotton R (1988) Dissolved organic material and trophic dynamics: What is the food of filtering collectors in aquatic ecosystems? Bioscience 38:172-178.

Wu R (1980) Effects of crowding on the energetics of the barnacle Balanus glandula Darwin. Can J Zool 58:559-566. doi: 10.1139/z80-078

Yan Y, Chan B, Williams G (2006) Reproductive development of the barnacle Chthamalus malayensis in Hong Kong: implications for the life-history patterns of barnacles on seasonal, tropical shores. Mar Biol 148:875-887. doi: $10.1007 / \mathrm{s} 00227-005-0117-\mathrm{z}$

Yan Y, Miao S (2004) The Effect of Temperature on the Reproductive Cycle of the Tropical Barnacle, Chthamalus malayensis Pilsbry ( Cirripedia ). Crustaceana 77:205-212.

Young P (1993) The Verrucomorpha Chthamaloidea from the Brazilian coast (Crustacea: Cirripedia). Rev Bras Biol 53:255-267.

Zabin C, Altieri A (2007) A Hawaiian limpet facilitates recruitment of a competitively dominant invasive barnacle. Mar Ecol Prog Ser 337:175-185. doi: 10.3354/meps337175 


\section{CHAPTER 03 - Maternal and pelagic resource allocation shape plastic larval responses affecting recruitment in a tropical barnacle}

\section{Introduction}

Many marine invertebrates undergo a complex life cycle, involving one or more free-living larval phases which metamorphose to a benthic juvenile phase (Wilbur 1980; Roughgarden et al. 1988). These larvae may be either lecithotrophic, maintaining themselves through consumption of the yolk, or planktotrophic, feeding on phytoplankton and other particles (Vance 1973; Strathmann 1985). They can spend from minutes to months in the plankton before reaching competency and metamorphosing to the benthic juvenile stage (Pechenik 1990). Benthic populations may be often recruitment-limited, (Roughgarden et al. 1988; Raimondi 1990; Bertness et al. 1992) with both larval supply and quality of the competent larvae playing major roles in the recruitment process (Gaines et al. 1985; Gaines and Roughgarden 1985; Jarrett and Pechenik 1997; Shima and Findlay 2002; Jarrett 2003). Mechanisms affecting larval supply have been extensively examined (Gaines et al. 1985; Raimondi 1990; Bingham 1992; Bertness et al. 1992; Caley et al. 1996; Todd 1998; Dixon et al. 1999; Hughes et al. 2000; Jonsson et al. 2004 and many more), but processes determining larval quality and its effects on the performance of early benthic juvenile stages are much less understood (Jarrett and Pechenik 1997; Marshall et al. 2003; Jarrett 2003; Phillips 2006). While larval supply to nearshore waters, adjacent to benthic populations has been often considered the key parameter controlling recruitment, some studies had indicated that even slight variations in larval quality can affect 
different components of recruitment such as development rate (Fenaux et al. 1994; Poorbagher et al. 2010), survivorship (Pepin and Myers 1991; Letcher et al. 1996; Voss et al. 2006) and performance of early benthic stages (Jarrett and Pechenik 1997; Pechenik et al. 1998; Phillips 2002; Thiyagarajan et al. 2002; Thiyagarajan et al. 2003; Jarrett 2003; Pechenik 2006; Pechenik and Tyrell 2015).

Larval quality may result from a combination of effects taking place during embryogenesis, which depend on maternal metabolism, and effects occurring during larval development in the plankton. Planktonic factors affecting larval quality include negative effects of prolonged pelagic development and delayed metamorphosis (Pechenik et al. 1998), exposure to pollutants (Pechenik et al. 2001) and changes of environmental conditions (Pfeiffer-Hoyt and Mcmanus 2005; Phillips 2006; Shima and Swearer 2009). Yet, the most important pelagic variable controlling larval quality, and also limiting settlement rate and early recruitment success, is apparently food supply (Olson and Olson 1989; Pechenik et al. 1996; Toupoint et al. 2012; Pechenik and Tyrell 2015).

While food limitation may be relieved in more productive environments, particularly when offspring production is timed with seasonal blooms of primary production (Cushing 1990, Starr et al. 1991), oligotrophic conditions, which usually prevail in tropical marine systems, may impose a severe bottleneck for populations of coastal meroplanktonic invertebrates (Olson and Olson 1989; Fenaux et al. 1994). In such restrictive trophic conditions, one might expect higher plasticity in larval traits, with variable quality of settling larvae and early recruits (Boidron-Metairon 1988; Basch and Pearse 1995; Botello and Krug 2006; Toupoint et al. 2012). Maternal resource allocation is known to largely determine fitness in lecithotrophic larvae (Reznick and Yang 1993; Reznick et al. 1996) and some 
studies have already indicated that maternal inputs may also affect performance of an array of other larvae generally regarded as planktotrophic (Bernardo 1996; Berkeley et al. 2004; Gagliano and McCormick 2007). Feeding conditions of parents frequently correlate to offspring nourishment (Diss et al. 1996; Poorbagher et al. 2010), but maternal manipulation may occur, with disproportionate resource redirection to either parental provision (Bertram and Strathmann 1998) or to the supply of energetic reserves to embryos (e.g. Fox et al. 1997; Allen et al. 2008). Those opposite strategies have been referred to as 'selfish' or 'anticipatory' (Marshall and Uller 2007); the latter making reference to early enhancement of maternal fitness through increased survival and reproductive chances of their offspring.

The interplay between maternal and pelagic allocation may potentially produce extensive morphological, physiological and behavioral larval plasticity. However, key larval traits determining recruitment components (as in Pineda 1994) are not equally prone to environmentally-driven change. In one extreme there are fixed traits, such as the number of larval stages of several crustaceans (Anger 2001) and in the other end extremely variable traits, which respond to multiple environmental factors, such as within-clutch production of both dispersive and non-dispersive larval forms of sea slugs (Krug 2001). For most traits, however, phenotypes vary within intermediate limits, either distributed over a continuous range or constituting canalized discrete states. Examples of the former include pelagic larval duration and growth rates of larval fish (Searcy and Sponaugle 2000; Bay et al. 2006), or swimming speed of crab zoeae (Miller and Morgan 2013), while dual settling preferences of polychaete larvae, with sibling individuals either choosing or avoiding surfaces treated with conspecific cues 
(Toonen and Pawlik 2001), illustrate a case of the latter. We conceive here possible outcomes of joint effects of maternal and pelagic inputs on the variation of 'planktotrophic' larval traits which translate to recruitment components (Fig. 1).

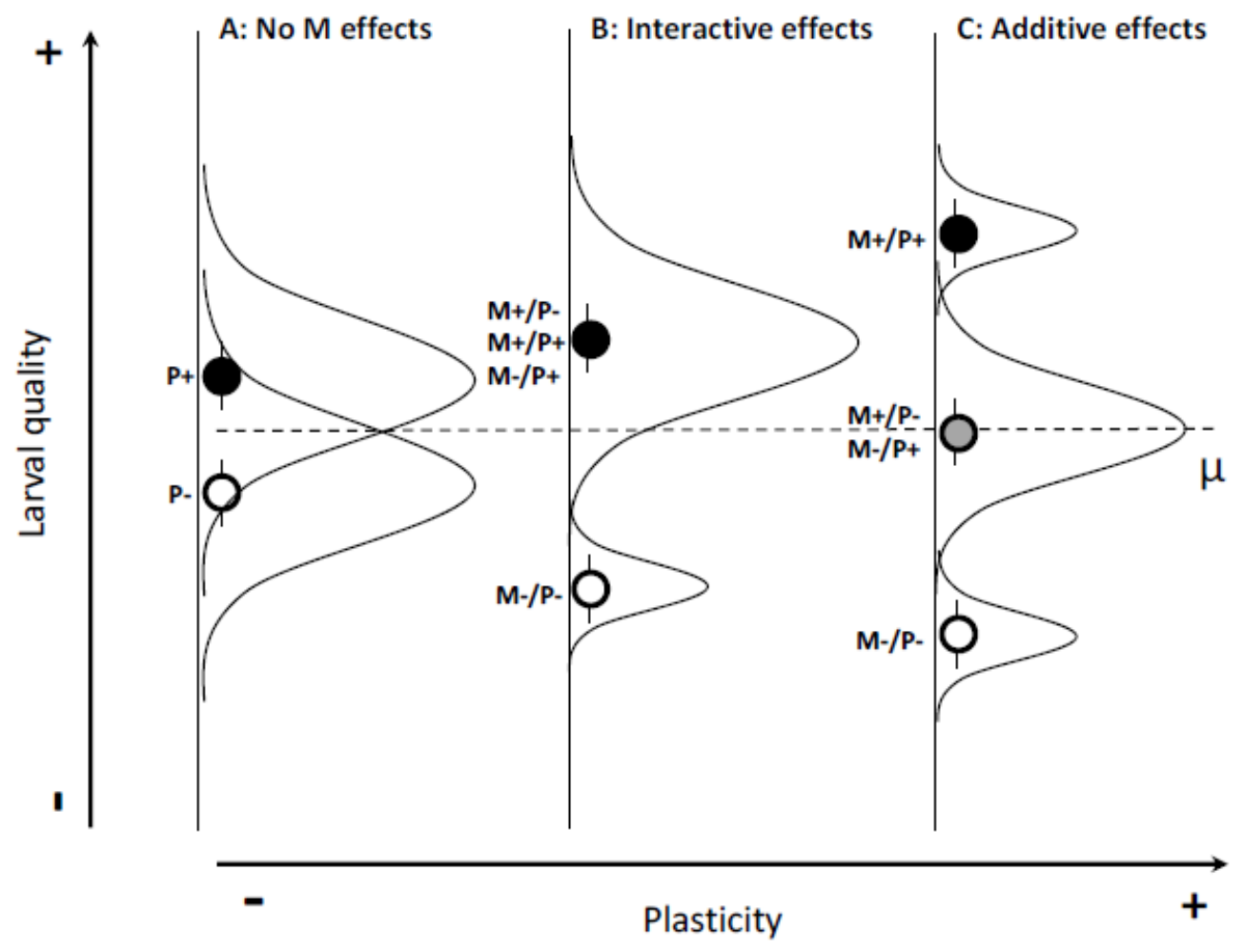

Figure 1. Conceptual joint effects of maternal $(\mathrm{M})$ and pelagic $(\mathrm{P})$ resource allocation on plastic larval traits of marine invertebrates, as predicted by factorial manipulative experiments. A: Low plasticity of larval traits responding only to pelagic effects, as expected for a strict planktotrophic larval development; B: Intermediate plasticity through canalization, with a marked conserved state over most of the environmental change, and an alternative less frequent state led by extreme conditions, in this particular case a poor phenotype owing to the interactive effects of low maternal and pelagic allocation; C: High plasticity through additive and independent effects of maternal and pelagic resources, likely shaping continuous trait variation over the whole range of environmental conditions. In this illustration, the magnitude of both effects is the same. Black, gray and white circles indicate average estimates of experimental treatments leading to high, intermediate and low larval quality, respectively. Areas below hypothetical normal curves represent relative frequencies of larval phenotypes. ' + ' and '-' signs indicate high and low resource supply.

In a first scenario, we advanced the strict planktotrophic condition, in which trait performance is solely dependent on pelagic resource allocation (Fig. 1A). In a second case, maternal allocation is added, thus increasing potential for plasticity, 
and interacts with pelagic allocation (Fig. 1B). Such a mechanism may underlie, for instance, shifts in trait states, from a widely observed standard condition to an alternative, less common state, under exceptionally favorable or unfavorable conditions. In this figure we depict a discrete low-quality phenotype resulting from the interaction of poor maternal and pelagic conditions. Very plastic traits would be the result of additive maternal and pelagic allocation (Fig. 1C) which, rather than aligned in discrete states, would be continuously distributed over their variation range.

In this study, we examined the regulation of recruitment components in the acorn barnacle C. bisinuatus (Pilsbry 1916), based on laboratory manipulations of the food supply provided to both parental populations (embryo allocation prone to eventual maternal effects) and their larvae (pelagic allocation). This chthamalid barnacle is the dominant species found on the high intertidal of rocky shores from the Brazilian northeast coast to Uruguay (Dando and Southward 1980; Young 1993). It is a filter feeding organism with a complex life cycle, which includes six naupliar planktotrophic stages and a final lecithotrophic stage, the cyprid. Endogenous reproductive rhythms in this species promote larval retention near the coast (Bueno et al. 2010; Kasten and Flores 2013), which was further supported by a field study in which specific daily patterns of larval release were correlated to settlement at a very local scale (Barbosa et al. 2016). Therefore, the maternal environment may reliably cue the trophic conditions that larvae may experience in the field and shape eventual strategies of maternal resource manipulation. All these characteristics make $C$. bisinuatus an adequate biological model to address the main questions of this study. We measured the median development time for cyprids (MDT, a proxy for development rate), the percentage 
of larvae reaching the cyprid stage (or cyprid yield, CY, a proxy for larval supply), and the cyprid size (CS, a proxy for early benthic performance) as a means to (i) understand how these recruitment components might be affected by maternal and larval resource limitation, (ii) identify fixed and plastic larval traits and (iii) advance ways in which plasticity may favour recruitment success.

\section{Methodology}

Experimental design - To investigate maternal and larval nutrition effects on Chthamalus bisinuatus larval traits, we conducted an experiment involving two factors: adult and larval food supply, both with two levels, high (HF) and low food (LF) concentration. In the laboratory, two different trials were performed during two different seasons: late summer and winter, so the temperatures set inside the rooms were selected to maintain the natural average temperature during these seasons; $26^{\circ} \mathrm{C}$ and $21^{\circ} \mathrm{C}$ respectively. Rock chips with dense barnacle cover (average 50\%) were collected from Calhetas beach (23 49' 54" S; 4531' 18" W),

São Paulo State, Brazil, on July 16 2014 for the winter temperature trial (low temperature from now on), and on March $20^{\text {th }} 2015$ for the late summer temperature trial (high temperature from now on). Chips (40 approximately, with an average barnacle opercular size of $2.26 \mathrm{~mm} \pm 0.7 \mathrm{~mm}$ ) were obtained over a rocky coastline of $100 \mathrm{~m}$ to include substantial environmental variation. Adult experimental populations and larvae were given either a high $\left(3 \times 10^{3}\right.$ cells $\left./ \mathrm{ml}\right)$ or a low ( $1 \times 10^{3}$ cells $/ \mathrm{ml}$ ) food supply, consisting of an even mixture of three microalgal species; two flagellates (Tetraselmis sp. and Isocrysis sp.) and a diatom (Thalassiosira sp.). Such concentrations were selected based on real phytoplankton 
concentration data sampled in the São Sebastião channel, close to the site where adult barnacles were collected.

After collection, experimental adult populations (rock chips) were assigned a feeding regime of low or high and kept in this food regime for at least $20 \mathrm{~d}$ (acclimation period). Barnacles were retained in 2 tanks (54 x $40 \times 20 \mathrm{~cm}$ ) and were given the microalgal mixture twice a day, for a period of one hour each time. Over the acclimation period, $C$. bisinuatus captive populations were submitted to two high tides during the day, by immersion in pre-filtered sea water $(3 \mu \mathrm{m})$ for 1 $\mathrm{h}$ when barnacles were fed, in an attempt to reproduce the semidiurnal tidal regime in the area. After the acclimation period, nauplii released by experimental populations were sampled. For that, all water from the tanks was first filtered through a $100 \mu \mathrm{m}$ mesh, and retain larvae, when present, were transferred with the aid of a glass pipette to pre-filtered $500 \mathrm{ml}$ glass beakers at a density of 0.5 nauplii/ml. A total of 12 beakers were prepared $(n=3$ for each of the four treatment combinations, i.e, adult and larvae HF, adult and larvae LF, adult HF and larvae LF, adult LF and larvae HF), and their position over bench space ensured spatial interspersion replicate beakers, thus avoiding the influence of any environmental gradients in the laboratory. Every other day, nauplii were fed the microalgal mixture at the tested concentrations and $90 \%$ of the water of the beakers was changed. After $10 \mathrm{~d}$, which was the time needed for chthamalid nauplii to start metamorphosing into cyprids, cultures were checked every other day for cyprid presence and, once observed, they were counted, extracted using a glass pipette and preserved in separate vials. Inspection of beakers ended when no new cyprids were observed, which corresponded to day 31 and day $20 \mathrm{~d}$ for low and high temperatures trials, respectively. 
Response variables - Three different larval parameters were separately quantified for each replicate beaker in each treatment combination. Cyprid yield (CY) was estimated as the percentage of nauplii that successfully developed to the cyprid stage. Median development time (MDT) was measured as the time (in days) by which $50 \%$ of all cyprids were obtained. Cyprid size (CS) was measured as the lateral carapace area $\left(\mu \mathrm{m}^{2}\right)$. Linear cyprid metrics were not adequate because of substantial variation in carapace shape. Measurements were obtained from magnified images (63x) using the software ImageJ (Schneider et al. 2012).

In order to compare the plasticity of CS in experimental treatments with natural variability, we measured cyprids sampled in nature from a different research project. Briefly, samples were sampled along the São Sebastião Channel, from January $21^{\text {st }}$ to March $28^{\text {th }} 2013$, at three sites adjacent to the shoreline: Praia

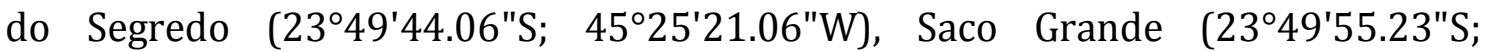
$45^{\circ} 25^{\prime} 43.57^{\prime \prime}$ ) and Itassucê (2349'56.77"S; 45²6'33.42"W). Three replicate samples, tens of meters apart, were obtained twice a week at each site, using 150 $\mu \mathrm{m}$ mesh nets. Cyprids were sorted and stored in a vertical freezer $\left(-20^{\circ} \mathrm{C}\right)$ until measurements.

Statistical analyses - All 3 response variables were analyzed using separate ANOVAs for the trial held at low temperature. In this case, maternal (high vs. low) and larval (high vs. low) food supply were considered fixed factors. CY and MDT were analyzed using 2 way ANOVAs with a sample size of 3 (i.e. the number of replicate beakers). For $\mathrm{CS}$, the unit of replication was the individual cyprid, and therefore we included a random factor in the analysis, 'beaker', nested within the interaction term. We ensured a balanced design by considering sample size as the minimum number of cyprids found in a beaker. Exceeding cyprids from remaining 
beakers were randomly removed from analyses. In all cases, the variances of data were homogeneous (Cochran's $C$-test, $p>0.05$ ). The SNK procedure was used for post-hoc comparisons when needed.

For the trial held at high temperature, no cyprids were obtained for treatments in which larvae were given the low food supply. We thus used Student's- $t$ tests to compare results within this trial and between equivalent experimental treatment combinations of the two trials. When necessary, data were log transformed to meet homoscedacity.

\section{Results}

\section{Low temperature trial}

Each larval trait responded differently to manipulations of maternal and larval food supply when the experiment was held at low temperature $\left(21^{\circ} \mathrm{C}\right.$; Table 1).

Table 1. Summary results of two-way ANOVAs comparing the response of larval traits to maternal and larval food supply in the low temperature trial $\left(21^{\circ} \mathrm{C}\right)$.

\begin{tabular}{|c|c|c|c|c|c|c|c|}
\hline & \multirow[b]{2}{*}{$\mathrm{df}$} & \multicolumn{2}{|c|}{ Cyprid yield } & \multicolumn{2}{|c|}{$\begin{array}{l}\text { Median Development } \\
\text { rate }\end{array}$} & \multicolumn{2}{|c|}{ Cyprid size } \\
\hline & & $\mathrm{F}$ & $p$ & $\mathrm{~F}$ & $p$ & $\mathrm{~F}$ & $p$ \\
\hline $\begin{array}{l}\text { Maternal food } \\
\text { supply: M }\end{array}$ & 1 & 0.39 & 0.549 & 45.56 & 0.001 & 8.93 & 0.017 \\
\hline $\begin{array}{l}\text { Larval food supply: } \\
\text { L }\end{array}$ & 1 & 12.49 & 0.007 & 45.56 & 0.001 & 9.16 & 0.016 \\
\hline$M \times L$ & 1 & 0.33 & 0.582 & 45.56 & 0.001 & 0.26 & 0.622 \\
\hline Beaker (M X L) & - & - & - & - & - & 1.51 & 0.167 \\
\hline Residual & 8 & & & & & & \\
\hline
\end{tabular}


At this trial, cyprid yield (CY) was only influenced by the amount of food larvae were offered during their development (Table 1), with no effects of maternal provision. CY nearly doubled from overall treatments of low to high larval food supply (13.3\% to $26.8 \%)$. Contrasts were maintained within maternal food conditions, with CY in better provisioned larvae around 2.4 and 1.7-fold higher in the low and the high maternal food supply treatments, respectively (Fig. 2A). 

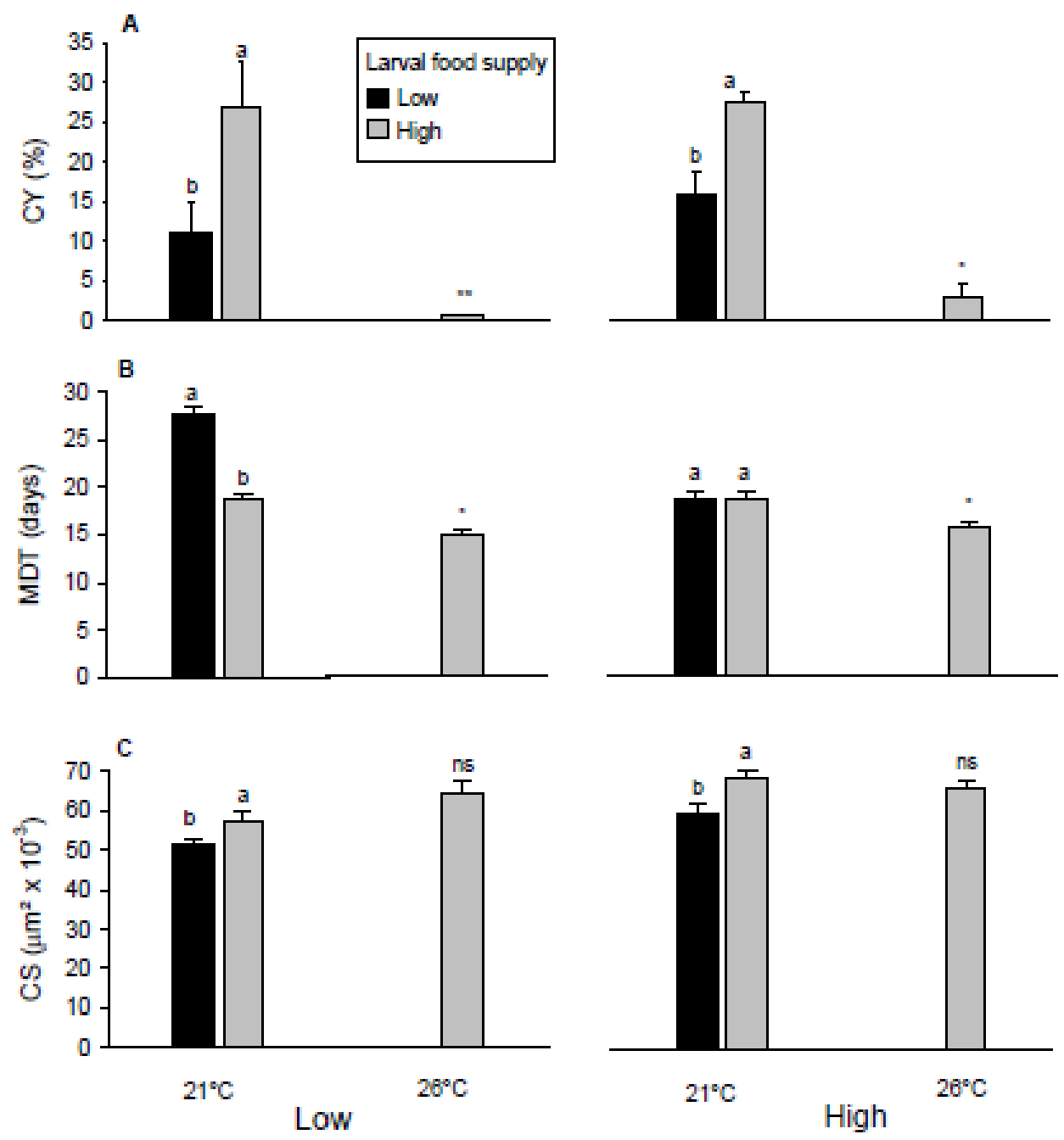

Maternal food supply

Figure 2. Response of larval traits to the combined effects of maternal (= embryonic) and pelagic ( = larval) resource supply for trials undertaken at different temperatures $\left(21^{\circ} \mathrm{C}\right.$ versus $26^{\circ} \mathrm{C}$ ). No data are presented for low larval food supply treatments in the $26^{\circ} \mathrm{C}$ trial because no larvae reached the cyprid stage. For the $21^{\circ} \mathrm{C}$ trial, different letters indicate statistical differences between levels of larval supply, within treatments of maternal supply. For the $26^{\circ} \mathrm{C}$ trial, scripts over bars indicate statistical significance of comparisons with the homologous treatments in the $21^{\circ} \mathrm{C}$ trial. ${ }^{* *} p<0.01{ }^{*} p<0.05$; ns: not significant. CY: cyprid yield; MDT median development time for the cyprid stage; CS: cyprid size.

Mean development time (MDT) was influenced by the interaction between maternal and larval food supply (Table 1). The time necessary for $50 \%$ of all cyprids to be observed was markedly constant, around 18 to 19 days for all treatment combinations, except when both mothers and larvae were fed a low food 
concentration. Under these later conditions MDT was much longer (27.7 days; Fig. 2B).

AS for MDT, both maternal and pelagic allocation played a role in the determination of cyprid size (CS). In this case, however, effects were additive, with independent control of resource allocation to mothers and larvae, as evidenced by the lack of significance of the interaction term (Table 1). Higher food supply allowed enhanced growth, with maternal and larval effects exerting quite similar effects (c.a. $13 \%$ to $14 \%$ size increase). Cyprid size was thus prone to extensive plasticity, from the smallest size observed when both mothers and larvae were supplied with low food rations to the largest size observed when food supply was the higher at those two stages (Fig. 2C).

\section{High temperature trial}

Under high temperature conditions $\left(26^{\circ} \mathrm{C}\right)$, nauplii succeeded to metamorphose to the cyprid stage only when they were given a high food supply (Fig. 3A); no cyprids were observed under low larval food supply, irrespective of maternal resource allocation. Therefore, further comparisons are restricted to treatments in which larval food supply was high.

Maternal food allocation played no apparent role for the much fewer surviving larvae in the high temperature trial. CY was very low, not surpassing $3 \%$ regardless of whether or not maternal populations were poorly or well-fed $(t=$ 0.707, $p=0.518$; Fig. 2A). This further supports no carry-over effects from embryonic allocation on larval survival. MDT was also very consistent, varying only from an average of 14.7 to 15.3 days $(t=0.286, p>0.05$; Fig. $2 \mathrm{~B})$. This result reinforces the notion that the time for larval development is a very consistent 
variable for a given temperature. Differences between cyprid sizes were also very slight and not significant $(t=0.455, p=0.655$; Fig. $2 \mathrm{C})$.

\section{Comparisons between temperature trials}

Comparisons between the two temperature trials were restricted to equivalent treatment combinations (high larval resource allocation). CY was heavily depressed in the high temperature trial, for both maternal food conditions (low: $t=4.38 ; p=0.011$; high: $t=13.02 ; p<0.01$; Fig. 2A). MDT was also influenced by temperature, with a substantial and significant decrease in warmer conditions for both low $(t=3.35 ; p<0.05)$ and high $(t=4.24 ; p<0.05)$ maternal provision, i.e. a faster development rate as expected (Fig. 2B). CS was unaffected by temperature (low: $t=0.594$; high: $t=0.79, \quad p>0.05$ for the two cases, Fig. 2C).

Plasticity in cyprid size - a comparison between wild and captive individuals

Our results show that laboratory manipulations of food supply for both breeding barnacle populations and their larvae are capable to produce the full range of cyprid size variation that may be encountered in the São Sebastião Channel (Fig. 3). This result strengthens the argument for strong additive and independent effects of resource provisioning for mothers (a carry-over effect up, at least, to the cyprid stage) and pelagic larvae. 


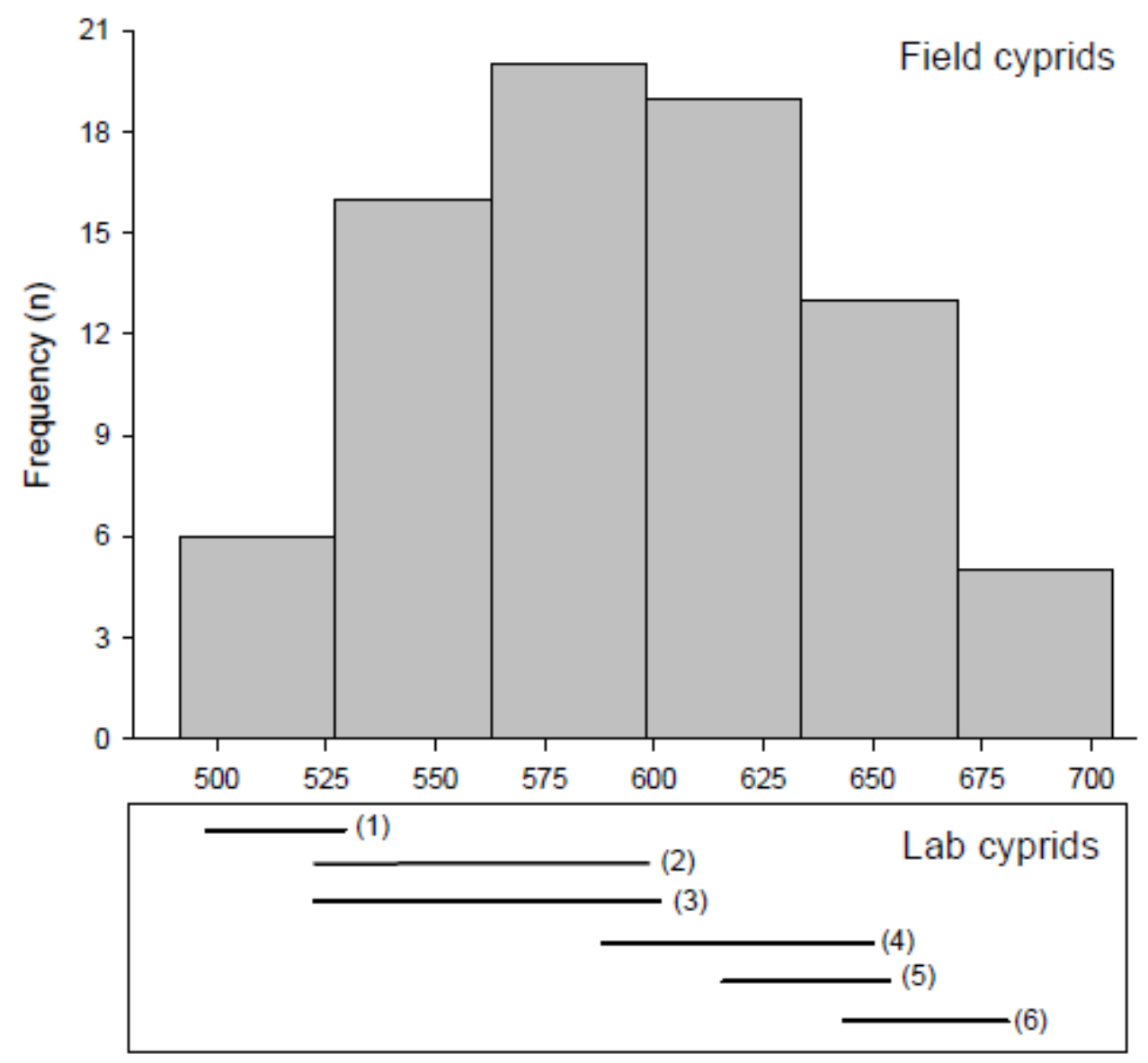

Carapace area $\left(\mu \mathrm{m}^{2} .10^{-2}\right)$

Figure 3. Size frequency distribution of Chthamalus spp cyprid stages collected in the field, and \pm 1 SE size ranges of cyprids obtained from the different experimental treatments manipulating maternal (M) and larval (L) allocation. (1) M - L - , 21 ${ }^{\circ} \mathrm{C}$; (2) M + L -, 21 ${ }^{\circ} \mathrm{C}$; (3) $\mathrm{M}-\mathrm{L}+, 21^{\circ} \mathrm{C}$; (4) M - L +, $26^{\circ} \mathrm{C}$; (5) $\mathrm{M}+\mathrm{L}+, 26^{\circ} \mathrm{C}$; (6) $\mathrm{M}+\mathrm{L}+, 21^{\circ} \mathrm{C}$.

\section{Discussion}

This study highlights the notion that so-called 'planktotrophic' larvae may actually largely rely on energetic resources allocated during embryogenesis throughout their pelagic existence, and that trophic resources at different ontogenetic stages interact in complex and specific ways, generating substantial plasticity of larval traits, which directly affect different recruitment components. 
The three traits examined in this contribution, i.e. cyprid yield (= larval survival), median development time (= larval development rate) and cyprid size (which is known to correlate to the quality of settling individuals) covered the range of mechanisms we conceived for the control of larval traits by joint effects of maternal and larval resource allocation (Fig. 1).

As fully planktotrophic larvae, survival to the cyprid stage was found to be solely dependent on pelagic resources to larvae, which in nature would translate to no effects on the larval supply to adult populations. Carry-over effects from maternal resource allocation through embryogenesis was however quite important in the control of development rate and size of larvae at the settling stage. Our results corroborate that the pace of larval development is a very robust trait, remaining relatively unaltered by substantial environmental change, except for temperature. Even so, development rate responds linearly and positively to temperature change (Scheltema and Williams 1982; Anil et al. 2001), so that meaningful change from expected values can suggest an alternative development pathway. Here we show that persistence of inadequate trophic conditions through embryogenesis and larval pelagic duration does not translate to a gradual change of temperature-specific development rate, but to an alternative discrete state, leading to low quality larvae (as showed in the analyses of cyprid size). Therefore, development rate may assume discrete states through interactive effects of maternal and larval food supply. Finally, additive effects were clear in the determination of cyprid size, which very probably correlates to early benthic performance of juvenile stages (Pechenik et al. 1998; Moran and Emlet 2001). Interestingly, the magnitude of independent effects of maternal and pelagic inputs was virtually the same. In other words, cyprid size could be predicted by the 
overall trophic budget, no matter if this was balanced or not over embryogenesis and larval development. Also, it is noteworthy the fact that rather simple manipulations of food supply in the lab, with only two levels of main factors, was sufficient to replicate the full range of plasticity observed in the field. Further laboratory trials are pending to verify how far can trophic resources push cyprid size under simultaneous provision of adequate concentration and quality of phytoplankton cells.

Past studies have already demonstrated how larval food supply is an important factor influencing both larval survival and, consequently, recruitment success (Thorson 1950; Olson and Olson 1989; Pfeiffer-Hoyt and Mcmanus 2005). Considering the patchy distribution of phytoplankton in the water column, larvae face high probabilities of failing to encounter enough food for their development, enhancing mortality due to a high sensitivity to starvation (Barnes and Barnes 1959; Lang and Marcy 1982) and, thus, failing to metamorphose into late larval stages which are responsible for settlement. In addition, increased temperature elevates the metabolic rate of crustacean larvae (Anger and Dawris 1981; Anil et al. 2001) and, when these organisms fail to encounter minimum levels of food at such temperatures, mortality rate can become even higher. Nauplii reared under lower temperatures $\left(21^{\circ} \mathrm{C}\right)$ succeeded to metamorphose into cyprid in a much higher percentage than the nauplii reared under higher temperatures $\left(26^{\circ} \mathrm{C}\right)$. Also, when kept under $21^{\circ} \mathrm{C}$, those nauplii fed a higher food concentration metamorphosed to cyprid in higher numbers than those reared with low food supply, regardless the amount of food the maternal population which produced them were fed. Such findings stress the impact of larval experience on the larval supply outcome. A low 
recruitment success may be related to the conditions larvae develop within and how that environment impact survival rate.

Survival rate is also related to the amount of time larvae spend in the plankton and the predation risk they undergo while in development. Median development time (MDT), was influenced by temperature and the interaction of both maternal and larval food supply. It is well established that increases in temperature are positively related to barnacles larval development (Palmer and Strathmann 1981; Anil and Kurian 1996; Pfeiffer-Hoyt and Mcmanus 2005), probably because under higher temperatures, larval feeding capacity is enhanced (Scheltema and Williams 1982; Bolton and Havenhand 2005). Our results demonstrate the same pattern. In a first analysis comparing MDT of larvae reared under $21^{\circ} \mathrm{C}$ and $26^{\circ} \mathrm{C}$, it was clear that under lower temperatures larvae developed significantly slower than those reared under $26^{\circ} \mathrm{C}$. Even though a shorter development time means lower predation risk (Thorson 1950), and therefore, lower risk of mortality, one could expect to observe more cyprids from higher temperature treatments. But that was not the case, our results showed that mortality might be caused by elevated temperatures, so a shorter time in the plankton does not guarantee higher larval survival and thus, higher larval supply.

When larvae were reared under lower temperatures, both maternal and larval supply had an impact on MDT. Under lower temperatures, nauplii present an almost fixed MDT (around 18 days), considering that at least mothers or larvae face high food concentrations at some point. But, when poorly fed mothers produced larvae that also developed under poor food concentrations, nauplii delayed their MDT to approximately 27 days. It seems plausible to assume that poorly fed mothers invest less energy to nauplii, which can overcome such 
deficiency when facing high food availability; if not, such deficiency cannot be surpassed and nauplii develops in a slower rate. Mothers experiencing high food concentrations seem to invest enough energy to nauplii that, even under low food supply, can develop at a constant rate. Although larval nutrition seems to have a greater impact on the MDT of $C$. bisinuatus nauplii, maternal nutrition still impacts this trait through a carry-over effect, that can only be perceived in low food conditions for both adults and larvae.

Cyprid size (CS), a proxy of larval quality, was influenced by both maternal and larval nutrition, but not the interaction of these factors, neither by temperature. When mothers and larvae were reared with high food levels, larger cyprids were produced, while the smallest cyprids observed were a product of mother and nauplii fed a low food supply, regardless of the temperature under which they were reared. Such results indicate a possible additive effect resulted from the maternal and larval feeding experience. Well fed mothers seem to have the capacity to produce larger larvae that, in the case of encountering high food concentrations as well, will grow to bigger sizes. Although the initial larval size was not measured in this study, one can observe that cyprids which originated from well fed mothers always reached bigger sizes then those produced by poorly fed mothers. The size the cyprid can reach depended also on the feeding experience of nauplii before metamorphosis. Also, the size reached by cyprids reared in the laboratory are among the sizes observed in cyprids sampled from the natural environment, indicating that the natural variation observed might be a response to both maternal and pelagic effects regarding food concentration.

São Sebastião Channel, site where $C$. bisinuatus populations were sampled from, is known to be a oligotrophic region, with some increases of phytoplankton 
concentrations during upwelling events in the summer or due to vertical mixing events when cold fronts are present in the winter (Ciotti et al. 2010), so food availability for both maternal populations and larvae are low during most part of the year. When living under such conditions, $C$. bisinuatus seem to have developed a reproductive strategy that guarantees its own fitness or the recently spawned larvae fitness, depending on the level of stress faced (Freuchet et al. 2015). The effects of nutritional stress faced by mothers and nauplii can be carried over until the late larval stage, as seen in this study, and might have direct implications for recruitment success. Time spent in the plankton and cyprid quality are components of recruitment that are influenced by the maternal and larval experience, while larval supply depends mostly on larval experience in the plankton; so the probabilities of a successful recruitment for this tropical barnacle are affected by conditions experienced long before the settlement phase. Once more our study agrees with other authors realizing that a successful recruitment starts long before the late larval phase; adult benthic phase environmental conditions will influence future larval generations and, consequently the maintenance of those populations. 


\section{Bibliography}

Allen R, Buckley Y, Marshall D (2008) Offspring Size Plasticity in Response to Intraspecific Competition: An Adaptive Maternal Effect across Life-History Stages. Am Nat 171:225-237. doi: 10.1086/524952

Anger K (2001) The biology of decapod crustacean larvae.

Anger K, Dawris R (1981) Influence of starvation on the larval development of Hyras araneus (Decapoda, Majidae). Helgolander Meeresuntersuchungen 34:287-311.

Anil A, Desai D, Khandeparker L (2001) Larval development and metamorphosis in Balanus amphitrite Darwin (Cirripedia; Thoracica): significance of food concentration, temperature and nucleic acids. J Exp Mar Bio Ecol 263:125-141. doi: 10.1016/S0022-0981(01)00280-5

Anil A, Kurian J (1996) Influence of food concentration, temperature and salinity on the larval development of Balanus amphitrite. Mar Biol 127:115-124. doi: 10.1007/BF00993651

Barbosa A, Gomes C, Pereira G, et al (2016) Local biological drivers, not remote forcing, predict settlement rate to a subtropical barnacle population. Mar Ecol Prog Ser. doi: 10.3354/meps11589

Barnes H, Barnes M (1959) A comparison of the annual growth patterns of Balanus balanoides (L.) with particular reference to the effect of food and temperature. Oikos 10:1-18.

Basch L, Pearse J (1995) Consequences of larval feeding environment for settlement and metamorphosis of a temperate echinoderm. Oceanol acta 19:273-285.

Bay L, Buechler K, Gagliano M, Caley M (2006) Intraspecific variation in the pelagic larval duration of tropical reef fishes. J Fish Biol 68:1206-1214. doi: 10.1111/j.0022-1112.2006.01016.x

Berkeley S, Chapman C, Sogard S (2004) Maternal Age as a Determinant of Larval Growth and Survival in a Marine Fish , Sebastes melanops. Ecology 85:12581264.

Bernardo J (1996) Maternal effects in animal ecology. Am Zool 36:83-105.

Bertness M, Gaines S, Stephens E, Yund P (1992) Components of recruitment in populations of the acorn barnacle Semibalanus balanoides (Linnaeus). J Exp Mar Bio Ecol 156:199-215. doi: 10.1016/0022-0981(92)90246-7

Bertram D, Strathmann R (1998) Effects of maternal and larval nutrition on growth and form of planktotrophic larvae. Ecology 79:315-327.

Bingham B (1992) Life Histories in an Epifaunal Community: Coupling of Adult and Larval Processes. Ecology 73:2244-2259.

Boidron-Metairon I (1988) Morphological plasticity in laboratory-reared echinoplutei of Dendraster excentricus (Eschscholtz) and Lytechinus variegatus (Lamarck) in response to food conditions. J Exp Mar Bio Ecol 119:31-41. doi: 10.1016/00220981(88)90150-5

Bolton T, Havenhand J (2005) Physiological acclimation to decreased water temperature and the relative importance of water viscosity in determining the feeding performance of larvae of a serpulid polychaete. J Plankton Res 27:875879. doi: 10.1093/plankt/fbi060

Botello G, Krug P (2006) 'Desperate larvae' revisited: age, energy and experience affect sensitivity to settlement cues in larvae of the gastropod Alderia sp. Mar Ecol Prog Ser 312:149-159. doi: 10.3354/meps312149

Bueno M, Moser G, Tocci B, Flores A (2010) Retention-favorable timing of propagule release in barnacles and periwinkles. Mar Ecol Prog Ser 414:155-165. doi: 


\subsection{4/meps08715}

Caley M, Carr M, Hixon M, et al (1996) Recruitment and the local dynamics of open marine populations. Annu Rev Ecol Evol Syst 27:477-500. doi: 10.1146/annurev.ecolsys.27.1.477

Ciotti Á, Garcia C, Jorge D (2010) Temporal and meridional variability of Satelliteestimates of surface chlorophyll concentration over the Brazilian continental shelf. Pan-American J ... 5:236-253.

Cushing D (1990) Plankton production and year-class strength in fish populations: an update of the match/mismatch hypothesis. Adv Mar Biol 249-293.

Dando P, Southward A (1980) A new species of Chthamalus (Crustacea: Cirripedia) characterized by enzyme electrophoresis and shell morphology: with a revision of other species of Chthamalus from the western shores of the atlantic ocean. J Mar Biol Assoc United Kingdom 60:787. doi: 10.1017/S0025315400040455

Diss A, Kunkel J, Montgomery M, Leonard D (1996) Effects of maternal nutrition and egg provisioning on parameters of larval hatch, survival and dispersal in the gypsy moth, Lymantria dispar L. Oecologia 106:470-477. doi: 10.1007/BF00329704

Dixon P, Milicich M, Sugihara G (1999) Episodic Fluctuations in Larval Supply. Science (80- ) 283:1528-1530. doi: 10.1126/science.283.5407.1528

Fenaux L, Strathmann M, Strathmann R (1994) Five tests of food-limited growth of larvae in coastal waters by comparisons of rates of development and form of echinoplutei. Limnol Oceanogr 39:84-98. doi: 10.4319/lo.1994.39.1.0084

Fox C, Thakar M, Mousseau T (1997) The Evolutionary Genetics of an Adaptive Maternal Effect : Egg Size Plasticity in a Seed Beetle. 149:149-163.

Freuchet F, Tremblay R, Flores A (2015) Interacting environmental stressors modulate reproductive output and larval performance in a tropical intertidal barnacle. Mar Ecol Prog Ser 532:161-175. doi: 10.3354/meps11377

Gagliano M, McCormick M (2007) Maternal condition influences phenotypic selection on offspring. J Anim Ecol 76:174-182. doi: 10.1111/j.1365-2656.2006.01187.x

Gaines S, Brown S, Roughgarden J (1985) Spatial variation in larval concentrations as a cause of spatial variation in settlement for the barnacle, Balanus glandula. Oecologia 67:267-272. doi: 10.1007/BF00384297

Gaines S, Roughgarden J (1985) Larval settlement rate: A leading determinant of structure in an ecological community of the marine intertidal zone. Proc Natl Acad Sci U S A 82:3707-11.

Hughes T, Baird A, Dinsdale E, et al (2000) Supply-Side Ecology Works Both Ways: The Link between Benthic Adults, Fecundity, and Larval Recruits. Ecology 81:2241-2249. doi: 10.2307/177111

Jarrett J (2003) Seasonal Variation in Larval Condition and Postsettlement Performance of the Barnacle Semibalanus Balanoides. Ecology 84:384-390. doi: 10.1890/00129658(2003)084[0384:SVILCA]2.0.CO;2

Jarrett J, Pechenik J (1997) Temporal Variation in Cyprid Quality and Juvenile Growth Capacity for an Intertidal Barnacle. Ecology 78:1262-1265. doi: 10.1890/00129658(1997)078[1262:TVICQA]2.0.CO;2

Jonsson P, Berntsson K, Larsson A (2004) Linking Larval Supply To Recruitment: Flow-Mediated Control of Initial Adhesion of Barnacle Larvae. Ecology 85:28502859. doi: 10.1890/03-0565

Kasten P, Flores A (2013) Disruption of endogenous tidal rhythms of larval release linked to food supply and heat stress in an intertidal barnacle. Mar Ecol Prog Ser 472:185-198. doi: 10.3354/meps10005

Krug P (2001) Bet-hedging dispersal strategy of a specialist marine herbivore: A 
settlement dimorphism among sibling larvae of Alderia modesta. Mar Ecol Prog Ser 213:177-192. doi: 10.3354/meps213177

Lang W, Marcy M (1982) SOME EFFECTS OF EARLY STARVATION ON THE SURVIVAL IMPROVISUS. J Exp Mar Bio Ecol 60:63-70.

Letcher B, Rice J, Crowder L, Rose K (1996) Variability in survival of larval fish: disentangling components with a generalized individual-based model. Can J Fish Aquat Sci 53:787-801. doi: 10.1139/f95-241

Marshall D, Bolton T, Keough M (2003) Offspring size affects the post-metamorphic performance of a colonial marine invertebrate. Ecology 84:3131-3137.

Marshall J, Uller T (2007) When is a maternal effect adaptive? Oikos 116:1957-1963. doi: 10.1111/j.2007.0030-1299.16203.x

Miller S, Morgan S (2013) Phenotypic plasticity in larval swimming behavior in estuarine and coastal crab populations. J Exp Mar Bio Ecol 449:45-50. doi: 10.1016/j.jembe.2013.08.013

Moran A, Emlet R (2001) Offspring Size and Performance in Variable Environments: Field Studies on a Marine Snail. Ecology 82:1597-1612. doi: 10.2307/2679803

Olson R, Olson M (1989) Food Limitation of Planktotrophic Marine Invertebrate Larvae: Does it Control Recruitment Success? Annu. Rev. Ecol. Syst.

Palmer A, Strathmann R (1981) Scale of dispersal in varying environments and its implications for life histories of marine invertebrates. Oecologia 48:308-318.

Pechenik J (1990) Delayed metamorphosis by larvae of benthic marine invertebrates : Does it occur? Is there a price to pay? Ophelia 32:63-94.

Pechenik J (2006) Larval experience and latent effects--metamorphosis is not a new beginning. Integr Comp Biol 46:323-333. doi: 10.1093/icb/icj028

Pechenik J, Estrella M, Hammer K (1996) Food limitation stimulates metamorphosis of competent larvae and alters postmetamorphic growth rate in the marine prosobranch gastropod Crepidula fornicata. Mar Biol 127:267-275. doi: 10.1007/BF00942112

Pechenik J, Gleason T, Daniels D, Champlin D (2001) Influence of larval exposure to salinity and cadmium stress on juvenile performance of two marine invertebrates (Capitella sp. I and Crepidula fornicata). J Exp Mar Bio Ecol 264:101-114. doi: 10.1016/S0022-0981(01)00313-6

Pechenik J, Tyrell A (2015) Larval diet alters larval growth rates and post-metamorphic performance in the marine gastropod Crepidula fornicata. Mar Biol. doi: $10.1007 / \mathrm{s} 00227-015-2696-7$

Pechenik J, Wendt D, Jarrett J (1998) Metamorphosis Is Not a New Beginning Larval experience influences juvenile performance. Bioscience 48:901-910.

Pepin P, Myers R (1991) Significance of Egg and Larval Size to Recruitment Variability of Temperate Marine Fish. Can J Fish Aquat Sci 48:1820-1828. doi: 10.1139/f91-215

Pfeiffer-Hoyt A, Mcmanus M (2005) Modeling the effects of environmental variability on Balanus glandula larval development. J Plankton Res 27:1211-1228. doi: 10.1093/plankt/fbi089

Phillips N (2006) Natural variability in size and condition at settlement of 3 species of marine invertebrates. Integr Comp Biol 46:598-604. doi: 10.1093/icb/ic1008

Phillips N (2002) Effects of nutrition-mediated larval condition on juvenile performance in a marine mussel. Ecology 83:2562-2574.

Pilsbry H (1916) The sessile barnacles (cirripedia) contained in the collections of the U.S. National museum; including a monograph oh the american species.

Pineda J (1994) Spatial and temporal patterns in barnacle settlement rate along a 
Southern California rocky shore. Mar Ecol Prog Ser 107:125-138. doi: 10.3354/meps 107125

Poorbagher H, Lamare M, Barker M (2010) The relative importance of parental nutrition and population versus larval diet on development and phenotypic plasticity of Sclerasterias mollis larvae. J Mar Biol Assoc United Kingdom 90:527-536. doi: 10.1017/S0025315409990907

Raimondi P (1990) Patterns, mechanisms, consequences of variability in settlement and recruitment of an intertidal barnacle. Ecol Monogr 60:283-309.

Reznick D, Callahan H, Llauredo R (1996) Maternal Effects on Offspring Quality in Poeciliid Fishes. Am Zool 36:147-156.

Reznick D, Yang A (1993) The influence of fluctuating resources on life history patterns of allocation and plasticity in female guppies. Ecology 74:2011-2019.

Roughgarden J, Gaines S, Possingham H (1988) Recruitment dynamics in complex life cycles. Science (80- ) 241:1460 - 1466.

Scheltema R, Williams I (1982) Significance of temperature to larval survivial and lenght of development in Balanus eburneus (Crustacea: Cirripedia). Mar Ecol Prog Ser 9:43-49.

Schneider A, Rasband W, Eliceiri K (2012) NIH Image to ImageJ: 25 years of image analysis. Nat Methods 9:671-675.

Searcy S, Sponaugle S (2000) Variable larval growth in a coral reef fish. Mar Ecol Ser 206:213-226. doi: 10.3354/meps206213

Shima J, Findlay A (2002) Pelagic larval growth rate impacts benthic settlement and survival of a temperate reef fish. Mar Ecol Prog Ser 235:303-309. doi: $10.3354 /$ meps 235303

Shima J, Swearer S (2009) Larval quality is shaped by matrix effects: implications for connectivity in a marine metapopulation. Ecology 90:1255-1267.

Starr M, Himmelman J, Therriault J (1991) Coupling of nauplii release in barnacles with phytoplankton blooms: A parallel strategy to that of spawning in urchins and mussels. J Plankton Res 13:561-571. doi: 10.1093/plankt/13.3.561

Strathmann R (1985) Feeding and Nonfeeding Larval Development and Life-History Evolution in Marine Invertebrates. Annu Rev Ecol Syst 16:339-361. doi: 10.1146/annurev.ecolsys.16.1.339

Thiyagarajan V, Harder T, Qian P (2002) Relationship between cyprid energy reserves and metamorphosis in the barnacle Balanus amphitrite Darwin (Cirripedia; Thoracica). J Exp Mar Bio Ecol 280:79-93. doi: 10.1016/S0022-0981(02)00415-X

Thiyagarajan V, Harder T, Qian P (2003) Effects of TAG/DNA ratio and age of cyprids on post-metamorphic growth and survival in the barnacle Balanus amphitrite. $\mathrm{J}$ Mar Biol Assoc UK 83:83-88.

Thorson G (1950) Reproductive and larval ecology of marine bottom invertebrates. Biol Rev 25:1-45. doi: 10.1111/j.1469-185X.1950.tb00585.x

Todd C (1998) Larval supply and recruitment of benthic invertebrates : do larvae always disperse as much as we believe ? Hydrobiologia 375/376:1-21.

Toonen R, Pawlik J (2001) Settlement of the gregarious tube worm Hydroides dianthus (Polychaeta: Serpulidae). II. Testing the desperate larva hypothesis. Mar Ecol Prog Ser 224:115-131. doi: 10.3354/meps224115

Toupoint N, Gilmore-Solomon L, Bourque F, et al (2012) Match/mismatch between the Mytilus edulis larval supply and seston quality: effect on recruitment. Ecology 93:1922-1934. doi: 10.1890/11-1292.1

Vance R (1973) On reproductive strategies in marine benthic invertebrates. Am Nat 107:339-352. 
Voss R, Clemmesen C, Baumann H, Hinrichsen H (2006) Baltic sprat larvae: Coupling food availability, larval condition and survival. Mar Ecol Prog Ser 308:243-254. doi: 10.3354/meps308243

Wilbur H (1980) Complex Life Cycles. Annu Rev Ecol Syst 11:67-93. doi: 10.1146/annurev.es.11.110180.000435

Young P (1993) The Verrucomorpha Chthamaloidea from the Brazilian coast (Crustacea: Cirripedia). Rev Bras Biol 53:255-267. 


\section{GENERAL CONCLUSIONS}

The role of environmental and biological factors acting on sessile marine organisms life cycle has been studied by several authors and in this thesis we demonstrated the great impact that food supply enrolls on different stages of chthamalid barnacles life cycle. Through three different approaches, we were able to state that variations on food supply can guide patterns of abundance of this organisms, modify reproductive traits during different seasons and also influence the quality of larvae, being them recently spawned or late larval stages.

Much of what is known regarding factors influencing chthamalid barnacles distribution are based on temperate species, from both Europe and North America. Abiotic factors such as desiccation, temperature and wave exposure and also biotic factors like reproduction, settlement behavior and recruitment have been stressed as main agents affecting chthamalid populations. With this on mind, we conducted an exploratory work attempting to link which environmental factors could be more important to these barnacles distribution along a large extension of the subtropical coast of Southeast region in Brazil. Our results point to the importance of chlorophyll- $a$, a proxy of phytoplankton biomass, thus a source of food supply for filter feeding animals, wave exposure and distance from large urban areas for both the abundance and size of chthamalid barnacles.

In marine ecology, when nutrients and/or primary producers concentration have an impact on higher level populations its common to use the term "bottomup" control (Carpenter 1988; Persson et al. 1995) and this processes seems to be part of what controls chthamalid barnacles distribution along the surveyed shore line. We observed that denser populations and larger animals were correlated to 
sites with higher chlorophyll-a concentrations. Higher concentration of phytoplankton in the water column results in more food for filter feeding animals like chthamalid barnacles, thus they can gather more energy for growth and reproduction. Also, higher food supply in the plankton might benefit larvae feeding while developing and this could result in higher recruitment rates, as larvae will settle and metamorphose into the juvenile with a higher energetic reserve.

Interestingly, we also observed a negative correlation between barnacle abundance and distance to large urban areas, indicating that denser populations are located closer to these sites. The large urban areas selected for this study have more than 20.000 inhabitants, which results in great water pollution due to sewage discharge on near shore waters. Higher levels of sewage discharge results in eutrophication of the water column, which in turn, can elevate primary producers growth. But our results did not show any correlation between distance to large urban areas and chlorophyll- $a$, as expected by the former rational. This raises the question if phytoplankton is the main food source for this filter feeding animals. Sewage discharge is another source of organic and inorganic matter in the near shore waters, and it can be found dissolved or not in the water column. A few studies have shown that marine invertebrates are able to assimilate dissolved organic matter (Wotton 1988; Wendt and Johnson 2006) and this might explain the correlation mentioned above, although we could not measure dissolved organic matter in this study.

But not only food supply showed influence on chthamalid traits. Wave exposure was negatively correlated to barnacle average size, indicating that populations on more wave-swept sites are formed by smaller animals. This could be a consequence of higher dislodgment of larger animals by wave action on higher 
midshore sites, being the populations there present constituted by younger animals, and thus, smaller. Also, wave-swept sites are prone to receive more larvae due to the higher water action on them, so one could expect to observe a higher number of small organisms on such sites. But this was not the case, our results show a positive correlation between barnacles average size and abundance, indicating that denser populations are composed by larger animals. This follows an opposite pattern from what has already been observed for other species. Bertness (1989) for example observed that high recruitment of Semibalanus balanoides leads to high mortality rate due to density-dependent processes, provoking the death of a large part of juveniles before they reproduce and resulting in smaller individuals in dense populations. To explain the observed correlation, we hypothesize that denser populations could alter the local surrounding environment of adults, beneficiating the growth potential, as demonstrated by Bertness and colleagues (Bertness et al. 1998).

Along the Brazilian coast is possible to observe a gradient of phytoplankton biomass from north to south, wherein the southern most regions present higher average values of chlorophyll- $a$ concentrations. This concentrations changes throughout the year, and at our study region summer is the season with the lowest chlorophyll- $a$ values and winter the season with the highest values (Ciotti et al. 2010). Being present from the Uruguayan coast until the northeast coast of Brazil, chthamalid barnacles experiences such contrasting conditions and, thus, we hypothesized if such changes in food supply could promote changes in fecundity and larval quality through maternal effects. Much is known about maternal energetic provisioning to lecithotrophic larvae because of the logic necessity of endogenous energy for survival until metamorphosis. In our study we were able to 
show that there is also differential maternal provisioning to planktotrophic larvae related to food supply for maternal populations.

First (chapter 2), we detected seasonal differences in fecundity and recently spawned larvae quality of chthamalid barnacles. Although no clear north-south pattern of chlorophyll- $a$ and particulate organic carbon could be observed during the summer months, during the winter months such pattern arose and concentrations of both food supply proxies were higher during this last season. It is interesting to see that chthamalid barnacles produced more larvae during summer months, period when food supply for both mothers and larvae is low compared to winter months, when barnacles produced less larvae. But the larvae produced during summer had lower quality then those produced during the winter, indicating a possible trade-off between number and quality of larvae regarding food supply. The higher quality larvae produced in lower numbers during the winter could result in a recruitment rate proportionally higher than the recruitment rates during the summer, as the larvae spawned during winter have a higher survival potential and will probably encounter greater amounts of food supply during this season, enhancing its survival rates and energy assimilation for reaching competence.

Furthermore, we are able to demonstrate that food availability for both maternal populations and larvae have an impact on cyprids traits reared under different temperatures (chapter 3). Time spent in the plankton depends on the amount of energy nauplii gather during its development and also temperature, being the development of crustaceans larvae faster under higher temperatures. Larvae reared under higher temperatures developed faster than those reared under lower temperatures in our study. In a scenario where temperature is high, 
during the summer for example, larvae encountering higher amounts of food, which can occasionally happen at our region (Guenther et al. 2008), could developed into the cyprid stage much faster than under other conditions, possibly promoting a self recruitment pattern. Nevertheless, under lower temperatures, cyprids originated from well fed mother and nauplii were obtained faster than those originated by poorly fed mothers and nauplii. Also, cyprids final size was also influenced by maternal and nauplii feeding history, but no interaction between this two factors could be observed in our survey. The amount of nauplii surviving until metamorphose to cyprid depends mostly on the temperature they are reared and the amount of food provided to them, being the maternal food supply not important for this trait. Such plasticity observed on cyprids traits could have an adaptive value, as such variation on this late larval stage can promote higher survival rates for the future early juvenile. One could expect to observe higher plasticity related to food supply on tropical/subtropical regions, as these areas normally present mesotrophic or even oligotrophic conditions in the water column at large scales. Mothers that are able to perceive higher food concentrations could be able to assimilate and allocate more energy for its progeny, elevating their quality. On the other hand, when food availability is poor, maternal population might not be able to allocate enough energy for its progeny, as it might use whatever is available for its own maintenance, resulting in lower quality larvae, and thus, higher plasticity can arise from differences in food supply.

Working with chthamalid barnacles as a biological model provided us better understanding of how local oceanographic conditions impact different life phases of sessile benthic invertebrates. As presented in this thesis, the experience animals experience in one life phase can alter the following one, which makes it crucial to 
better understand what are the main factors of influence for this animals reproductive strategies. Our results stresses the importance of food supply for filter feeding animals in subtropical conditions and further studies should be conducted to test weather phytoplankton is indeed the main food source for this animals on oligotrophic region like the one in this study. Effort should be made regarding other possible factors that could explain variation on reproductive potential of chthamalid barnacles along a subtropical coast. 


\section{Bibliography}

Bertness M (1989) INTRASPECIFIC COMPETITION AND FACILITATION IN A NORTHERN ACORN BARNACLE POPULATION '. Ecology 70:257-268.

Bertness M, Gaines S, Yeh S (1998) Making Mountains out of Barnacles : The Dynamics of Acorn Barnacle Hummocking. Ecology 79:1382-1394.

Carpenter S (1988) Complex Interactions in Lake Communities.

Ciotti Á, Garcia C, Jorge D (2010) Temporal and meridional variability of Satelliteestimates of surface chlorophyll concentration over the Brazilian continental shelf. Pan-American J ... 5:236-253.

Guenther M, Gonzalez-Rodriguez E, Carvalho W, et al (2008) Plankton trophic structure and particulate organic carbon production during a coastal downwelling-upwelling cycle. Mar Ecol Prog Ser 363:109-119. doi: 10.3354/meps07458

Persson L, Bengtsson J, Menge B, Power M (1995) Food Webs: Integration of Patterns \& Dynamics.

Wendt D, Johnson C (2006) Using latent effects to determine the ecological importance of dissolved organic matter to marine invertebrates. Integr Comp Biol 46:634-642. doi: 10.1093/icb/icl025

Wotton R (1988) Dissolved organic material and trophic dynamics: What is the food of filtering collectors in aquatic ecosystems? Bioscience 38:172-178. 